University of Louisville

ThinkIR: The University of Louisville's Institutional Repository

Electronic Theses and Dissertations

$5-1921$

\title{
A history of the theatre in Louisville.
}

Mary Martha Dietz

University of Louisville

Follow this and additional works at: https://ir.library.louisville.edu/etd

Part of the English Language and Literature Commons, and the Theatre History Commons

\section{Recommended Citation}

Dietz, Mary Martha, "A history of the theatre in Louisville." (1921). Electronic Theses and Dissertations. Paper 347.

https://doi.org/10.18297/etd/347

This Master's Thesis is brought to you for free and open access by ThinkIR: The University of Louisville's Institutional Repository. It has been accepted for inclusion in Electronic Theses and Dissertations by an authorized administrator of ThinkIR: The University of Louisville's Institutional Repository. This title appears here courtesy of the author, who has retained all other copyrights. For more information, please contact thinkir@louisville.edu. 
UAIVERSITY OF LOUI SVILLE.

A HISTORY OF THE THEATRE IN LOUISVILLE.

1. Desertation

Submitted to the feculty

of the Graduate School of arts and Sctences.

In Partial Rulfiliment of the

Requiremente for the Degree of

Mestor of Arts

Departimont of Shollow

hy

Hary Uaptio Diots 
4 HI TORT OF THE

THE

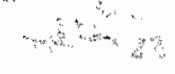

I $\mathbf{I}$

L O U I S IL L

\section{7}

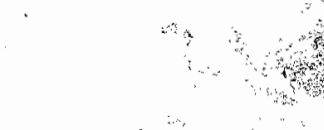




\section{A HISTORY OP THE THEATRE II LOUIVILLE.}

contrants.

Chapter 1i. Introductton.

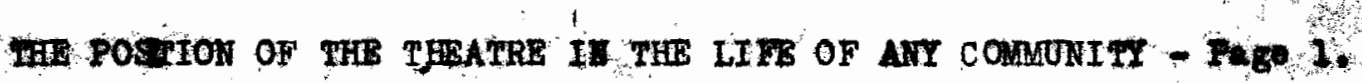
Chaptor 2.

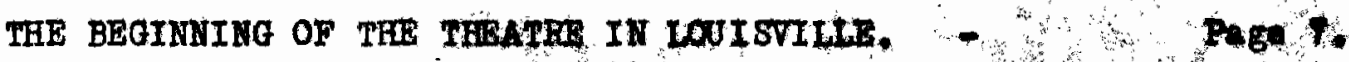
Chapter. 3.

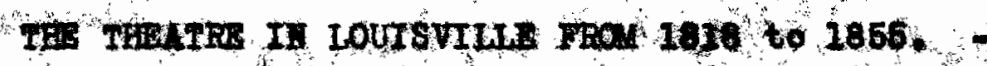

Hown

Chapter 4.

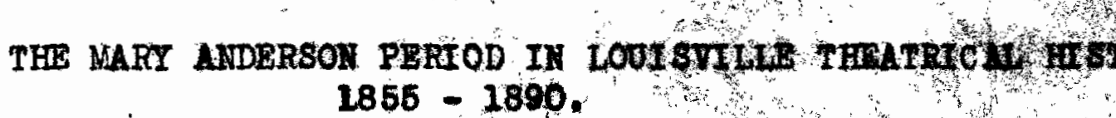

Chapter 5.

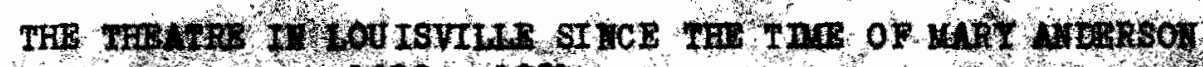
$1600-1921$

compter 6.

LOOKING TOWARD PHE HTHE.

BIBLIOGRAPE⿱亠䒑

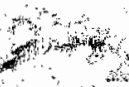
(n) 
C $R$ X $P$ I $I$

THE POSITIOI.OF IHE THEATE II THE LIF

A $\mathbf{I}$

C O M U N I T Y.

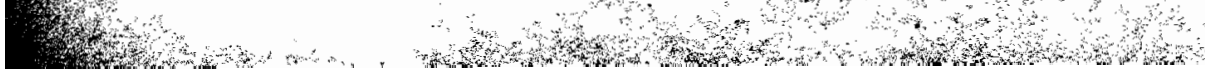

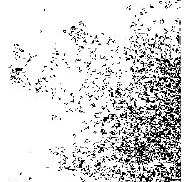

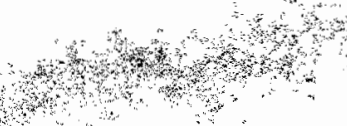




\section{CRUPTER I\%}

THE POSITION OF THE IHEATRE IN THE LIFE OF ANY COMUNITI.

$A$ ohild is considered by somo paycholoststs to pass through on Its way to manhood the tages throagh which the race bas passed on its way to civilization. If this is true of olngle man, might it not oqually be true of a comminity of men? Have not most settlements, in a groater or a 1080 degree, passed through the stages of development common to the growth of all cities unt11 they have reached the stendards of their day? A company of civilized men and women going forth to make a settlement in wer place, upon their arrival at their dectination, are firet of all cong, wed with the bare necessitles of living. They mot have food, clothing, and shelter. Then these ere found and in measure made certein of, the communty 18 ready for something more. Hehpare so formed by nature that besida bodly comfort they need mental reoredton. In tho rather primitive comminty

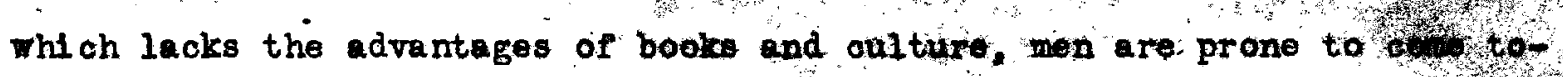
gether and provide asioement for onol other. Then their om encement, to

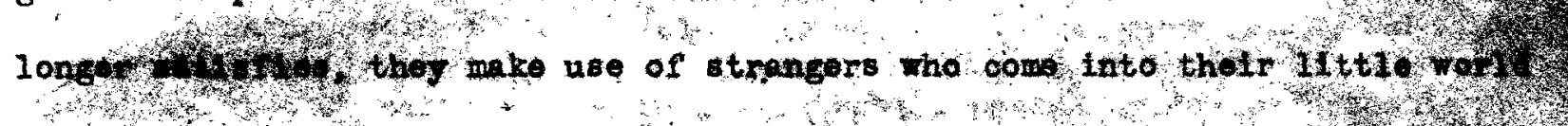
and try to porsuddo other strangers to owe to them orodualiy, thon,

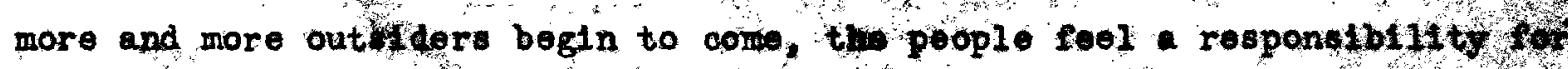

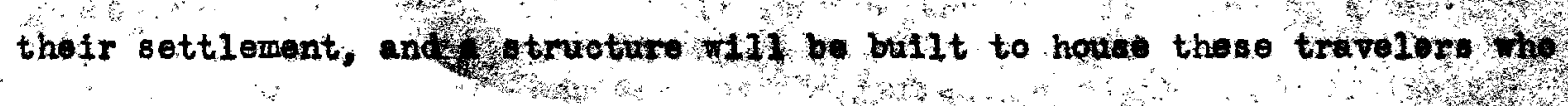

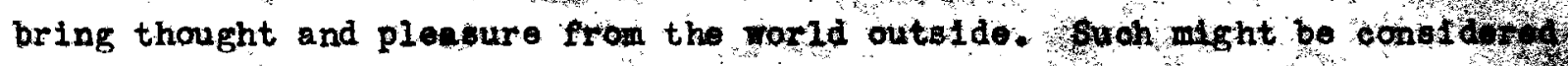

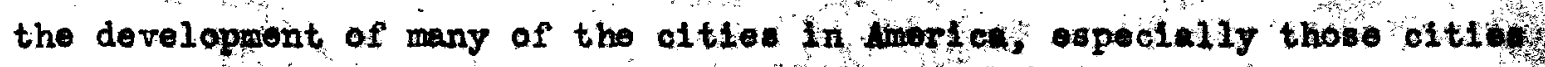

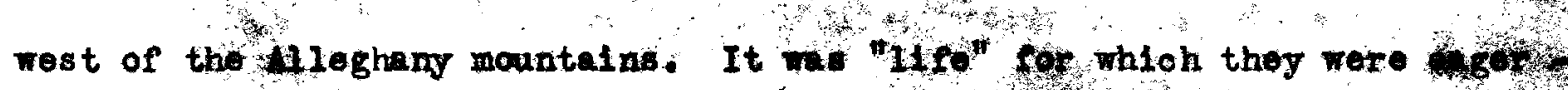

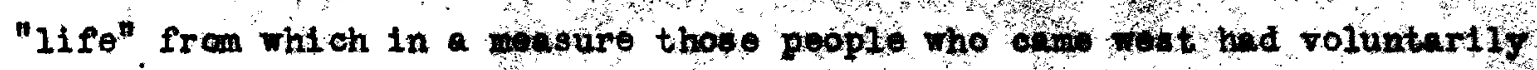

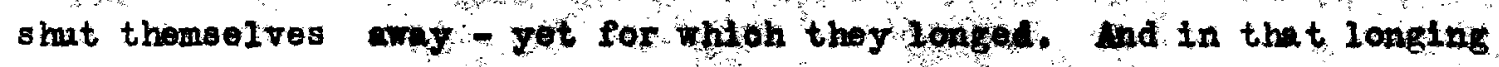
they were no different from every other nan who goes to the the tre. "The sverage spetator - daeppointed, for the monort, by his individual experience of ilving at large - ettende the thetwe in 
not so moh upon the stag a in himelf. Ho goes to the thatre - quite

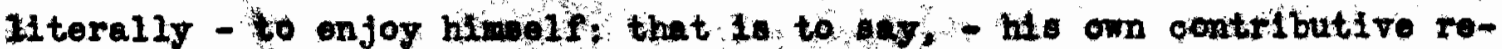
sponse of emotion and of thought. The pley mat happen to him or olvo

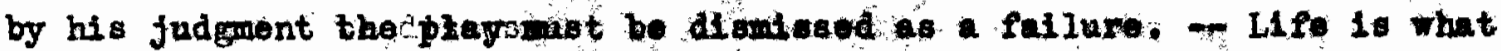
the public socks in going to tho theatro; and the appoerance, or olse the $111 u s i o n$, of 11 fe is what it veleopes and rawards in those who exert thomselves behind the footlights". (Clayton Hamilton - Seen on the StagePagen 7 and 9.)

This reaching out for 11fe, the esgeriess to feel in himself the emotions that y be affecting anethor, is natural to ma find being natural to one man, it is auro to be natural to group or a commity of men. True, there have been mon and commitles who have succeeded in suppressing their natural inclinations tomard the drama and the theatre, but the length of time durling whioh these huve boon suppressed is more matfer of years in comparison to the centurios in which those inclinations hers grom and developed.

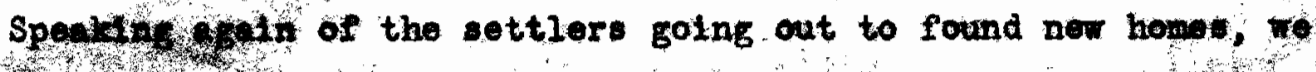

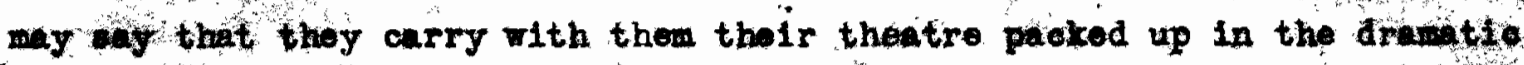
instinct which 18 thelrs by, right of birth; And it is only question of short time until that instinct will lead to the ostablishment of a theatre in which, through dram, won my see the feflection of the 1Lfe of tholt own time and that of centuries long gond.

Then, too, the thoatre beara a direot relation to public walfare and to progress. It is true that no student of the hetory of the drama or the theatre on deny that there hive been times when the theatro has sunk to the very lowest depths of dogredation. But noither can a student of history deny that thore have beon time when elvilization ftale has sunk to the dopthe of an 1morality forse than berbarian. The drat 


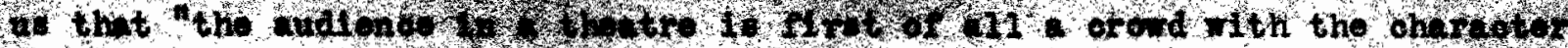

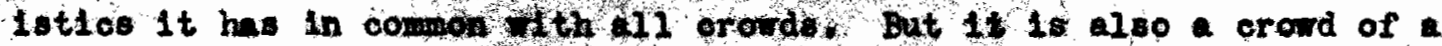
opecial type, in that it bu come togethor with the desire of recreation, of amsement, of pleasure. - A result we see that any people is 11kely to have at eny forbdy the dram that it deserves, since it can have only the kind of play the Lt lo rilling to accept." ( Hatthers - A Study. of the Dram - Pages 88 and 69. ) Thon a clase or a nation of men has degenerated morally, it required no keen logie to discover what sort of amusement that calss or race will demand. "Then the true and the beautiful in maman nature is obscuged, the true and the beeutiful in dram afes away. Hilstory confirms this stutement, and a study of the history of Iiterature makes it plainer.

Fortunately, horever, there is the other side. If it be true that When owillsation sinks; the standard of the theatro sinks with it, it is qually true and supported by historieal fact that, whon olvilivation reaches toward the heightgs; dram, (and all the arta of whioh it id a splondid composite, ) touches the heights of perfection, too. Printive as the dramatic instinct is and among the first to bo seon, yet the drame, in its hlgheth conee, 1othe last of the arts to develop. And it is in that highoet seneo, in the great plays of the peoples of history, that the arema and the theatre have had the deepest influence upon thelr ow times and ugow the times which have come after.

The Greok drame was outgrowth of the religious festivals of the gods, just as in later yoars the miracle and mystery plays grew up arownd the festival times in the chriatin church. Bven after the relation of those drames to the religious lifo had beoome less epperent, the times of their presentations were seksons of joy and pleasure. It was not only those who lived within the eities who felt the influence of those theatres. Then a play ras announced, poople from alles around came flocking to the theatre, whether it was to the great Donysin Mneatro at Athens, to the wat

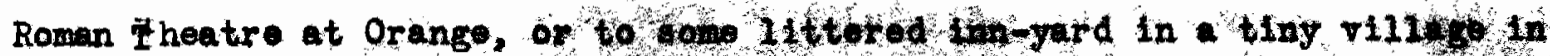




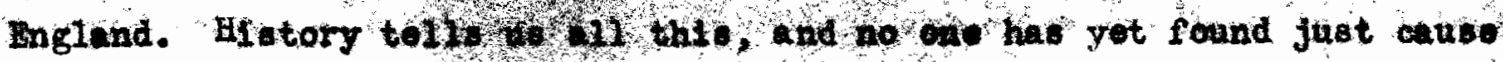
to dispute the fact that to this day the prosentation of a play ril meot with response fron porsons Ifflng far and wide. The cities or the toms of the olden days which could botst of theatre rere almost always the prosperous, thriving ones, some one ning that it was beoeuse they rere thriving and prosperoas, that they could support a theatro. That Itatement is very true, but in daye then trateling was woro diffloult than it is now, and country folk made only oconelond excursions to tow, they choos

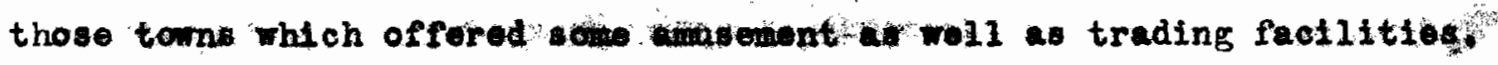
Tho theatro is alsinot cometelal aset in the life of a of by, and it is so recognized to-day, for, take it w1 in al1, the rumbental nature

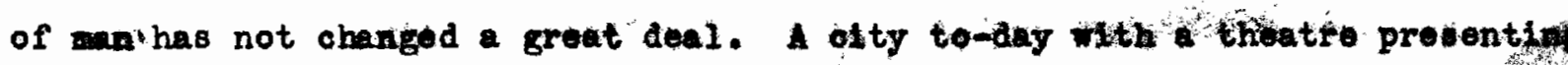
the best attractions of the day offors inducement to trevelers and to strangers to opend number of days inthin Ita 114its. There are peoplo still, cultured poople, too, who cone dnif atsintervals into the ofty to transact business. It is far more pleasnit for them to do thair buying and selling in a city which can offer pleasureble and instruotive amsement eftop

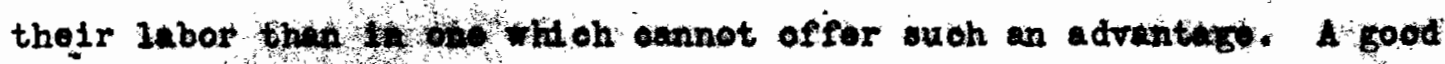
"thentre tow" his an advantuge over it sister dities with which ther obn-. not hop to compate until they can offor semo lnduoenente for ploasure and for education.

The rords, "for education", wrelgalfleant. Volumes has been writtin, and doubtlegs men more has been bpoken; about the ralue of the study of drame in education. For years poople soemed to think that the study of that particular form of 11 teriture should be conflned to the reading of playe. iEoptunately; however, there 18 greater and a greater dostre to study the great drames of hiptory, those store-houses of mighty thought and action, as they were want to be studied - to know their worth by fooling their reaction upon an audienoe in thatre. Al the masterpieces of dramatic art were de to be done ay atone ha theatre Bofore an audience, 


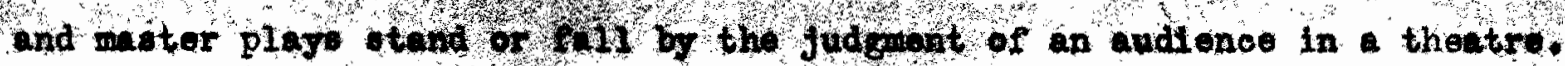

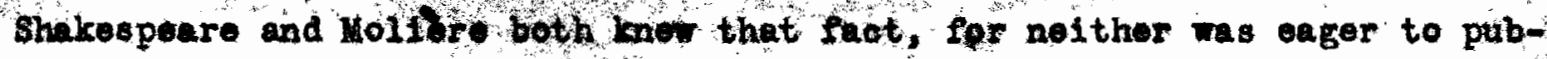
Hish his plays during his Ilfe-time. Since the atudy of the drama, then, to means of education long recognized, is it not plain that the dram, in order to do it full juatiqa, mat be studied in 1 ts propor atmosphore, the theatre?

Supported by history thich is the soundest busis upon which to make a statement, it soem oufo to ast that thore is a natural interest in the theatre, and that the theatro makes it appenrance in a comminity when that commanty has advanoel far enough beyond caring for the bare necesalties of bodily life to have time and thought to derote to pursuite of the mina. As to the relation of the theatre to pubilo melfare and to progreas, wo imagine that graph made of the history af the theatre and a graph of the progress of ofrilization would show practicaliy the seme advances and retardatione, the bame plateans.

The theatre in every age has not been 1deal, Neithor has every ago been ideal. But there are ages to which men and there are timeo in the history of the thoatre to which men may point ath pride. It 18 those wountain-tops of perfection toward which nen turn their eyes. From the deepest valiey the drellor wth the upward glence may see the star abore the $h i l l-t o p$. So men in $\mathbf{l l}$ ages have elimbed upward. iti, They have climbed far at times only to sllp back, but up again and onrard they go. The history of man coneorit the history of his institutions. The theatre is one of those institations. Hike the men who nade it, it has gono forward and slipped buok, formard and buck, Fith the surge of the conturtes. To do not judge mankind by its lowest depthe, nesther should wo judge it: institutions by their lowest depths.

Men are hungry for 11 fo - Ifo outglde themselves. Poy long for a taste of something wieh my holp them in thelr upward strugele. The rod theatre, the true one, through the turs he efored men that taste of 11 fe 
for which they aro of grotbonf mankind? Every wh has fit fults, but fortunately in most mon the good qualitios far over-belanoe the poorer oses. The theatre has its fulto and has had them through the joars, not alraya the same ones, to be sure, buts ohall we condem if for thowe then it good points so far outwelgh them? Tho star orer the hill-top has solvtinos becom very ifm to those in the valley, but in every age there are those whe will struggle on. Jfust so in the history of the theatre there heve been, and alweys 111 be, those who will fight on and up toward the dreamed-of perfootion. It is the theatres near the hoightss Which have had most influenee-for good, but one mist not forget tho lesser ones which made it possible for the great theatros to attain those helghts. Clagton Familton reminds us that Koats that we are living in "valley of soul-making." In this walley we 11te by the gospel of Truth, Beauty, and ighteousness. The theatre, in helping us to see 11 fo and to live it fuller, is an ald to help us to live more olosely cocording to that gospel. Such, as we see it, is the real postition of a true theatre in any community - to aid men to live and by that living to help others in after years to be happler. 


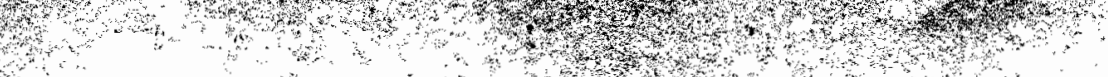

C HA P ER II.

THE, BEGINNING OF THE THEATRE

I N I 0 U. I S VI I L E. 
CENTHR 1

THE BEGINIIIC OF THE THBWHE IN LOUIS VILLE.

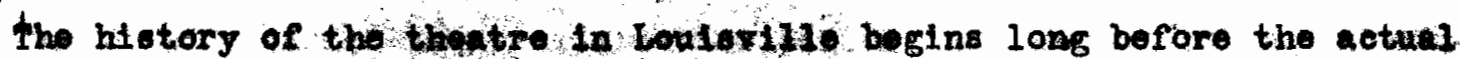

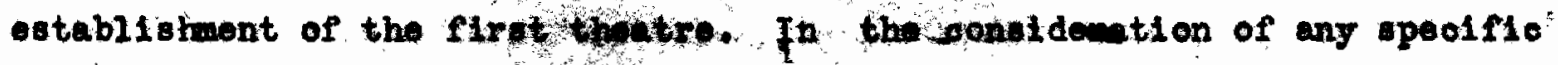
event, it is sometimes in to hive underetanding of poeoding ovents which

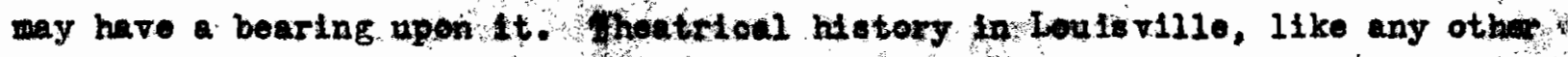
sort of history, is cloaely roluted to geography. Fad the aity hot been lockty In the part of the country in phich itway or had it, or the stato of gentucky been settied by oolonitis from another part of the land then thato

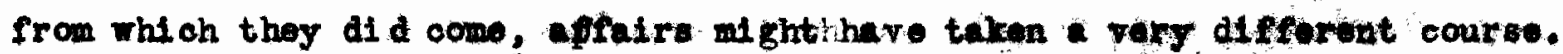

The history of the theatre ta chorlon begins in the acuthern colonies.

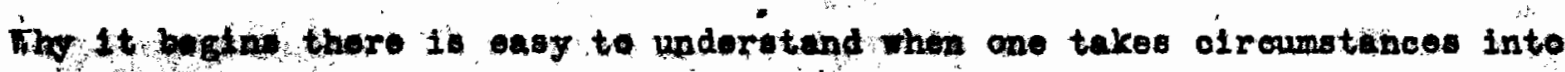
consideration. The northern colonies were eetiled by men and wonent with bittor prejudtoes agalnst pluye, pley-acting, and pley-acters, thoy had come from Fingland with those adrerse feelings, and it was many long yoars

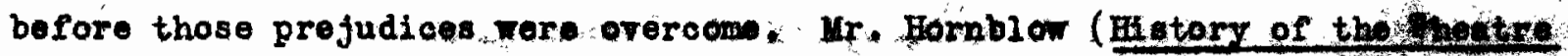

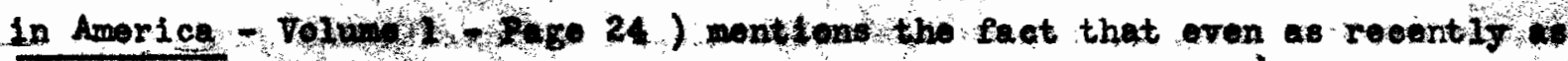

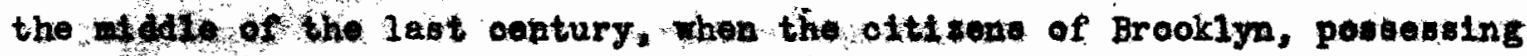
only one thoatre, were serlourly conterplating the erootion of another, the

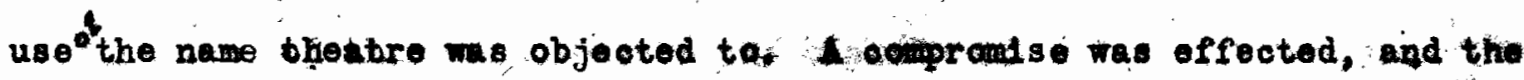
butlding wa namod the lcadong of raglow

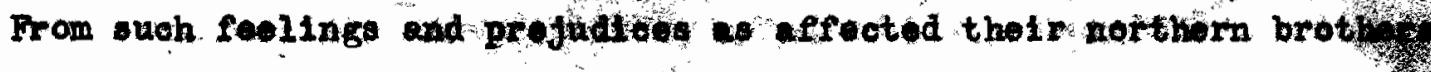
in matters of the theatz, the people of the outhorn oolonted, were, in the main, froe. They brought wth then from thole former homea, not an tt tude of hostility, but ow of frlehaliness tomard and interest in the drame. It we, thorefore, the most natural ocourrence in the rorld that Filliemsburg, Tirginia, should have the first thoatro in smorice. It was long thought that this theatre in WilMinibarg me opened with performance of that 


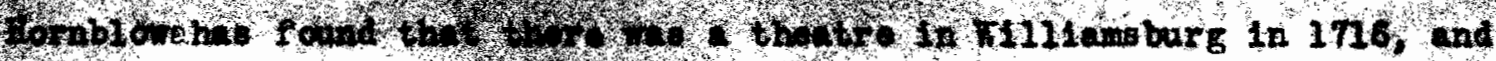

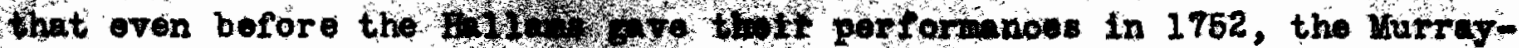
Ioen company had complet, wh toponoht thore.' Doubtless at firet, this theatre was used a grat o, 1 by mateur companies, for many such companies existed in the colonies beforotheanrrital of professional pleyers. Doubtleas, too, there were many strollytofleyer, although records epeak of but one,

a Tony Axton from Biglund, who wlolted the southon wad midle colonies at about 1730. By 1766 there wie an"Awrican Compeny" playing in Now York, end in the couth tere the "Vrginte Cewedians". Those" Virginia Comodians" played in Fililameburg, but when they went to Anapolis from Jaminy to Jun

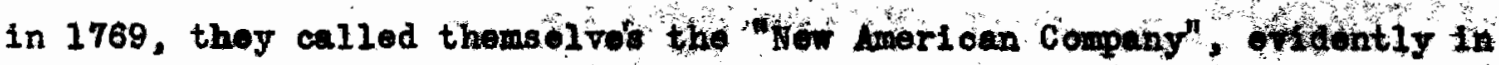
contrast to the other company then playing. Tho faot that thore wore tro compantes ongugad in prosenting plays ohous the hotivity of the theatro before the Rerolution.

During the revolutionary period the theatres were closed by an act of Congress. It is quite possible, as one writer think, that the nombers of Congress thought it necessery in those days of diffleulty to use overy means to keop the Huthty on thels side, and He mes thought to from on godlede dwoponts. Bat the settiors who ment forth from Virginia into the west at about that time folt no such four. Thes carried with them the lore for the dram and the interest in tho theatre whioh Virginia had fosterod.

The truth of this otatement 16 worhe out by the fuot that there way

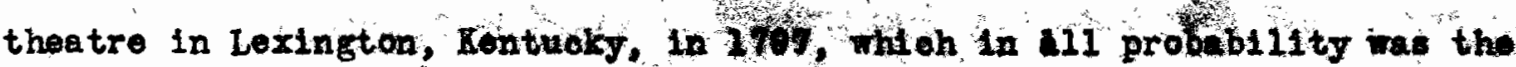
first theatre in the state. Mr. Randk (Coorge $\pi$. Rancle Elstery of Lexington (1872) - Pages 203 - 204) 1474, How Lexington supported a plece of amsement in 1797, wo aro not prepared to bay, but certainly she had ono. 'An oxhibition room, adjoinfing coleman's tavern' wís erected by Goorge Saunders and opened to the publlc, Nonday. evoning, Jphe $6 t h, 1797 . "$ in old GAZETTE says that admiseton wa sturot, and the performance bogan at dark. The price of admasion for the ptt whe throe ohilings, nine penos, 


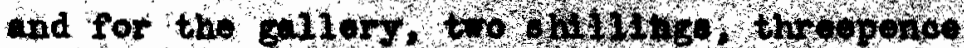
It is mown that a theatriogl performance was held in the court-houfe in Lexington in 1798 . Bvidently theatrtial business had proppored by 1807 , for in that jear, Mellish, th traveler, visited the thentre there. At that time it stood on the corner of Tater and Limostone Streots, whe distingililied gentleman, however, did not

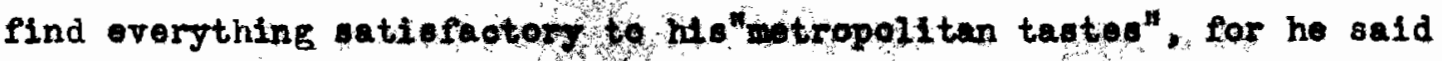

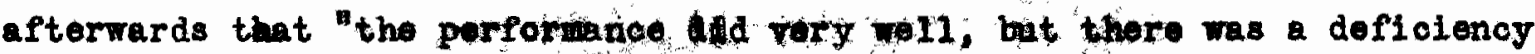
of actressess and one of the mon had to play a fomale part, which did not su1t, taste at a11."

"In 1812 MACBETH ras played at the Hotel Theatre, and on vigy 30 of samo yoar JOHN BULL, conddy, wa performd beforo packed andipnoo by Thespian emateurs belonging to tho '0ld Infantry' compay li honor of the Lexington volunteors for the war agrinst England. A goodly sum mas reallzed, and veed to buy arms, elbthing, and aap equipage for the soldiers". (Ranck -a. The theatre lled Usher's Theatre, however, is the one whtch figures most prominently in the early theetrioal hitory of Lexington and of Ientucly. It was built in 1808 by Noble Luke Usher, and tood at the corner of Spring and.Vine Stresto. It me smill, but it hed regular boxes, a plty and $a$ gallery. I. Ladion ( Dramatio Lifo hs I Found It - Page 89) says of thio thestre in 1816 that the nembers of the company in which he was playtng prom surptised to find in the principal tom of the state the poorest opeotmen of a theatre. I was informed the bulfasg hed been brewery, in whioh Me. Luke Usher, the unole of Noble L. Usher, ma once condixcted hts businese as a brever of malt liquors. The second story of this building, long and

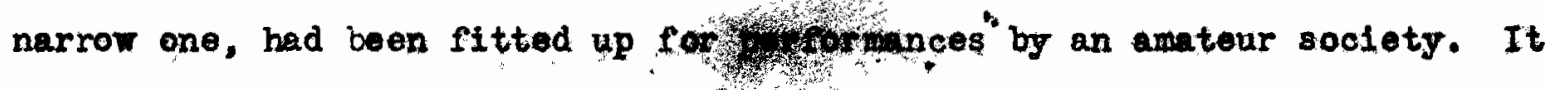
was probably seventy to eighty foet in length by about twenty-five to thirty feet in width. If I remomber rightly the tepts were contendeted upon the ampitheatre plan, - gradually rising from the noor one above the other to the back, these back seats boing renchod by sloping platform at one side. They were simply covered with canvas and palited w thout being stuffed or having backs to thom, and the burroundings, whe of the wot simplo ano 
7.

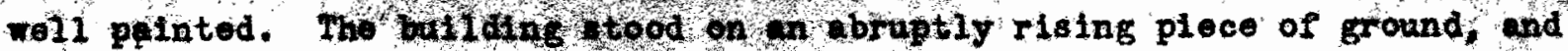
the audience entered frowa atrot newry on a level with the floor of tho second story. Adjaining this end of the baliding was room for the sale of beer and other oqually reftnod refreduments." Undermeath the stare were dresaing-rocms for the performers, into these they ontend by door opened upon a cross street. The arosildt-roone wore oufortebio enough and quite

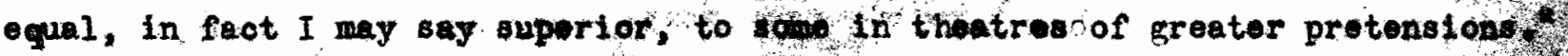

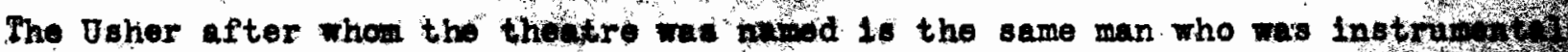
in bringing the firt rogulat company of actoro into Kentucky it. It

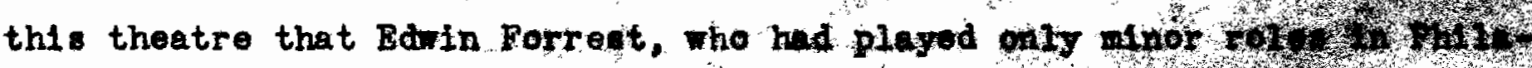

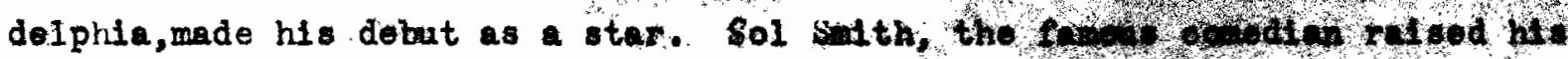
first thentrleal oompeng in Lexington, and they played for soveral woeks in - 8 the theatre there before the first bair began.

There was a we1l-ostablished theatre in Frankfort by 1814, but when a theatre was first establishod there, we beve been unable to learn. Mr. Usher doubtloss played in both Frankfort and in Lexington, for ho mentlonde

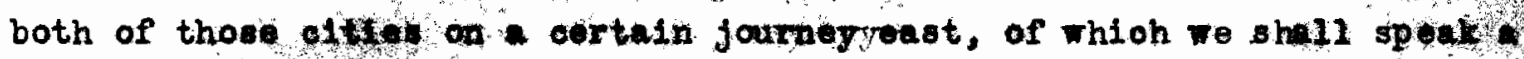
IItIo Iater.

There were several thrifling ettlerientis in Kentucky before Louisvil1e came into oxistence. It was in May, 1770, that Goorge Rogers Clarke left a body of settlers on corn Is land noter the fall of the onto. In 1780 a town named Loulorille in honor of louls XWI. was incorporated. At the time of the first consus in 1790 there fore tro bundred people IIfing there, and by 1800 the number had incfeased to three landred and fifty-nino. Many hlatorians of Loulevilie bolieve that tho population was larger wt that timo, but we are compelled to cocept the consu figures. At that time there wero four other towns in the state lerger, that lotis sille in the number of inhabitants.

One historian seys that in 180 theng there not more than one hundred

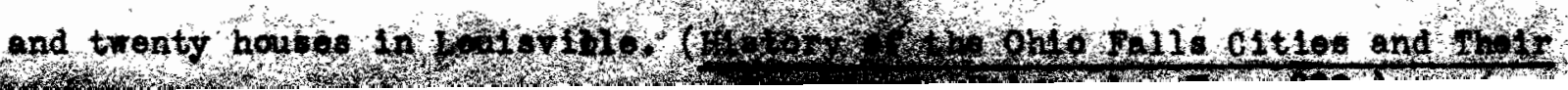




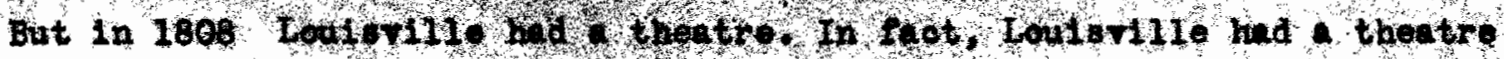
bullding befor she had a elarof bullding for the flrst church was coupleted after the earthquake in 1811. The thettre was no doubt a rather sorry and

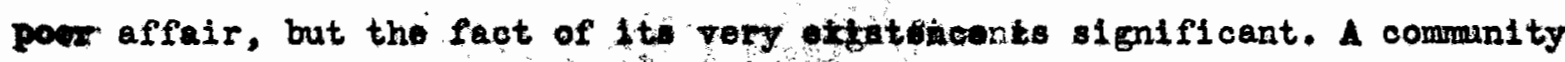
so small mat have had a very deep Interest in of desire for things dramatio oren to have cared to have theetre.

The City Theatre, for thus it res ellod, lo suppeed to have belonged to a man named Tyler (Ludiow - Dramatie life 4 I found It). It was looted on the north side of Jeffersgn stgoet between Third and Fourth Stroets. A

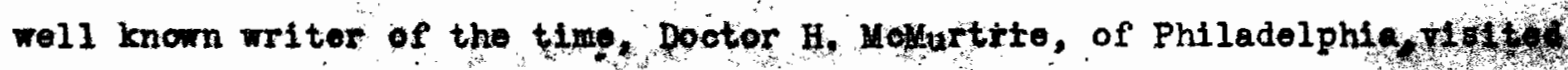

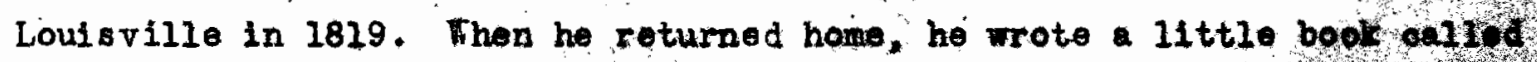

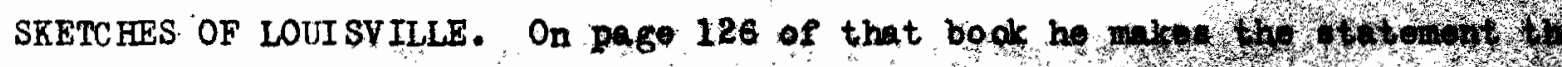
In 1819 the "theatro was a handsomo priok bullding of throe storles" bat wi" the sumer of 1818 "it was littierbatior than a barn." It is ovident from this statement that until the eppearanoe of the Drake fantily and their company, there was not a great deal of thoutrical history made in louispillo. Inference drawn from reading lowas wo to think that $\mathrm{Mr}$. Usher was at some time, connected with this thoatre well wh the one in Lexingtong

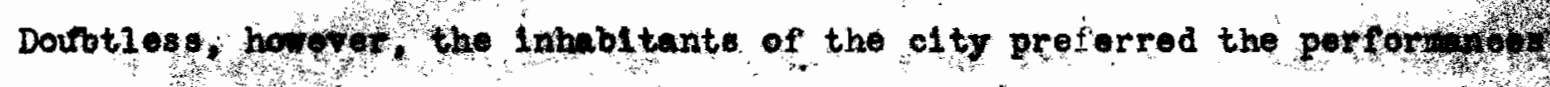
offored by otrolling companies which came doin tho river on flat-bout to those offered at the City Theatro. It 1 onld that long before the thodth was established in Louisvillo, these otroliera were in high favor and alyts. found the city a remanerative stopling pitioe.

Almost nothirg is known about the frst theatre during its ourly joard What plays were enected, or what actors eppeared there, are now long olnew forgotten. Porhaps it was used by aratours, and doubtless more than one "select concert" was given there, but this is pure conjecture, and as such it has no place in a history.

Recorded theatrical history for Loulsvilie as well as for Ientuch and for much of the west begins, not in Loulnville or eren in the rest, but fur 


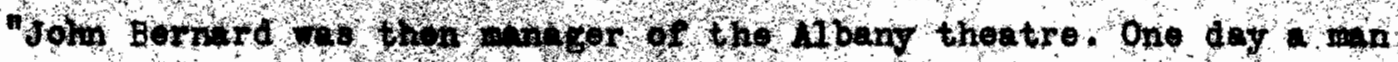
named Usher (the Jeher of the Lexington theatre) presented himelf at the theatre, stating that he we on 'actor recently arrived from the state of Kentucky.' Ho Kentuoky in those days ras Ifterally the 'far, far west', the stranger attracted more than the uoual amount of attention. He wished to play an engagenent of a fer nights, and Hr, Bornard, who had seen him act in Bouton a fer years previously, engaged him. Durligg the brief time he res with the company. Ugher told Samuel Drake, then Bernard's stage manager, that his main object in oowing east wa to try and engage a company for tont tucky, where he sald he had three theatres - one at Lexington, one at +40 fort, and a third at Loulspilio.

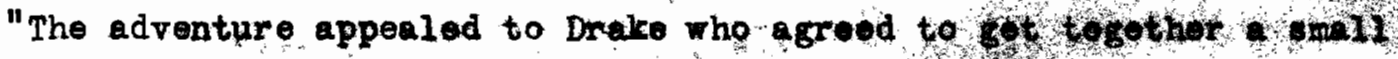
company with which he would start for Kontuchy the following spring". (Hornblow:- A History of the Theatre in Anerlca - Volume 1 - Pages 329 - 330 ).

Usher left soon after the agreement was reached, but on his way back to Kentucky he died at house on a ridge of the Alleghany mountains. Mr, Luke Usher, upon the death of his nephew, corresponded with Mr. Drake unt1l an

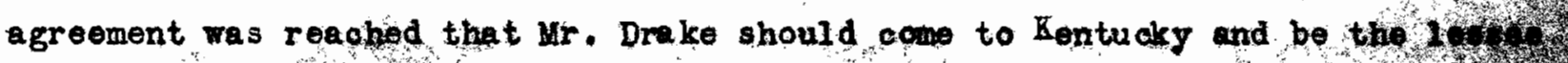
of the Lexingtong Frankfort, and Loulevilie theptres and manager then on his ow account.

But it was not,eusy matter for Drak to fulflul his agreoment. "It proved no 11 ght task to find actors and potresses courageous enough to undertake such a long, hazardous journoy thto the mknown. The difficulties of travel wero enormous, and sufflolent to deter the soutest hearted. Thero were no roads, no stage coaches, no steamers. The only methods of travel were on horseback or by wagon, and then by tow or drift boat dom the great rivers.

"Bxperienced actors, holding rell-pid, comfortable positions in the already established theatres in the esst, refused to listen to what they considered a crazy scheme, and for some time Drake was non-plutsed. Membera 


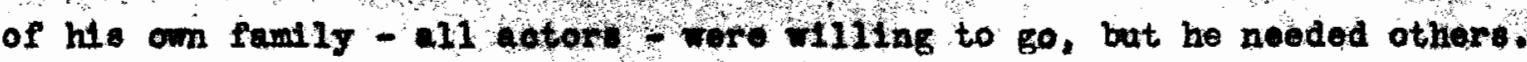
Finally he approached young actor named foah Mllier Ladlow, who had recently joined the company to plag smil parts, and made him an offor. Full of pluck and enthusiasm, onger for the adrenture, Ludlow promptly accepted and later himself became lesder enong thoes early barnstormers - Ueher, Turner, Drake, Caldrell, sol Smith, Ishorrood, Collins and Jones, Chapman Tho introduced the acted drame through the great went." (Hornblow)

It is very interesting to read in what manner that 11ttle band of pleyers arrived in Ientuoky. Drake's compeny consisted of himself (Semel Drake, Sr:), Samuel Drake, jr., Alemander, Drake, James Drake, N. K. Ludidot

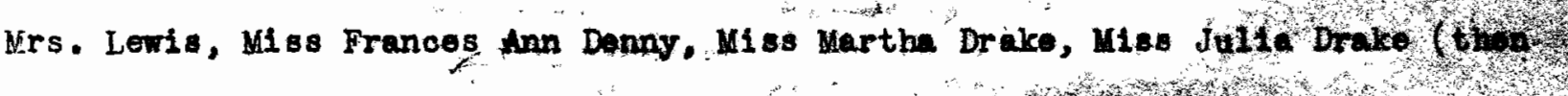

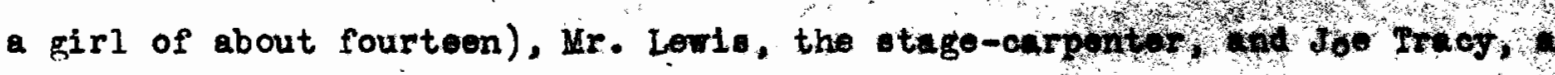
man of all work. Ludlow and Miss Denny wore both novioes. These were those who set out from Albany. They expeeted to be joined by othors in Pittsburgh. The scenery whioh they carried with them consisted of six scenes, a rood, a street, parlor, a kitohion, palace, and garden. "ehe wings, or side scenes, consisted of three of a side to be stationirt in one sense, buy fo be so arranged with elepe or aprons as to present whon roquired an out-door $\nabla /$, adapted to gortespond with garden or etreet; an infioor view, to sult partop or palace, with a third to match the uftchon. Tho prosconium was a palitod drapery made so as to be expanded or contracted to sult the dimensions 0 places occupied by our performances. These and nest drop-curtain, and green balze cerpet constitued our otugo fuollitios. The scenery could be placed or taken down and packod, in two or three bours. (Ludlow - Dramatic Life As I Found It - Page 7.)

Drake's objew was to arrive in Kentucky late in the fall, gind so he determined to perform aleng the way. Their route lay northest in liow York and then soutbrest until they hould rech the headraters of the Alloghany Rivr. They wore to prooedd thenee to Pittsburgh by boat and wot: there until time to leave so that tho company could arrive when the kentucks 


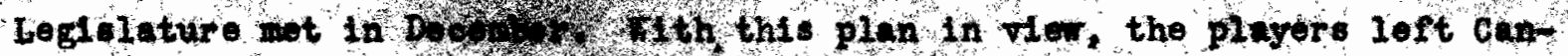
adaugan, in northrestern toutork, in the latter part of July, 2825. They possessed a road wagon with tro horees and a light spring wagon dram by one horse. Mr. Drake omed the road ragon and horses, and to Mr. Lewis belonged the other carriage. Mr. Drake was scwewhat fleshy, and he was also the oldest member of the party, so he often zodide with Joe Traoy in the larger wagon. Mr. Lewis and hls wife and oocasionally one other lady rode in the sprins wagon. The others valked.

Then they arrited in Olean, at the houdraters of the Alleghany, they sold their horses and magons, and invested in a flat-bottom boat of the typo lmown as an "ark" or a "broadhorn." "The boat was boout twenty-five feet long by fifteen feet wide, bonrded up the sides and poroded with an elliptical nefout high enough to allow man of modium statura to atend erect beneath the centre. It was quadrangular, and intended to be a kind of floating house of small dimensions. In one end of this boat were two rooms. partitioned off as bedroors, one for Mr. and Mrw. Lewis, the other for the three single young ladies, the Misses Drake, and Miss Denny. The men, especially, the young ones, were expected to 'rough it', and rough it wo did." (Ludlow - Page 17.)

The trip on the riat-boat was rery unpleasant, for the sun beat down, and there seemed to be little moans of protettion from the hoat. The ledies complained that it was excoedingly wern under the low roof, and flnally' kind of canvas sheltor was rtggod up from piece of scenery so that they might sit on deck, enjoy the breezes, and yet be protected from the sun. After this arrangement was made the ladies were far more comfortable. The country through which they passed was very wid until they neared the region surrounding Pittsburgh. At night they could heer wolves howling in the woods near the shore. It was their custom to tio the boat up at night, and the ladies and the older men slept on 1t. The young men found lodgings whenowh they could in farmhouses, and when thoh quarters could not be found, thoy siopt in bank. They procured thoir provithons from the farmens along the 


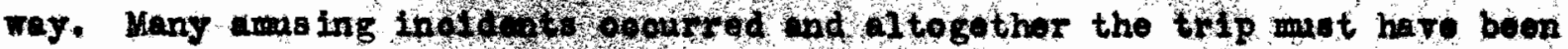
something of a lark for the rounger wombers of the party. At length they arrived in Plttsburgh and beghpleying thore about the middio of lagust, 1816. The season at Plttsburgh ondud early in Noromber with a bonefit for Mr. Drake, Sr., and they wererready to wake the journey to thair next stopping place, Franffort, four mundred miles amay. They flocted down the Ohio River in another of the beosdhorns as far is Maystille, whohat that time was called Limeetone, Thoy arrived there about November 22, 1815. The romainder of the fourney to Franfort was made in two wagons. One wagon was for the ladies, the other for the soenery. The gentlemen evidently: Iade their journey on foot as before.

In Frankfort they wore fqined by soverel other ootors, John Vaughan, leading man, Eenry Vaughan, Frank BIlesett, who playod low comedy, Tom Jeffereor - ldest son of Joseph Jefferson the firat, and James Douglass, a son of David Douglass, who is fanous as one of the earliest theatre managers in the hilstory of America.

The first real theetrical season in Kentucky began in Frankfort early in December. 1945. The pley preserted pers ThounTAINEERS by Colman.

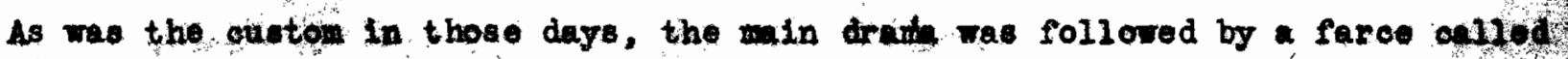
the ROOR SOLDIER, Mt. Bl1ssett played Bagatelis in the farce and "ho was gredte In Frankfort the players were partioularly welcomed by Judge Ceorge M. Bibb, Mr. Marshall (one of the two of that name who wore prominent in Franifort) and $\mathrm{Mr}$. WIIlis Lee, The season lated unt1l early in March, 1816, when the players left for Loulsp1110.

"Our Prankfort season closed, I have already said, about the ftret of March, 1816: and we started for Loulovillo, being fourney of about fifty wles. There were no railreadsacecopdations betwoen the two towns in those days, and I do not recollect that there was oven a line of stages; 80 we prowred private conveyances, and rero two days in making the transit. On arniting In Lout 81110 we found the people on the tiptoe of expectation, and 


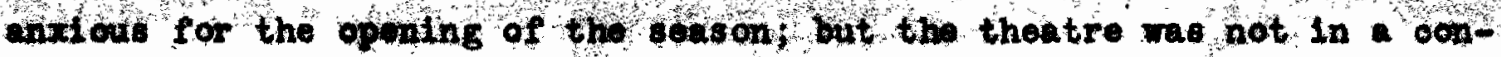
dition to be occupled; it was dark, dingy, and alrty. The foenery mo badiy painted; the auditorium done in the woat dismal colors, and the house badly provided with the means for lighting $1 t$. "Tho first matters to be attended to wore the removal of those weightly objects. There was a man 11 fing at tha't time in Louistille of the nawe of John Hos, house and sign painter, who had a tolerably good taste, and some okill in soono-jinting. He was employed to repaint and improve the appenrance of the audience part of the house, while Mr. Drake, $\mathrm{Sr}$, and his son Aleck went to work to change the aspect of the scenery. In

"In about two foeks the theatre had been got into panable condition for the opening, and we comenced our season with calmans oowdy of the HEIR AT LN, and the comic opera of SPRIGS OF LAUREL. In the comedy the principel characters were filled as follows: Doctor Pangloss, Mr. Blisacty Lord Duberly, Mr. Drake; Diak Dowlass, Sem Drake; Zekiel Homespun, Mlode Drake; Kenrick, N. M. Ludlow; Lady Duberly, Mrs. Lewis; Cecily Homespun, Miss Denny; Caroline Dromer, Miss M. Drake, In the farce Mr. A. Drake played Nipperin. In ths character ho wo facsimile of Mr. Joln Bernard, the late maneger of the Albang Theitre, who in turn was atd 6 a copy of the celebrated Edwin, of London. The performance went off $u$ th great applause, and the people appeared dellgbted with the company.

"The only theatre in Loui oville at that timo stood on' Jefferved Stroot, where it was in 1832. It wes afterwards burned dom. It belodg, I bellete to a gentleman of the name of fyler. This season of ours. in Louisv1110. I understood to be the first that had been made by any roguly company of comediens. It lasted about ten or eloven weeks, and was undoubtilily profltable to the management, for the house was well fllled every night. The season closed with benefite for the company, all of then being well attended, and this in town of not than three thoueand 


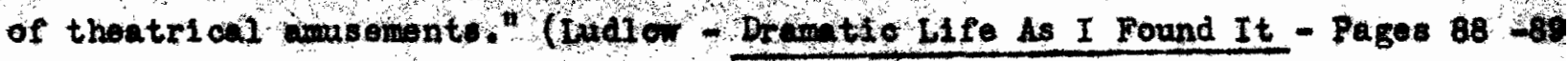

Then they had finiehed their seavon in Louloville, the company departed for Lexington.

Thus was the history of the theatre began in Louisvillo. The Mr. Samuel Drake who was the head of the company, was the one who was destined for the next ten or fifteen years to control the theatrical progress of Louisville. 
C H P T E R. III.

\section{THE THEATRE I H LOUISVILIE TROM $1818-2865$.}




\section{CHAPTER III.}

\section{PHE THEATRE IN LOUI SVILLE FROM 1818 to 1855.}

After the season of 1816 in Lexington, the Drake Company followed practically the same round of engagements as those of the year previous. Frankfort was visited in the winter, and they arrived to open the secend season in Louisville bout April 1, 1817. Thile in Lou isville the company was joined by an actor named Aaron J. Phillips who played an engagement of six nights in such characters as Othello, Richard,III., and Macbeth. Mr. Ludlow remarked that hir. Phillips was an actor of no great excellence, but passable in his general preformances. This was probably the first advent of a so-called star in Louisville. There was nothing particularly notable about this second season which lasted until about the last of May. The benefits of Niss Denny and Mr. Ludlow were the most remunerative, and this fact was the result of their exemplary conduct while in the city. The people regarded them as an excellent lady and a gentleman, as well as good players, and signified their approval by supporting their benefits liberally.

At the end of the season of 1817 Ludlow and Vaughan left Mir. Drake's company and set out for themselves, visiting Nashville, Huntsville, St. Louis, and New Orleans, and afterwards, except at intervals, working separately from the Drake players.

Mr. Drake found the field most to his liking in Kentucky, and he, confined his labors to thet state except when he took his company to st. Louis, to Nashrille, to Cincinnati, as he did in 1819, 1822, and 1829.

In Louisville Mr. Drake came into control of the City Theatre in 1818, and later it became his property. He remodeled he building so that when Doctor MoMurtrie visited the city in 1819, he found the the theatre "a handsome brick building of three stories." Until the summer of 1818, "it was but little better than a barn. At that time time, however, 
It underwent considerabie alterations and lo now fitted up with a degree of taste that does honor to its manager, Mr. Drake, whose unceasing endeavors to merit the approbation of the public will no doubt meet with a liberal recompense, in 1ts patronage. The house is divided fnto a pit, two tiers of boxes, and a gallery, capablo of containing in all about oight hundred perons. Attached to the premises are retiring room for the 1 adias, and one containing refreshents for the company in general." (Molurtite - Sketches of Louisvi110 (1819) - Page 126)

Colonel John Thompson Gray whose recollection extended back to 1825 gave to Mr. J. Stoddard Johnison the following information regarding the theatre as he remembered it. "Drake's old Louisvilile theatre was a very creditable one, and had some features not excelled bytits successors. It had a row of private boxes occupying the whole front of what is now the dress circle, as in the French Opera House in Ner Orleans. They were closed in the rear, having doors fon entrance and open in the front. The sedond tier was open and corresponded to the latter day dress circle, while the third ras low priced as now. The pit was not the cholce place, as now, but was occupled by men, veteran theatre-goers, and critics. The theatre was lighted with a grand chandelier swang from the dome, "and with side lights, all of sperm candles. And there was never a dripping candlo. This was in keoping with all of Drake's appointments, the decorations of the theatre being in harmonlous colors and every adjunct tastefully adjusted.

" 'old Drake', as he was familiarly known, took a steady hand in the play in parts not of the kind requiring mach histrionic ability, as in the King in HAMLET, and in such characters as showed off his fine figure and hts gorgeous make-up. He was a fine fencer, and the audience was never so, much pleased as in a combat with swords botwoen him and the elder Booth, father of Edwin ard John Filkes. The two were great friends, and Booth spent much of his time with Drake at his auburban home on the river road." ( J. Stodiard Johnston - Memorial History of Louinville - Volume 2 - Page 329.) 


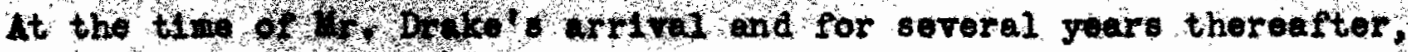

- Loulsville was under the gutdanes of the Kentucky Trustees. "The trustees wre protty rigld in the oollection of taxes, and now and then tried to shame delinquents into paymett by advertieing them in the newapapers. There was one citizen, however, with whow they never quarroled about his taxes, though wo very rarely paid any tax in money. Thte wa Samuel Drake, the proprietor of the theatre. Drake was a doolal compenion, besides boing a fine actor, and now and then gave benefits instead of paying in money the license required of htm as a shownan. The first of these benefits was given for the town in 1817 , but they were aftermard given for whatever charity the trustees agreed on. In 1824 they had become quite numerous and were given for the Greeks, for dratning the ponds in the town, for the orine hospital, and for the charohes. Drake usually gave the benefits when the season was dull, and was probably a gainer instead of a loser by them." (Johnston-Memorial History of Louis ville Volume 1 - page 64.)

This fact about the taxes shows how Mr. Drake not only pald hil debtis to the city, but gained patronage and respeot for his theatre. He seon to have been a far-seolng and wise manager in a great many respeots, and the people of the ofty reaponded to his efforts to give them the best that he could

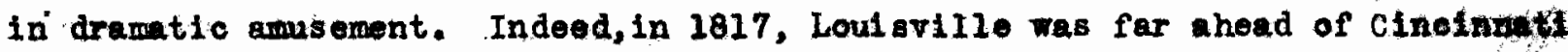
in hor interest in. the theatre. Ludlow montions this fact, saying, that in 1817 Cincinnati, a city of at leest oight thowound inhabitants at that tino; "could not or would not afford a proper oncourkgement to an intellectual amsement whioh in Lexington, Loulsville, Nashille (each of those towns not having half the population of Cincinnat1) mot with liberal encouragement." (Page 116.Dramatic Life is I Foand It.)

The information regarding those early seasons at the theatre is unfortunately meagre. Ludlor's book, DRAMATIC LIFI AS I FOUND IT, which he published in 1880, contains numerous references to the theatre in Louis ille, but after Ludlow lef't Drake's company in 2817 , it is only occasionally that 


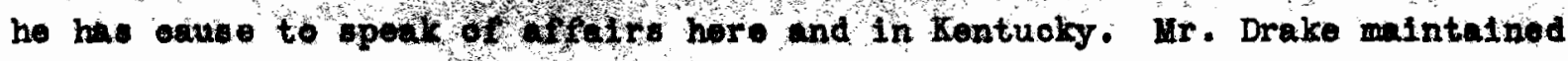

a clout in the kentioky thotres, notibiy those in Loulsville, Lexington, and Frankfort, and onee $\mathrm{In}$ amile, betwoen seasons at those theatres, ho and his company would joumes to other eftles such as Cincinnat1, St. Loula, and Nesholile already mentioned.

In 1819 - $1820 \mathrm{Mr}$. Drake' company we made up of eight men and five women. The men wore Mr. Samiel Drake, Sr., Sawal Drake, Jr., Alex Drake, Palmer Fisher, Henry Lew1s, James 0 . Lewly; James Douglas, and a property man. The ladies were Miss Denny, Mid Julla Drake, Mrs. Fisher, Mrs, Leris, and Mrs. Nongin. This was the company he took to St. Louidiwith him where Mr. and Mrs. Iudlow engaged to pley wih him and return to Loulsvillo. Hrake and Ludlow, however, had difflculties concerning the acting arrangements for Mrs. Ludlow, and the Ludlows left the company before they reached Loulsville. On the way there, de part of the company remaindd to play for a few weeks at Vincennes, Indiana. There, whlo swiming in the Kabash River, Mr, Jawes Doug1as, a member of the company, was droimed.

The great Edwin Forrest in 1822 was just at the beginning of hte professional cerewo, ind when he appeared In Loulsville in that year he was not the fawous parson who played there in 1839 as spartacus in the GLATATOR and as Ing Lear. Forrest's carser the beginning was not so bright as to 10ud persons to think that he rould become the great star he later wes. In Louf stille in 1822 he played, or "attempted to pley", OTHELLo, and an an instance of the taste which Forrest displayed in the beginning for low comedy, he played the part of a negro dandy upon that first visit to this city. One season followed another with the stook company playing and with the visits of suoh stars as would brave the dangers of the far west, and with Mr. Drake' always continuing the manegement of the city Theatrey accasionally permitting one of his sons to take his place.

At some time during one of the sensons of about 1828 or $1829 \mathrm{Mr}$. Thomas D. RIce was a nomber of the prake took pompany. It was hot thon as wil knom 
as ho later became after homd oung ond throod Jumping Jim Crow, from.

which he earned his neile fim Crow Rloe, It was during this season in Lou invili that Mr. Rice first played his character of Jim Crow, and it was from on old Louisville negro that he copled the character. As the story goes, the orlginal Jim Crow was an old sIave tho belonged to Mr. Crow who kept a livery stable beck of the theatre, and the save naturally called himself by hi: master's neme. It was his particular derty to clean and rub'down the horses in the rear yard of the stable. One spring dey ur. Rice was standing at a back door of the theatro watching the old nogto and listening to the song old Jim san as he worked. E. S. Connor says that the negro "was much deforwed, the right shoulder being arawn high up; the left log stiff and crooked at the kneo, giving him a painful but 2aughable Iimp." (E. S. Connor - Bow York Times, Junt 5, 1881.$)$ As the negoo worked he sang a sad sort of tune, almost a croon, and at the ond of each rerse he gave a queer little jum, and when he came down he set his "heel-e-rockin"". He celled this performance "Jumping Jim Crow" The words of the refrain as given by conner are:

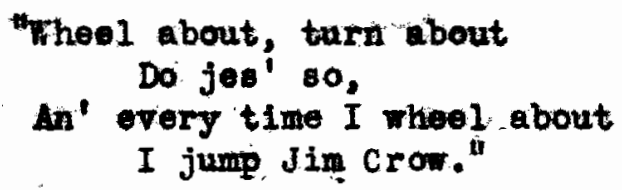

Rice listened to the old negro for several days, and finally he went to thy 01 sleve and paid him to sing the song over and over, and the actor learned 1t. About that time, Mr. Drake was producing a 1ittle local drama called THE RIFLE, and Rloe was cast for the pattodf a Kentucky corafield negro. He asked Mr. Drake if he might Insert the Jim Crow song, and Mr. Brake reluctantly consented. Rice made himself up to look like old Jim, he sang his song, and afd his queer little dence. The audience went wild. It is said that he was recalled traty times on the first night. The piece, whioh would probably have been a flat failure, ran for many nights to crowded housed. Ever after that Thomas D. RI00 was knom Jim Crow Rice, and even as late as in the fonties ho was atill playing Jim Crow along with other negro imtations. The groat Jospph Jefferson began his dramat10 cureer at the age of four, as. 


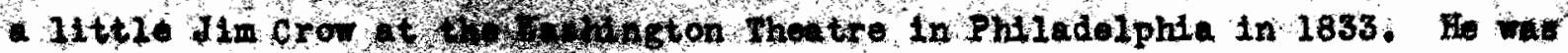

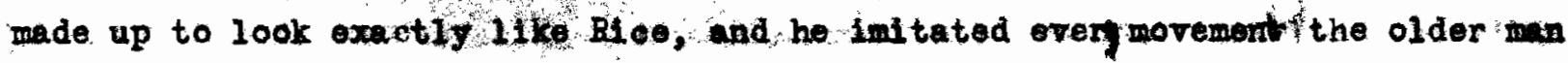
made.

In 1829 besides the ctty Theatre, there the erscted a temporary theatre which served for a couple ef censons, Ur. H. I. Ludlow th Mr. J. Furdy Brown, a popular clrcus manger of that time, hed the ballating erected. Ihis structure was located on fefferson etreet not far from Drake's theatre, and it stood on a corner. Hr. Ludion hinielf was not certain as to the location, but remembered that it was about three or four hundred foet away from the older theatre. The building was sough, but substantial affalr, and wade so that it would be sultable for efther dramatic or equestrian performuces. As it developed only dramatic entertainment, were given there, for fir. Boow and ur. Indlow hal a disagreement, and Boom did not como to Louisville at that time, and the theatre bullding remained as Ladlow's ohare of the partinership.

On June 22,1829, Mr. Ludlon opened the theatre with that fine old comedy, THE HONEYNOON, and farce called the RENDEZVOUS. The second night the ontertainments were THE STRAMGER and the farce? THE LIAR. Some of tho bear bers of the company beatdes Mr. and Mrs. Ladlor were C. B. Parsons, F. Mocerfort Mrs. Moclare, Wis Dunhan, J. E. Tatsoñ, and I. S. puncan. Tho season was verty

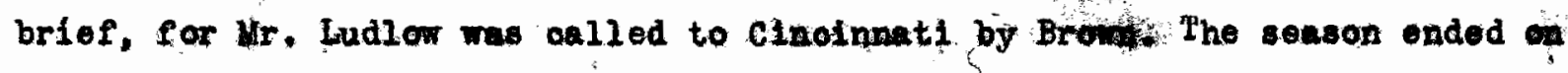
the fourth of July with M. Hoh' "national dran", SHR TOOLD BE A SOLDTER or The Pieins of Chippera, and the feros, REVIE,

After the seas on in Cincinnuti ended, Ludlow returned to Louis 1110 , and in the temporery thentre bullatng on Octeber 5, 1829, ho began he

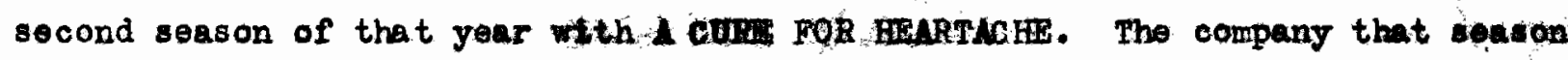
consisted of N. M. Ludlor, A. T. Jackon, J. B. Katton, H. H. Barry, T. MeCafa ferty, E. S."Duncan, C. F. MoC Iure, Ur. Cenbridge, A. Bgbert, J. Scott, H. Kook ford; Mrs. Ludlow, Mres Mchlure, Mrs. Jadkon, Mispounham, Mi ss Rowe, Mts Petrle, Mrs. Edstrum, End Palmo, and Charles B. Parsons. Mr. Parsons 1ater became minister in the Hethodiat apingopel okaroh, and wes pastor of the 


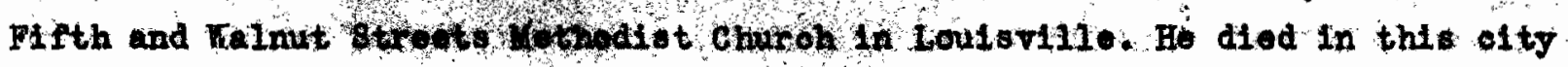
In 1871. Mr. Ludlow Exys that ho was preacher when an actor and an ator when preacher. Mr.Parsons left Ludiow's company at the end of that season and was ongaged to play in Drake's clroult of Kentucky theatres. At one time he was stage and business manker for Ur. Drake. He maried a Miss Oldham of Louisville.

Although the performancesor tho first and second nights of the season: were well attended, the manager was not satifefied; and so he billed Mrs.Hownd in some operatic pieces such is ROB ROY, GUY MANMERING, and the DEVIL'S BRTDAR. The press critlcised Mr. Howard's voloo, $L^{\prime r}$ saying that it was not what it had beon, and such criticism was not very conducive to large audiences at the thoatr Just as Mr. Howard was fintuhing hls engagoment Mr. Thomas B. Hamblin came to the city on his first visit to the west. Ludlow wished to give the people of Louistille the advantage of all the best talenfthat came its way, and so he engaged Hamblin at an exorbitant price, or at what seemed to bo exorbitaht - that is, six nights and a benefit on the serenth besides one- half of the receipts of each night. The theatre held, at its fullest, only abont four hundred people and the adaision was only gerenty-fite and fifty cente, so that it is easy to reo. why the price mas somewhet excessive. Mr. Hamblin's engagement war most successful one, however, and he played the leading parts In VIEGINIUS, MERCHANT OF VENICE, MILLIAM TELI, HAMET, RICHARD III, JULIUS CAESAR, and DAMON AND PYTHIS to orowded and rell-pleased houses. Several years later Mr. Heablin we the manager of the Bowery Thettre in New York. Following Mr. Bamblin came the English $10 \mathrm{w}$ comedian Joseph cowell. He had been performing cincinnati. with ir. Drake's company wht oh wes there during the season Mr. Iudlow was in Louistille. He had with him his nine year old son, Sam, who proved even a greater attraction than hil father, for the child was really very clever. He sang comb songs in the comedies in. which his father played. Cowell himall me fine comedian, and he vistted 


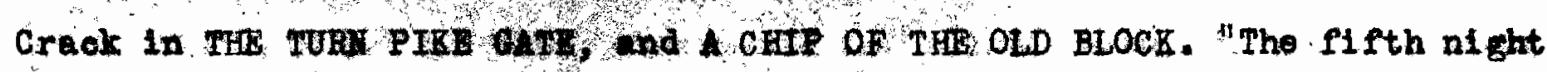

was put up for San's benefit, when performed for the first piece the HONEST THIEVES with Joe Comell as Abel Day. This was followed by a song by Mr. John Still (the vocalist of the company), and then came a farre called the \$100 NOTE with two Billy Blacks, by the comells, father and son, personating scenes of the piece alternately, - one ppopping on the stage when the other went off. It was outragebos absurd and unprecedented, but was funny, rever theless, and the eudience seemed to enjoy the jokes and conundrums of each. The piece olosed pleasantly. As the curtuln as about to fall at the ending of the piece sam (the little fellow) rushed dom to the footlights, saying to the audience, 'Thy is this farce like stiok of candy? Do you give it up? Because it's sweet thing, and you've had the short and the long of it', pointing first to himself and then to his father. The house was convulsed with leughter, and the performers standing in the rear of Sam veee compelled to make a quick retreat behind the seenes to woid all the pieces of coin that wer! pitched and harled on the stage from all parte of the house. Among them were gold pieces, which of themselver mounted to thiety-five dollars. The generous Kentucklans Fere dellghted with the boy." (ladlow - page 357.)

Follownt the Comells came Mr. Edward Raymond. $\mathrm{H}_{\mathrm{i}}$ s opeaingeplay was FILIIM TELL Given on November 16, 1829. Following that he played BRUTUS or the Fall of Parquet, PIZARRO, and ROB ROY.

Then came Mlle. Celine Celeste, the French actress and danserse. At the time of this trip to Louispille HIle. Celeste know but rep little English, and her performances were limited to pantominies and to dances. we lady evidently possessed a great deal of dramatic talent which somed It her pantomime, and the fact that she wa able to hold audiences fascinated without speaking shows a great deal of ability. Ludlow sald that when sho appeared in Louisville we was exquisitily beautiful and as "lithe as a farn." Hornblow attests the faot that although sho mow no English at first, her groos and beauty drev adintration. 


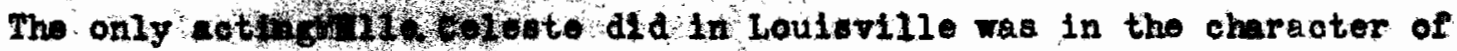
Myrti110 in the drame onlla the BROKBN STORD. 'Myrt1110 was a dumb boy, and he did not have a word to say until the closing 8 cene of the play when he had suddenly to recover hil opeooh and cry, "The murderer of my father!" In the plot of the piece it seems that the boy lost his power of speech when he was very young beanse of the shock of seelng his father murdered. Years later when he is grom to manhood, he mots the man, and in the stress of excitement cries out the worde. It ars a very good part for an expert pantominiet like celeste, but eren the flve words of finglsih were too mach for her to manage, and inated of the line whioh she was reguired to say, she cried out "Murder mon pere!." as shatelied the maderer in a wild manner. The offoct. was so comic that the ourtain usually fell with a good laugh from the audience. "During those nights the lady did some very admirable dancing, that quite surpirsed the Loutotille people, espocially those that had not witnessed any French dancing; yot it was rather repulsive to the stald ladies who had not been in the babit of seeing females kick up their hoels quite so high in their dancing." Eut such a feeling toward the dancing was soon forgotten.

The year wa not very favorabie one for the manager, and he olosed his season bout the flrat of April, i830, and went ith his company to Cincinnat1 and later to Pittsburgh. One reason for the laok of success was the extremely cold weather, and the theatre, not being ballt in the most weatherprobf fashion, wa prictically impossible to heat. The performances were given only occasionally, and then they were not well attended.

During the season of 1830 and 1831 Drake ras again in Louisille with h1 s company, but when, in lovember, 1881, he took his troupe to Frankfort for the usual winter season there, Ludlow, acting under the instructions of Jamos H. Caldwell, the New Orleans theatre manager, brought his company to the City Theatre in Louisville for a season. Mr. Ludlon had been playing in NashVille, and the company which came to Louisville with him from there consisted of John Gilbert, E. s. Conner, C.F, Ueclure, J. E. Hatson, A. J. Marks, Fillian 
MeCafferty; Robort wrrel1, howry Schooloraft, B. S. Dancan, I. Baldwin, Geodge T. Rowe, Mrs, Judbur, Mrs. Moclure, Mra, Rowe, Mrs. Vos, Mrs, Marks, and Miss Vos.

The Loulsville season opened on Thursday, November 17, 1831, with the comedy LAUGH WHEN TOO CAN which was followed by the farce T'liAS I. The audiences were very smll first, and the first goed house the players had was on the following Monday, November 21, when Louistille for the first time saw RIP VAN WINKLE pleyed. Gharles B. Parsons is conoldered by Mr, Ludlow to have been the first representative of RIp Van FInkle whom the stage knew. At any rate, he was the first Rip west of the Alzeghanies. James H. Hackett first produced the play in Ner York in Apri1, 1830, but Parsons had acted the character six mont hs previously in Cincinnati. However that may be, Loulstille had her first sight of Rip Van Finkie in 1831, and thereafter she saw many impersonations of the oharacter unill years later Joeeph Jefferson made it his own.

One of the performers during that season was Thones D. Rice, and Jim Crom was doubtloss as popular as he had been several years bofore. James Thorne, an Englieh actor who mpeared for many years in the theatres of America, mule his irst apperance in Louls villo in the course of the season of 1831 - 32. From a referenoe in a letter writton by Jamos H. Fackett and published in an old paper of 1846, 1t is known that ho appeared in the city in 1832, but ho mat have plegred an engagenont with $\mathrm{Mr}$. Drake, for Ludior does not mention him. The season lasted about eleven weeks and ended on Saturday, February 3, 1832, when the coapany left for Cincianati, and Mr. Drake returned from Frankfort.

On May 7, 1832, Ludlow was back egain at the city Theatre with his company where they opened with the comedy, PAUL PRY, and the farce, THR IIAR. Ludlor himself played the loading parts in both pieces. The second night the engagement of George Holland, the flue Bnglish comedian, began, and he played for two weeks to very remmerative houses and establiohed himself as a great 
favorito in Louistile, Heted the thy many timos in after yoars.

The next star was Filliam.C. Forbes, a young man of about trenty-four years of age who was attempting to eatablish himself as a leading tragedian. He played in HAMLET, YILLIAM TELL, VIRG HIUS, RICHARD III, DANON AND PYTHAS, KATHERINE AND PERTRUCHO, and JULIUS CAESAR. He bad a certain amount of mirit, but he was not a genius, and receipts during his engagement at the theatre were not very large. He was intator of the American tragedian, Cooper. The reather in June and July is often very wam; so after the produttion of several spectaeles, and the usual round of benefits for the company the theatre was closed on the fourth of July, 1832. -

In 1833 and 1834 the cholera raged in New Orleans and in the far south, and Mr. Lud low and his family removed to Loulaville to be safo.

During the summer of 1834 two very excellent artists, Mr. and Mrs. Thomas Hilson, began an engagement to plerg with Mr. Drake at the theatre. They had played only a fer nights when Mr. Hilson died of epoplexy. His on was highly esteomed as an actor and a centleman. cooper considered his Iago in OTHELLO as the best he had ever soon in England and America, and James H. Hacked considered Hilson's performance of shylook an admirable piece of work. The

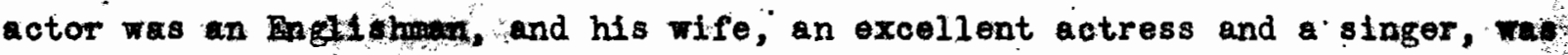
an Ameriean.

About the middle of June Thomas D. Rice performed Jim Crow and other negro selections at the theatre, and following him came Mr. Junius Brutus. Booth, the elder Booth. How many times prevlous to 1834 Booth had performed at the City l'heatre, we have been unable to learn. He may have played there several times, or it may hare been his first appearance, for Booth did not o to this country until 1821. Booth wes avery wonderful actor, and no lesa a person than Joseph Jefferson sald of him, "The greatest actor I have ever seen was Junius Booth. He was not the oqual of Macready as an intelleotual artist, but his spirit was oxtraordinary and overwholming. When he acted Sir mies you never thought of looktng at his feitures and motions; it was what w insid 
of the wan that you but Ho free, in the liat aot, used to twithi ho was like a wild beast." Finter, to whom the above remark was made, goes on to say of Booth, "Yet his acting was art - not delirium - unless intioxicated his brain retained absolute control of his enotions. Booth played many parts, there is descriptive rocord of him in about twenty of the greatest; but probably he was at his best in King Richard III, Sir Giles Overreach, Sir Edward Mortimer, Iago, and Shylock. Booth's poovltar geandeur was in the region of the supernatural and the terrible." (Finter - The Hellet of Time - V. 1 - page 92.)

Booth was a good man, and he loved his children dearly, but he did become highly intoxicated at times. This oraving for drink on thepart of his father was one of the great troubles of Edrin Booth's young I1fe, and he didallin blo power to help his father conquer the bubit. But with all bil: goodness and kindness of heart, JuniussBrutus Booth was given tp strange moods and when one of these moods seized him he would do some of the queotest deeds that men could imagine. Vililiam Hinter attributes a great deal of this moodiness to grief over the death of two of his children. He had been subject to the spells before, but after that sorrew, they grew worse.

Ludlow relate two or three incidents about the visit of Booth in 1834 which cannot help being of interest to Louloville people. He gives the follogrty incidents, and wo have copled them in his own words so that there may be no mistake in the relating of them.

"Following him (Rice) came Mr. JminesB. Booth, Sr., who commenced an engagement; but after the firat night, was seized with one of his sentlunatic attacks, and enacted some of the most extraordinary freaks that erver entered the mind of man, supposed to be sane. Passing the theatre doer on a Saturday afternoon about firo o'elook, I found Mr. Booth on the sidewalk, with a board upon tro expty barrels, on which were lying number of rats which had been eviscerated; and as the people passed by with their baskets to the neighboring market, he would stop them and endeavor to persudele them that those rats were infinitely botter eating then any kind of animal food 
that they could purchese ath ofurket; that thoy were moro tender than squirrels, and eleaner than hogs. However, I belleve he obtained no converts to his system of dietetics. On the night of this same day Mr. Booth performed the character of shylock in his ubual excellont manner.

"Mr. Rico remined in louleville after finishing his engagement, and was there during the time $\mathrm{Mr}$. Booth was perfoming; and from him, an eye-witness, I learned the following partleulars of one of. Mr. Booth's most extraordinary and fantustic adwentures: $\mathrm{Mr}$. Rice was sitting with Mr. Booth one afternoon, in social conrerse, in a room at the hotel where Mr. Booth was stopping, when clergywain, the Rev. Mr..-, was announced as calling by the request of Mr. Booth. Hewmas desired to walk up to the room, and on entering inquired for Mr. Booth, who stepped forward and was thus addressed by the reverend gentleman: Mr. Booth, I have ceme to perform the last rites of our church over the decessed, as you desired I would." Mr. Booth bowed, thanked him, and desired he would step with him into the adjoining room. As they did so, Mr. Rice, not a littie amezed, followed them; and arriving at the back of the room, Mr. Booth, lifting black cloek, pointed to small coffin on table, and romoved the lid of tt. The clergyman, in a very olem manner, advaneed to it, and bending his head over the coffin, gazed at the object within, and stepped back jalbikly with a look of astonishment and horror. Suddenly turning his eyes on Mr. Booth, he said, 'Pray, sir, what is the meaning of thls?' Of vhat, sirq' said ur. Booth. 'Of thts,' pointing to the coffin. 'You requested to come hore and perform the funeral rites of the dead, and you present to my astonfshed senses a poor pigeona' 'Kell, sir,' said Booth, 'is it not dead?' 'zes, but this is an animal.'Me11, 815, is not man an animal?' 'Truly sald; but it is not a human, - it has no soul.' 'How do you know, sir, that it has not a soul?' By this time the reverend gentleman had gradually backed out into the other rocm, and gettingnear the door, with fughtened look, said to Mr. Booth, 'I will not suppose, sir, that 


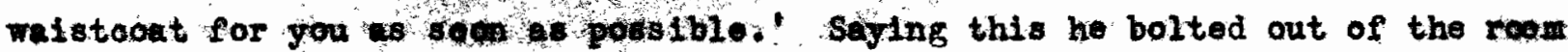
and hastened away.

"I have good reasons for believilg this to be exactly true, for some ten years ago (ladlow wtote in 1880) I read in a Festern newspaper an account of this incident, said by the writer to have been given to him by the clergyman referred to.

"there used to be atory told, and not many years ago I read it in print, that among Mr. Booth's eccentricitios was that he carried with him on his professional journetre the skull of fxiendoof his, which he used for Yorick's skull in HAMLET whenever he enacted the Danish Prince. I will not undertake to say how much truth there may be in this story, but I will state a circumstance that in connootion with $\mathrm{Mr}$. Booth's whll-knom strange humors, leads directly to the door of probability.

"During this sojourn of Mr. Booth in Louisville (1834) he became acquainted with a man known as George Lovett, but whose real name was Fontaine. This man, it was said, came of very respectable family, and was well educabed. For many years he had led a rery dissolute life, and when about thirty years of age was arrested, ttied, and condened to be hanged for highray robbery and murder. Ho ras in jail in Loilswile, awaiting exeoution, at the time of this visit of $\mathrm{Mr}$. Booth to that city, One night, Mr. Booth, returning to his hotel at late hours, fter a wild revel, was resy nolsy in the street, and being requested by a wateman to desist, bejocame abusive; and on the guardian's of the might ttempting to arreat him, he resisted, but was overpowered and taken to ja1l, a portion of which was then used as a guard-house, where he was locked up in a coll until morning. When left to himself, he commenced singing the popular Bnglish song of the 'Pachers'. I'hts attracted tho inmete of an opposite cell; the before-named George Lovett, who came to the grating of his door, and addressing Mr. Booth soon found out tho he was; satd he had often seen him aot, was a great admirer of his acting, and orinced so much judicious oriticism that $\mathrm{Mr}$. Both was attracted by his converated on, and 
thoy talked together unt 1 oglggh, when both lald down to sleep. About neon of the following day I rocelved a not from Mr. Booth requesting mo to cell on him at the jail, which I did, and found him in the some cell with Lovett. The jeiler having found out who he mas, had, at the request of Booth looked hin in the cell with Lovett, ferter searching the former to discover if he $\mathrm{A}^{\mathrm{any}}$ thing concealed that wis not allowable. On my presenting myself, being vellknown, I was permitted to enter the same oell, where I remeined neally an hour before I could induce Mr. Booth to go away with me. In conversing with Lowtt, I found him a man of fine loterary take, of considerable reading, and of general intelligence. It was a iatter of wonderment to me how a man of his aoquirements could permit himself bo become so debaed. I took Hath to $_{\text {. }}$ my house, and after a fer hours sleep he arose, washed and dressed himself, and asked to walk with him; when he tack to three or four drinkingsaloons, at each of them redeeming some trifle - a ring; a knife, a gold pencil, or some other sall pledge - left the night before for drinks. It wae a custom with him nover to have any money about him unless when traveling, and then only enough to defray contingent expenses.

"Mr. Booth left Loul erille for the East before Lovett's sentence wes cully carried auty but Mr. Blce, having to remain on some business, was there when Lorett was hanged. By Mr. Rice I wa told that, in accordance with an agreement between tho tro mequloyett head was to become the property of Mr. Booth after the requirements of the 1 aw had boen fulftiled. And from another person I heard that after the exectition the head was serered from the body, was prepared for transmisalon east, was given in Mr. Rice's charge, and by him delivered to Mr. Booth at Philadelphia; and he I heard, after putting it into proper condition used it on the stage for the skull of Yorick! 'Alas! poor Yoriok! ' " (Ludlom-Dramatio Life As I Found It - 41617/ The Courier-Journal for November 24, 2889 relates an amusing incident thich occurred when Booth played HAMLET during the engagement of 1834. The orchestra at the theatre was made up of players who played almost entirely 
by oar. Tho stege mangar had fafornad theil that thoy were to play sonothing soft when Booth died as Hamlet. In thoir interest in the play and the acting they forgot all about the misio until they sam Booth fall over dead; then in their excitement the leader stmick up "Old Jerry Phipps" or "Oh Law, Girls, Don't You Viant To Go To Shtppingport". The audience smiled, and the boys in the gallery began to yell, "Sing corners! Fands all 'round!" When Booth heard the music he rolled over on his stomach, ralsed himself on his hands and knees and gave the orchestre withering look. "Thenhbe got up, bowed to the spectetors, looked again at the orchestra, and left the stage. It is said that Booth never heard the name of Loulsville mentioned that he did not remaricthat that wast the city where the orchestra played dance nusic when he keeled over dead in Hamlet.

Mr: Drake was very suocessful in the management of his theatres in Kentucky for the first ten or twelve yeare, and during that time he bought in Frankfort the building of which the theatro a part and a farm in oldham county, about twelve miles fron Louisville. He mat also have purchased the Louisville theatre building, for it belonged to him at the time it bumed. Several years before 1ts dlsappearance, Brake had retired from the managent of the clty Theatro, cha It reputation had deteriorated. The glory of the old playhouse had departed, and wany of the altizens were glad whon it was gone, although it represented loss of a great deal of money to Mr. Drake. who had invested much of hts earnings in it and carried no insurance on the

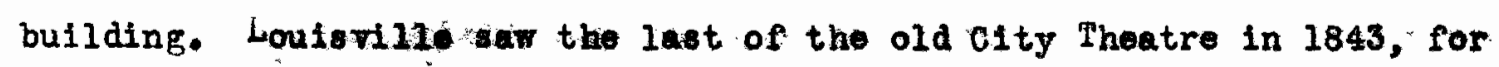
shortly after midnight on May 21 of that pear, the bullding ras destroyed. One historian (History of the Fells Cities and Phoir Counties V. 1. - Page 220) says that oren before the old theatre was destroyed ar. coleman began the building of new theatre at the corner of Fourth and Green (Liberty) Streets, but ebtecomo reason he gave up the attempt after he had erected the outer. wal18. J. Stoddard Johnition (Memotal History of Louisvil10 - V. 2 - Page 329) attributes this attempt to ereot a nor theatro 


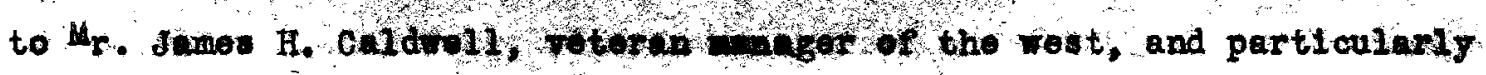
known for his New Orleane theatres, In the fall of 1843, Ladlow and Smith; at that time manaing theatres in Mobile, St, Loals, and New Orleans, made an offer to the stockholders who rere finanoing the projected new theatre In Louisville, the building of which, ludzos says, stopped because of lack of ands. The offer was relative to a lease on the theatre if it should be finished by a certain date. Mr. A. J. Ballard refused the offer on behalf of the stookholdere because they were unfiling to invest any more money in the project.

Thaterer many have bein the roal reason, the fact remains that boulsville remained without a theatre until 1846.

Daring the time of the City Theatre, there existed in Louistille several emdens, where there were amusements of almost anykind to be en-. joyed. There was horse-racing, foot-racing, mreatling, shooting at the merk, gander pulling, and sometimes even arrough and tumble fight. The most prominent of these gardens was Veux Hall Garden, kept by Clarke and Myers, where one could hear music or speaking as one desired. The garden was located on Fifth street. between lain and the river. In the east and of the of ty was Foodiand Gardea kept by H1lliam Prtete, und in the western part was Elmtreo Garden. It was at these latter numed pleces that one could find the more energetio amusements mentioned above.

Before ve sperk of the next theatre in Louisville, we foel that it is flting, to tell briefly somothing of the lives of the Drake family and of one or two of the company who came into the far, far Fest" to bring the dram to Louisville and to Kentucky. (These biographies are condensed from Ludlow - Dramatic Life As I Found It - Page $363 \mathrm{ff.})$

Samuel Drake, Sr., "old Drake" as he was often called in Loulsville: was boon in England, on November 15, 1768. It ha been said that his roul name was Samuel Drake Bryant, and it was also said that he had beon bound out to learn the printing trade, but that he ren away before his time was out, 


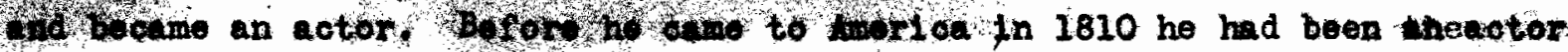
and a manager in severel country theatres in Ingland. There he married a $4 \mathrm{ss}$ Fisher who came with him to Imerica. At first thot were in Boston, but in 1813, they joined the company of Bernard in Albany, and Mrs. Drake died in that city in 1814. The next your Drake to Kentucky with his compiny. After his retirement as anagor, he lived on his farm in 0ldham county, where he died, October 16, 1854. Louisv111e owes more to Samuel Drake than she perhape realizes, and his theatre and his work here should not be forgotten.

Samuel Drake, Jr., was Mr. Drake's eldest son, Hewewas bonn in England in 1796 and comestoothe Jinited States with his father. His father intended that he should be violintst, and he was the second violinist at the Albany theatro in 1814. The leader of the orchestra at that thaatre was Nonsteur Mallet, the original of Batle Bernard's little dra called MONSIEUR MALIET which James H. Hackett played for many years. On his way to Kentucky, he played in many plays and likemise offleteted as the orhestra leader, and sometimes as the whole orchestra. "Sam" Drake was very well liked, but he was not considered as good an actor as hls brother Alexandar. Semuel Drake died in cincimati the ge of thirty years.

"Aleck" Drake was two years younger than his brother Samuel, and he was better biom as an actor. Hl special business was lon comedy, and in his characterizations of country boys he had fex rivals in the United States. He was a great favorite in Kentucky, in Cincinnat1, and in Pittsburgh. Ludlow mentions that Aleck Drake wes deaf, but the affliction must not hare been serbous enough to interfere greatly with his work on the stage. In 1823 he married Frances Ann Denry, the young lady who was the novice with Drake's company when they started for Kentuoky. Mlexander Drake dida in 1830. His daughter, Julia, was the Mrs. Farry Chapman who often in later years played in Louis 1118. 


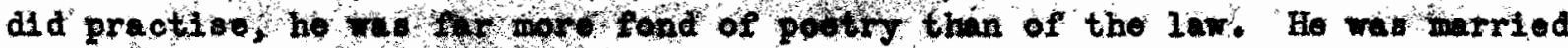

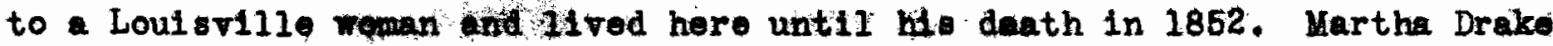
was the eldest of Mr. Drake's children, and although she played in his company, she was not a very good actress. Shortly after the arrival of the company in Kentucky she arried Mr. Duckham, an Englishan. She died in England manyears later.

Frances Ann Donny, or Mrs. A. Drake, of was known for many jears to Louisville theatre-goers, was born in Schenectady, New York, Norember 6, 1797. The first part she over played ras that of Julia in a comody called the MIDNIGHT HOUR at the 1ittie town of Chorry Valloy in New York in the course of the journey to the west. The first tragio character she played was Ima in M. G. Lowis's play NDIGITHA, Mrs. Drake was one of the best and most popular cictreses of her day, not only in the west and in the south,. but in New York and the East. After the death of her husband, Alexander Drake, in 1830, she married a Mr. G.T. Cutter, but her life with him was not happy, and upon mutual agreement they separated, and she resumed the name of Drake. At one time she had a beautiful home at Covington, Kentucky, but the last yoars of her l1fe were spent. on the farm of her son; Semuel Drake. The farm was the one in Oldhan county which had been left to bis grandson by the elder Drake. Mrs. A. Drake died on September 1, 1875.

Nowniller Ludlow, who irote the book from which so much of our Information about the early theatro hed been taken ins born in How York City in 1795. In 1817 he married Mrs. Squires, a widow who had been Miss Mary Maury. Ho met her in Louisville during the second season which he played with Drake's company. For many years he was one of the leading managers of the west and south.

The bright particular star of the Drake fanily was Julia Drake. Sho was the younger of Mr. Drake's daughters and was born in England in 1800, Sho was a very beautiful woman, and possessed a grreat deal of acting ability. Her Lady Teazle in the SCHOOL FOR SCANDAL was a fine piece of acting. "She was 


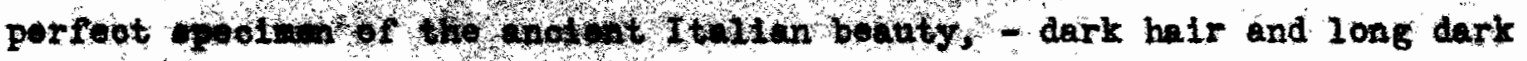
eyelashes; hor eyes had peoullerly happy, Itrely expression."

Julia Drake had not had very long career as an actress when she married eincinnati merohant named Fosdiok. The Fosdicks had one son, W. T. Fosdick, who became well-known as a patt. After Mr. Fosdick's death, Julia Drake married an aetor, Edwin Dean. Julla Dean was their daughter. "In 1832 Mrs. Dean died in Now York, leaving hor daughter to beoome the famous actress which the mother might have been had fate so willed it. The roice of Julia Dean was very like her mother's, mistoel, full, and joyous, but tho mother was even more beautiful than the deughter, it is sald, although piotures of Julia Dean almost mike us think that bist is scarcely possible.

With the destruction of the old city Theatre the early history of the theatro In Louleville bocame a thing of the past, and the city only aratted the erection of a new theatre to continue its progress as a centre for the theatre and for tters dratic.

During the time that Loxis ville was without a legitimate playhouse the citizens did not suffer from lack of amsoment. A hall called the Apollo Rooms, loonted on Third Street above Mr. Peters' musio store, was a favorite plece for holding oogerts of which there geemed to be no end. Tashington Hall on Fifth street housed many famous panoramas; and there we persmitted to viow such curfosities as the Kentuoky gientess, Miss Browning, who was seven leet tall.

The Congo Serenaders on December 6 and 7,1844 gave two of their "chaste, agrequble, and unsurpassed conoerte" at hashington Hall. These serenaders as well as a band called the Origlial Ethiopien Serenaders seem to have been very popular and never falled to draw large audiences.

Some of the favorite performers of the dey were a Mrs. Vebster who sang frequently, Mr. Edward Lehmann, a futiat from Coponhagen, Mr. Duffield, a singer, Mr. J. B. Smith, blind pianist, and Mr. Cunter, concerts were given by the saint Cecilia Society, local organization of singers who were 


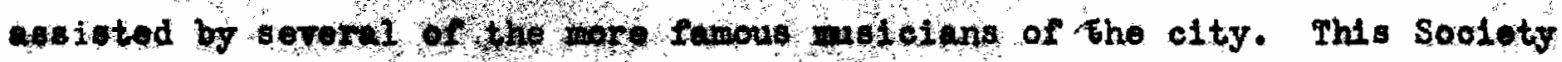
was very popular, and 1ts coneert were well patronized.

The most famous masicten who appeared during 1844 and 1845 was 010 Bull, the violinist. He gave one concert on the thirtieth of January, 1845, and three others on way 6, 7, 8 of the same yoar. After the first concert: the coriticism of the newepapers was not partioularly favorable, but after the latter three he was. spoken of as "a man of intelligence and genius-a man of the world - ald also gentleman in his manners and deportment." It was several years later, in 1852 and 1863, when he played and Adelina Patti sang tht the real worth of the wonderful artist mas truly felt.

Pea-parties of every kind, and for every purpose, were the order of the day, and there seems to have been bordes of clrcuses. They usually appeared efther early in the spring or late in the fall, but one or two were neaziy always to be found either just arriving or departing. The favorite circus grounds seem to haresat Third and Green Stroets. Lator tho places shifted. Falnut and East Streets, First and Vialnut, sixth and Jefferson, and East and Chestrut were usual comping grounds for the eircus tanta. Stiokney's Circus, Howe and Mabie's New Yook Circus, G. R. Spalding's Americen Circueg ond The Groat Nortbustern ctrcus wore powerful drawing cards. Barnum's Museum and Managerio was in Loulswille on Hay 16 and 17,1853 , bringing with it such famous attractions as Tom Thumb, Mr. Nell1s, the armless wonder, Mr. Plerce, the lion tamer, Barnums wax works, and the far-famed baby elephant. Ton Thumb had appeared several times before ho became member of Mr. Barnum's menseum. The first time be appeared was when he was fifteen years old. At that time ho was twenty-eight inches tall and reighed fifteen pounds. The tiny general with his miniature carriage was a great curiosity and likewise a great favorite with the public.

The era of magicians was just beginning early in the forties, and for many years after we find an over increasing numer of these men who mystified and charmed the people of that ofy. One of the earliest ones of whem we find 


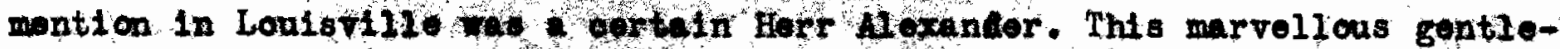
man delighted his audiences by shooting gold watches through chair sents, by putting froshly laundered handkerchiefs into pail of water and bringing them forth dry and ironed, and by producing whole cartload of dry goods frcon a gentzeman's hat. This magician performed here in 1844, and maxy time afterward he appeared at the Apollo Rooms.

In the editorial columb the Loulsville Morning Courier for June 13, 1844, we "flnd these words under the heading "A Theatre in Lovispille." "We have intended for some time to say. word on this sulject, and in condemation of the apathy wheh existo with our infiuential citizens and property holders in regard to 1t. The went of neat, capacious, and respettably conducted Theatro in this elty is severely folt and generally ackowledged. The idea thrown forth by the bigoted onemles of theatricals, that the face of the community is set rigidly against them, is scarcely worbhy of consideration or serious notice. Such concerns as we have had in Louisville for the last six or eight years, and until they were both destroyed by fire, were not recg8nized by poople of taste and principle, and should not be a criterion of what might be expected from an enlightened managenent, and wo believe we speak the truth when we sy that our oftizens only require guarantee of respectability and morality, to bestọ upon the stage a steady and compensating - Dupport."

The article ends by explaingarg that the lack of a theatre was very injurious to business, for travelirs would not stop in city where there were no roal amsements, and business men would not found enterprises thero, either. The editor suggested that the property on Fourth and Green (Liberty) Streets wes the most eligible and centrally located. It could also be bought on very reasonable terms, and the theatro could bo completed with a bmall expenditure of money.

Practically no theatrical performances were given during 1844 and the first part of 184. In May of the latter year, scott and Foster orected a 
kind of temporary thotho on Groon street botreen Fifth and centre streets and callod it the Pavilion. It is sald that the pavilion wis fitted up in really comfortable style, that there was an abuance of room, and that it was well ventilated. The stage was larger than that of any theatre which had been in Louisville up to that time. The scenery was all newly painted and in "good style."

The Pavilion was poned on May 27, 1845, with a performance of LA FEME MUET folwowed as over by farce celled CATCHING AH HEIRESS. The company seems to havo been an exceptionelly good ong, for it included Mrs. Kont who afterward was for several years a fopular member of the Bates stock company at the Louisville Theatre, Mre. Bore, Mr. J. M, Soott, Mr. Meafie, and Mr. Logan, the comedian, "the great inimiteble, mirth-provoking, side-splitting Logan. The Pavilion was very popular during its brief $11 \mathrm{fe}$, and such plays as THE HONEYMOON, THE MERRY MONARCH, THE YOUHG HIDOT, THE LOAN OF A LOVER, MR? AAND MRS. PRINGLE, THE MIDDY ASHORE, THR STRANGER, ROB ROY' PAUL JONES, THE WIDOS's VICTMM, DAMON AND PYTHIAS, LUC ILLE or S Story of the Heart all found ready and eager audiences. One dram called ELLEI TARRHAU mast have been a gem. The adrertjobmonte anounoed it as a tragio dram with the following incidents: the marriage; the letter; the d porery; the husband' retern; the poison; the death of cressford. What pablic could resist such convincing and attreotive adrentising? The season at the Parilion lastdidout six woeks, closing wth the usual benefits for the managers and the popular players.

On October 21, 1845, the Morning Courter announoed that Mr. John Bates had leased the ground at the corner of Fourth and Green Streets and the briok walls standing on it and that it was his intention to complete the theatro as early as possible, probably by tho middle of December. A Courier-Journal of October 13, 1873, states that the ground was leased by Bates from colonel Henry Clay, Jr. The news was very gratifying to the poople of Louifoille, for they hed been without a theatre for about three years, and they knew 
Louisvilie.

The scenio vorl for the thotre was cone in cinelnnati by an artiat named Lesl1s, and one of the Cinolmati papero remarked abont the dropcurtain designed for the hew Louloville theatre that we will just drop the remark, that a more legant "drop" nover yet dropped before an American audience."

The Morning Courier for Fobruary 3, 1846 said this about the new theatre whioh was almost ready to be openedy "Te have seen enough to pronounce it (the theatre) the most complete; the handsomest, the best arranged, the most beautifully decorated, and the neatest theatre in the Fiest or south, or oven in the United states. The stage is lerge and commodicue, and the building will very comfortably accomodate trelvo mandred persons. The dropcurtain represents a view of the Gapitod at Wushington and is one of the best offorts of thattwell-knom artist, Leslie. The panels of the first tier of boxes are ornemented with some ten or twelve exquisite paintings, exceoted in the very highest style of art the very first artists of cincinnati. There are several boxes for the use of families and private parties, most admirably arranged, and in whtch a person:can bo as retired as in their

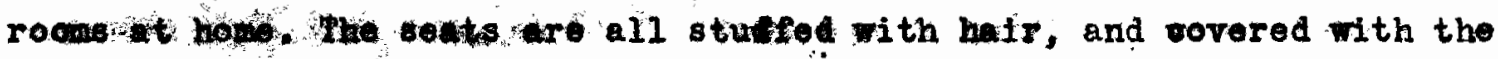
finest Brussels carpeting. They are better arranged for comfort than in any Theatre we have over been in. Tho whele bullding is brilliantly lighted with gas. The pit is also admirably axranged for comfort, and we think it more than 1ikely that its pleasant arrangement will frequently invite sono of tho upper ten thousand who are disposed to be saring of their "dimes." The whole establishment will be under the immediate superintendence of James F. Bates, Egq., the well-known and efflcient moneger of the National Theatre, Cinoinnati. He opens with a strong and efficient stock company. The great desideratum hes at last been supplied, and to the enterprize and untiring energy of Mr. Bates is the Loulsville publie indebted for the speddy erection of a dramatic temple, which is an honor to our eity." 


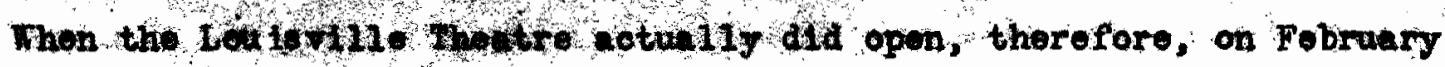

9, 1846, the publ10 was probably kayed to high expectancy, so that a

"Iarger, more reapeotable, more brillians audience of ladies and gentlemen we have never seen collected to witness a public patertainment in Loulsville." The advertisements in the papers ran thas:

THE LOUISVIELB PEEATRE.

Jas. T. Bates

D. A. sarzedas

Admi ost on,

Proprietor and Manager. Acting and stage Manager.

Private Boxes .....................\$1.00

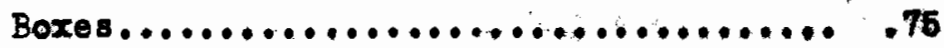

Children under $12 \ldots \ldots \ldots \ldots \ldots . \ldots \ldots \ldots \ldots . . .60$

P1................................ 60

Gallery.......................... .25

Gellery for Colored Persone.............25 Doors open at 62 . Curtain at 7 precise.

Box office opon from ten to ons, and from three until five.

( $A$ strong and effletent Poljce is engaged to proserve Order.)

The first stook company consisted of the following actors and actresses:

Mr. Adams, Mr. Green, Mr. Dean, Mr, Dougherty, Mr. Barry, Mr. Roys, Mr. Rodgers, Mr. MCRicker, Mr. Mack, Mrs. Hent, Mrs. Tiarren, Mrs. Salzman, Mrs. Adams, and Miss Dean.

The pieces of the openigg night were PDagtas Jerrould's TME rORKS WONDERS wth Miss Dean Florentine, and an afterpiece, THE VIDOF'S VICTIM of the stage stuaik chamberma1d.

The theatre was filled in every part, and the actors performed their parts with spirit. Mss Julla Dean spoke the opening address, and Mr. Messemer performed "Luoy Neal" on the cornet - - piston. The citizens of Louisville gave a demonstration on that night of their intention to patronize the theatre liberally. Mr. Bates, on his part, assured his public that he would leave nothing undone that would tend to its pleasure and amusement. Un the whole, it must have been a very momontous occasion, and when we realize that during the years of its existence the old Louisville Theatre housed the most famous actors and aotress of that day, we understand tore thim that first night audionoe just what the apening of the Theatre moant to the city of Louiavilie: 


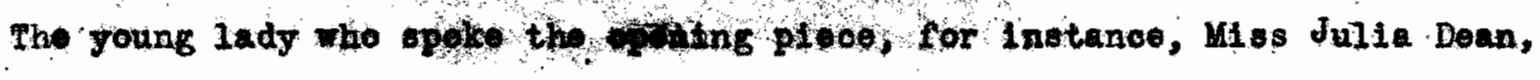
was later one of the farorite and best actresses in the American stage. sho was a deughter of Julia Drake and Edwin Dean, and a granddaughter of somuel Drake, Br.. Miss Dean was born In Dutchess County, New York, July 22,1830 , at the home of her paternel crandparents. The early years of her life were passed in seclusion with her father's parents who were quakers. After her mother's death in 1832, her father married again, and Julia, when about fourteon, with her father and step-mother became members of the company of Ludlow and smith who stationed them at the theatre in Mobile for the season of $1844-45$. At the tme of her flrst appearance in Louisville, therfore, Miss Dean yas not yet alxteen, and was practicaliy unknown. Joseph

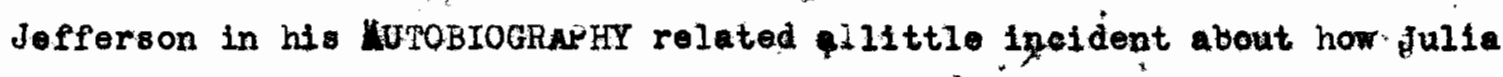
Dean played her first leading part. The occurrence took place at the Mobtle Theatre whore Miss Defienad Jefferson were playing omall parts for six dollers a reok. Une night the leading lady maerill, and the modest, shy Julia offered to take her place as Lady Prlory in WIVES AS THEY IERE AND MAIDS AS THEY ARE. From that time Julia Dean played leading parts herself, and seven years later when she and Jefferson met in Charleston, she was tho leading fuvenile actross of America, and ho was the manager of the theatre in charleston.

The first season the Louisvillo Theatro lasted from February 9 until April 18, 1846, closing with a benefit for Mr. Bates, the manager. During the season many pleye were presented, some of which are just as popular as they were then, and othere have disappeared along with the nights and the theatre which saw them produced.

One of the favorite plays of the season was THE LADY OF LYOMS. It was for years great attraction, and almost every otar included either Claude Melnotte or Pauline in his or her popertolre. Miss Dean played Pauline here several times, during that first season, and she was very pleasing in the part. She also played Julla in Sheridan Knowles play THE HWCHBACK, 
and hor aoting was highy profed wo was also that of Mrs. Hont who was a very fine actress, too. The whol compkny was a rery good one with one or two exceptions, and these one or two "were never fitted for the stage by nature or genius, and the socner they leave 1t, the better it will be for thenselves, as woll as the publ10." (Morning courier.) The public was a critical one, and sereral of the gentlemen players were severely reminded through the press that they should pay more attention to their costumes, and that a shine on their boots would help their appearances. Mr. E. S. Conner, billed as the famous American tragedian, joined the company curing February, and taken all in all, that first season sering to hive been a serles of very good productions. Doubtless sometimes the actors forgat sema of their lines, and the whole oompany was not all thit could be desired, but a list of the plays presented will give some idea of the attractions offered to the public. Among othors we find SHE STOOPS TO CONQUER, THE ETGLISEMAN IN INDIA, in which Mrs. Kent scorod a htt as sally soraggs, MARRIED LIFE; RICHELIEU; CHENEY PIECE, Lord Byron's VERNER, THE STRANGER, THE HEIR AT LAF, LA TOUR DE NESLE, THE IRON CHEST, RICHARD III, THE SCHOOL FOR SCANDAL, DAMON AND PYTHIAS, ALEXANDER THE GREAT, VENICE PRESERVED, FAZIO, 4 NET, FAY TO PAY OLD DEBTS, and A TRIP FROM LOHDOY TO PARIS.

Thts seens a very formidable list of plays to have been produced in the * short space of two months, hut it wes not at all unusual. It is no wonder that the actors did not always knor their lines when they were required to somember the lines for so very many characters and to learn new ones at very short notice.

Miss Dean and Mrs. Kent seem to heve been the favorites that season if accounts of their benefits mean anything. For her benefit Miss Dean played Elvira in PIZARRO and Joan of Aro in the play of that name. She had bocomo recognized as a young lady possessing fine talentis, and "her correct and modest deportment won the regard and esteem of houts of friends." Mrs. Kent took her benefit on Apri1. 11, presenting SCBNBS IN IFDTA and KA'PHERINE AND PETHUCEIO. 
On that night the houbs was cronded; abd bouguets and beskets containing money hidden in the floners were throm on the stage to the lady. entors.

Miso Josephlnepappered star; but hor acting in the HUNCHBACK was considered somewhat inferior to Miss Desn's acting of Julla except that Miss Clifton's conception of the part was more finished and perfect, more complete in deteil.

James H. Hackett, the famous Falstaff, arrived on March 13, 1846, fully expecting to appear at the theatre, butio difelculty arose between him and $M r$. Bates in regard to the remineration ho was to receive, and Hackett departed without having appeared. Louistille theatre-goers wore greatly disappointed, and some of them poro disposed to blame Mir. Batergsinertingthat he had acted in too arbitrary manner. It mas some years before Hackett appeared in Louisville again.

Just before the theatre closed, Jin Crow Rice, the famous tipersonator of negroes, appeared in several of his famous oharacters, notably Jumbo Jim and Jim Crow.

On May 14 a place called shire's Garden was opened with a production of DON CESAR DE BAZAI, and several pleys wer given there in the course of the aumer, but it gradually drifted into the varieties; and did not produce logitimate dram after the first fow woeks.

On May 25, 1846, the summer season at the Theatre began. Mrs. Nent was again in the company whi ch Included besides herself, Mr. T. Placide, Mis8 El1za Logan and hor father, Mr, Cs A. Logan, and Mr. E. S. Conner. Several good plays were enacted, ammet them MOREI by Bulver, CURE FOR HEARTACHE, LOVE'S SACRIFICB, THE LADY OF LYONS, HENRY IV, VIRG IUIUS, OTHELLO, , and VENICE PRESERVED. With Old Logan and his daughter, Ton Placide, and Mr. Conner it seemed that there should have been drawing power enough at the theatre without a star, but the houses were not good. The small audiences may have been due to the fact that the wother was warm and perhaps to the fac $t$ that Stickney's and other cirowed for holding porformańoes, and there 
were numerous conerto bontrathys

Early in June Booth played an engagement at the theatre and matters became somewhat better. At that time in 1846, Booth played RICHARD III, Iago in OTHELLO, Sir Edward Mortimer in the IRON CHEST, KING LEAR, A NET YAY TO PAY OLD DEBTS, and Cotint Peseara in the APOSTATE. Ho took two benefits one in KIHg LBAR and one In I IET FAY TO PAY OLD DEBTS. At that time it was said that Booth seemed to have lost mioh of his former fire, and yet ho played Richard as only Booth could pley 1t. The season lasted until July 14, and in that time Murdooh appeared as reinotte in THE LADY OF LYONS, as Hamlet, as Benedick in $M U C H$ ADO ABOUT FOHING, and in the GAMESTER. Silsber, the Yahker comedian, played an engagement aloe. Ho closed the season playing Jonathan in FOREST WOSE and B 111 in the YANKEE PEDLAR. On the olosing bill also was the MAID OF MUNSTER with Mr: Cenner, Mr. T. Placide, Mrss Thorno, and Mrs. Warren in the cast.

In the interval between the summer season and the opening of the fall one there were clrasses and numerous concerts at the Apollo Rooms. Among the most notable of the concerts was that given by the Hisses sloman who were harpisto, pianiats, and rocalists. There were tea-parties and a wide rariety of entertainments to keep the amusement-seekers busy.

On September 3, 1846, the third season in the history of the Louisille Theatre opened with a performance of THE HONEYMOONTand the KIDOF'S MAID OR THE WADE FIDOF. Several of the former cempany returned for the fall season including Mrs. Kent, Mrs. Karren, Mr. Comner, and Mr. Barry. But on the wholet the stock company was a rediocrolo, and the public was not slow to show its disapproval by not attenasing the theatre. The play, THE KIDOF'S MAID, was written by a Cineinnatian, and the press of Loulsville and tho public as well regarded It as a "rather poor, shabby affalr - a humbug, a real cincinnat1 humbug." The actors, however, played their parts in it to satisfaction. The attendance at the theatre somotines did not amount to more than twenty or thirty persons until wotuber 14 whon Dan Marble, the fumous 


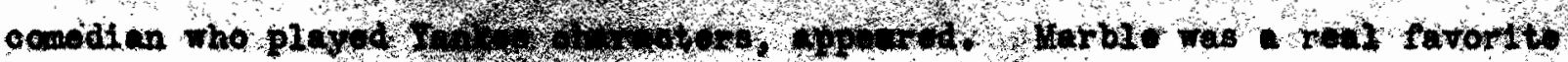

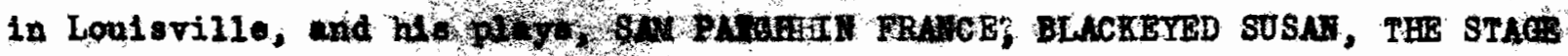
STROCK IANKEE, and TOL OREG'S log wore wery well received. He also playodd during this ongegenent a play alled FaILY TIBS which proved so popalar that It wes repeated for three ntghts in swcoesalon. The play had boen severiy

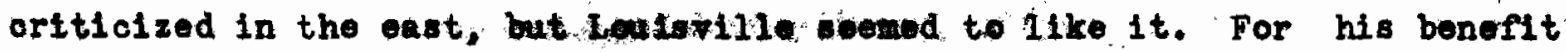
on September 19, 1846, Mrbio played in THE IMES THAT TRIED US.

On September 28 the epectecle of $\triangle$ LADIY or THE TONDERFUL LAMP res produced with "entiraly new und gorgonis cenery, dresses, mechinery, properties, deopbation, and stage appointmente, wt tho oost of over ONE THOUSAND DOLLARS." Mrs, Kont playod Alladin, and tho play continued for several night until Murdech, the tragedian appeared. Misa ELIza Logan camo to the theatro at the sane time, and the oompany was consfderably strengthened by her coting. Murdoch performed his uweal repertaire of BMLET, THE LAII OF LYOIS, THE GAMESTER, THE SECRET OR THE HOLE II THE FALL, MACBETH, and the FONEMOON, He took his benefit on Ootober 10, 1846,10 THE IMCONSTANT and THE STRANGBR.

Conndr took benefit on Ootober 17 , and In speoch before the curtaln he made it known that the poople of Loaioville did not know how to apgrediate

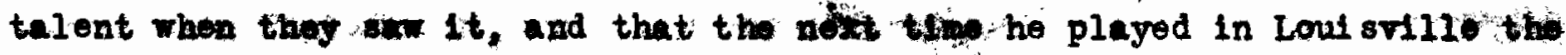
manager would have to pay" hill better orithe rould be th tiant of bread. Evi-? dently the benefit did not cono up to lis. conner's expectations, and both

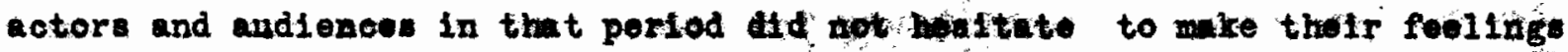

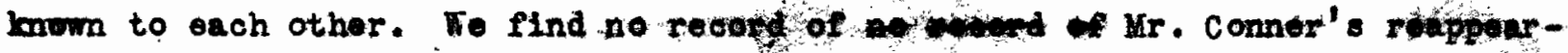
ance at the Louisvillo Thentre, at lend whtin the linte of this porlod.

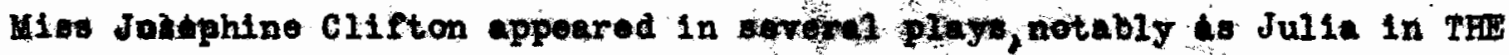
HUNCHBACK. But the seares proved 60 unplesfteble that the theatre was closed on October 24 just when it should have bodn in full bwing.

It re-opened, howorer, on Monday, November 30, 1846, with THE BJICHBAC

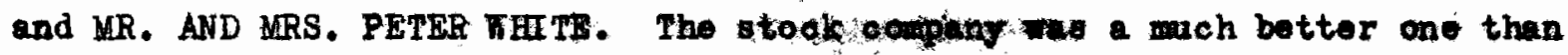

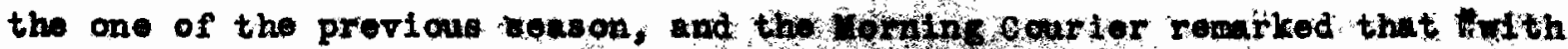




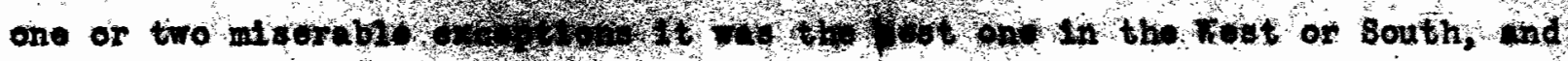

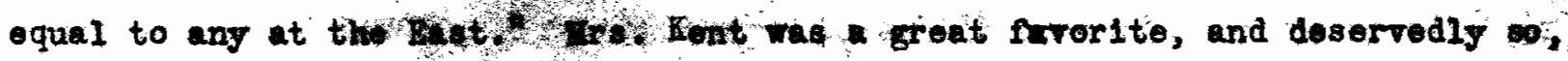
for she was inimitabie. Alisw login, who was otill very young at that time, was improving right atong. Ne. and Kro. O. F. Smith were very fine in the Eine of parts they pleyed. aud Mr. Horris wa very excellent actor, and Mr.

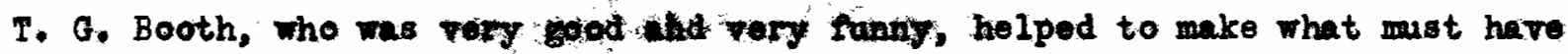
been really exceptional oquang. The season was not successful, horever; In opite of the frot that Mas logan and $\mathrm{M}$. Morris played in ROMBO AND JULIET, and performanoes of SHE, SHOOPS TO COHQEBR, THE MAID OF MONSTER, HIGH FITS MND BY FAYS, and BORN TO GOOD IUCE were given. Mr. Locnerd, the Englith comodian; did not seem to better tters any, and on Deoumber 19, 1046, the sees on. closed with a benofit for 0 . F. Snlth in THE P. P. or THE MAN AND THE TIGER,

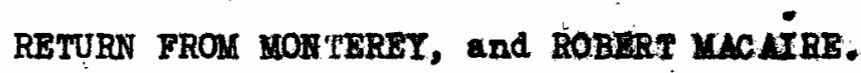

Thus the yeat 3846 saw the opening of the Loujs ville Theatre followed by one successful season and three which wore far from that. But years af that sort were frequent, and nothing deunted, the theatre continued, opening in Fobruary, 1847 with a coupany cauposed of somo of the formor favorttes including Mrs. Kent, Mre. Furren, Mr. and Mrs.C. T. Smith, and Mr. T. G. Booth. The entwaved pluyer at tho oporing mas a danserse named Mary smo Loo

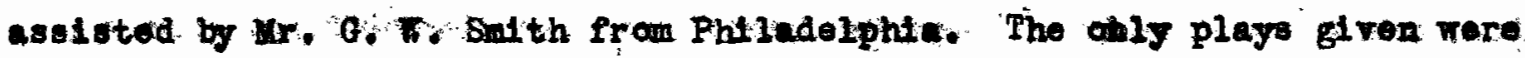
short ones, and in botiteen theil wore Given the dances such as La FIerr des Chemps, and the Carnival Bel1. M18s Leo boamo oxoggdingtypopular. Sho was a "neat, attractivo, small, IIght, groefal figure", and hor danoing ras a

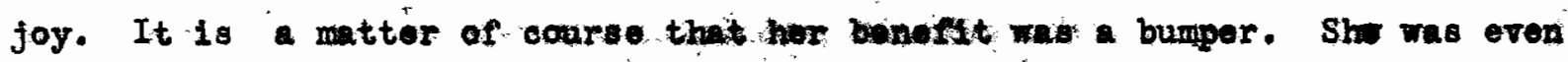
spoken of as "Our Mary inn", not only beowse of her popularity, but becuse that happened to be the ana of one of the dapoes in which ohe appeared. Following Kise Lee; Julle Dan plinyed an ongagenont beginning on February 17, 1847, with the HUNC FBick, Mise Dean wes one of Louls it116's: greatest favorites during this ontire porfod; for the pley-going publio

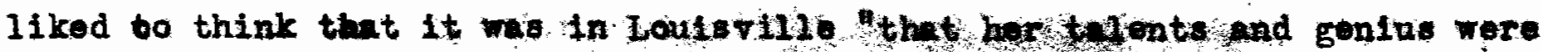


first discovered and encouraged". Daring this engagement ho played Mrs. Faller in THE STRUGER, Mergaret Elmore in LOVE'S SACRIFICE, Elvira in PDZARRO with Mr. Morris es Rolla. Biance in FAZIO, and Jultana intHE HONEMOON. Likewra she played LUCRETIA BORGIA for the first time in Louis in 110 , and she repeated the play threo times. This role becane one of Miss Dean's most effective parts, and one which she played many times on her various visits to the city. For her first benefit on February, 1847, she played for the first time Ion in ION. At that time she played very woll, but some of the company did the best they knew how to butcher the plece, for which "they were very deservodly hissed by the audience." Audiences in those days did not fail to express disapproval in that manner, and Lou is 11 le audiences were not slow to show their dissatisfaction. Miss Dean wes re-engaged after the benefit and played the VIFE, THE LADY OF LYONS, and HOMEO AND JULIET. The night ROMEO AND JULIBT was ploged the whole performance was for the benefit of the Starving Irish and the Poor of Loulsville. Miss Dean's engagenent closed on March 1 with another benefit. The remainder of that season was notci remarkablo. Barney Hilliams, the Irish comedian, did appear, but the company in generil vas so poor that it caused great dissatisfaction. One night, on March 11, the aucdience was very small and hissed at sompthing that occurred on the stage. The actors outnumbered thoir audtors, and, resenting the insult especially. since it was offered to a lady, engageditn what seems to have been a rather serious quarrel. The actors rere the riotors, and the paper on the next morning remarked that while the performance might have been worthy of such treatment, the acting of a roman showl never b. hisadedt.

The season closed in March 27, 1847, notwithstanding the fact that the famous actress and writer, Mrs. Mowat,, was on that very day in the oity, but she and Bates could not come to terms regarding an engagemont. Bates' arbitrariness in watters of that kind somewhat aroused the Louisville public, and it demanded a change of mankgement.

During the rominder of 1847 and hring 1848 there was constant 


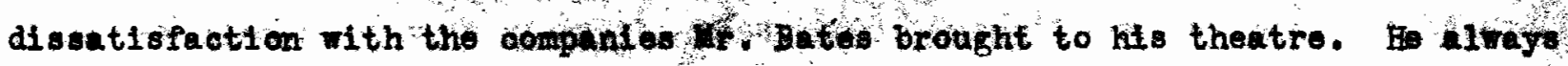
had several good performers, but all the good work that these could do ras ruined by the general lack of ability on the part of the other actors.

In October, 1847, Marble played an engagement,presenting his usual Yankee characters and in additon playing in A HOME IR THE FEST, which was thein a "popular new play by Colonel Bradbury, "for whose benefit the performance was given. A Miss reymss and her father lso played an ongagement, and tho. acting of both brought forth warm praise. Miss Feymss as Jullet was particularly pleasing, and "her enunciation wes the most perfect and her orthoepy was the most beautiful and corroct wo heve over heard from any femalo on the stage." Mr. Teymss as Morcution was considered superion to any actor who had played the part in Louls ville. November 9, 1847, Hackett was billed to appear, but for some reason he did not come, and he was expected bhethe next day. He still did not arrive, and the nemspapers came to the conclusion that another disagreement had come up botween the actor and Mr. Bates. Miss Clarke played an engagement during Deoember and was very pleasing in LONDON ASSURANCE as Lady Gay 8panker. In March, 1848, the theatre was reopened for the spring season, and charlos Gibbon Pitt was the main attraction. Among other fumous plays he presented RICHBLIEU in which he gave an adrirable imporsonation of the Cardinal.

On March $23 \mathrm{Mr}$. Bates had his first full house of the season when Henry Placide appeared in GRANDFAPHER WHI HEAD. Mr. Placide excelled in the performance of the character from which the play is named, and he gave a remaithly tme and accurate representation of the character. He completely lost himsale in the part, and the critic of the day remarked that "there was not a dry eye in the house." Mr. Placide and $\mathrm{Ml}$ brother T. Placide were very famous in their day, and the name of the Plabldos has come down throught the years as that of excellent actors and men. Tom Placido was later very famous for his Varleties which he organized and which existed for many years in New Orleans. 
In the early part of 4 pril, 1848, Edrin Forrest, one of the most famots American actors and perhaps one of the greatest of his day, appeared in a number of his parts in Shakespeartan plays. The theatre was very poorly attended, however, not only because of the rival attractions of a visit from Tom Thumb and Rockwell's Circus, but because Mr. Bates raised the price of admission to his theatre during Forrest's engagement. Certein of the press waxed very warm, accusing Bates of charging higher admission regularly than he charged at the thbatro in Cincinnati, and thon when good attraction did come to the Louisville theatre, of raloted the prices. Loulsville and Cincinnatt were great rivels, and the people of Louisville objected to paying their money to enrich the ooffers of the other city, for this they supposed happened, stomir. Bated had greator interests in that city than hore. One might go on indefinttely niming the plays that were producod and the actors and actresses who played in them, but it seems fitting and proper to deal fat the most part with those engegements whioh were really noteworthy and meant someting to the people of Louisville then and since that time.

There was a famous family called the Rarel Family who were expert gymnasts, performers on matcal instruments, and pantomimists who held the theatre for reoke with theị performances. The Batemenechtldren, BIIen and Kate, were little poople who assumed parts suoh as Shylock and Portia in THE MERCHAHT OF VENTCE. They were considered prodigies, and people flocked to see them as they did to see all the timy perfomers with whom the country was flooded at that time, for there wa vogue for chtldren performors at about the middle of the nineteenth century. wo other 11ttle giris who were popular here were the Heron children. The youngest of these children, Agnes, was but eight years of age when dhe tlizet appeared in Louis villo. In December, 1848, Mrs. Alexander Drake appeared es Madane Clermont in 1 MOTHER'S VENGEANCE in Mrs. Chapman's benefit. Mra. Chapman was Mrs. Drake's daughter. Mrs. Drake was in her dey considered probably the greatest tragic actress on the stage, at least ghe is placed very near the top of 
tho 11st. Fashington Irving in spodking of Mrs Drake in a lettor to Mrs. Villiam Jordan of London says, reforring to Mrs. Drake's professional merit, that he had seen her in the character of the Widor Cheerly and Mary the Mald of the Inn. "In both of them she appeared to me to equal the best simllar performers that I hare lately seen on the London boards." That letter was written in 1832, and the Duke of Saxe-Wetmar on his vist to Louisville in $1826 \mathrm{saw}$ Mrs. Drake play in MAN AND WIFE and pronounced her the "Siddons of the Fest" probably destined to become the siddons of the world. It may readily be understood, therefore, that when Mrs. Drake appeared at the theatre in 1848 she had attained wide fame, and found "the largest and nost fashinnable audience of the season." Thunders of applause greeted her upon hor entrance. In December she appeared as Bianee in FAZIO on the occasion of Mr. Harry Chapman's benefit. Mr. Alexander Drake for the first time in Loui sollle for six years appeared on the following night, December 22, 1848, as Richmond in RICHARD III given for the benefit of Mr. Sarzedes, the stage manager. Mir. Chapman played Richard.

The elder Booth appeared from December 23 to 30,1848 in numbr of his famous characters. His Richard III was spoken of as being full of genius and truth and nature and eterting energy from beginning to end. At the time of that engagement besides Richard,Booth played in A NEW WAY TO PAY OLD DEBTS, THE IRON CHEST, PESCARA, HAMLET, BERTRAM, and the MOUNTAINEERS. Bopth died on November 30,1852 , on board the steamer cheneweth enroute from New Orleans to the north, and the boat bearing his body passed Louisville on ancon

the second of December. Hermas sadily wissed in Louis ville, but not more than in the whole country, for he was a powerful actor, and one who did a great deal for the early American stage.

J. E. Murdoch, the tragedian, was a great favorite in Loulsville, and scarcely a season passed that he did not appear, and sometimes he appeared to fill more than one engagement daring season. 
1849, and lasting woek. It is oald thet he drow the largest audionce that had over been in the theatre oven though the prices were raised from seventyfivo cents in the dress circle and parquet to one dollar, and those in the second tier of boxes from thirty-five to flfty cents. Wacready played HALILET, RTCEELIEU, MACBETF; (In which he was ooneldered by Louisville critios to be greatest of all) THE STRANGER, WERWER, and VIRGINIUS.

In 1849 Asiatio cholera raged throughout the country, and the theatre felt the effeots of the opldemie. On Nay 10, 1849, Dan Narble, always a

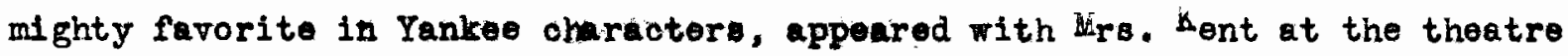
in SAM PATCH IN FRANCE, BLACK-EYED SUSAN, and DRAD SHOT. On May 14 Marble died of cholera the Louisville Hotel. Several other Fankee comedians played at the theatre in after years, but it seems that to none of them wes accorded the honor which Marble received. In hisplijze of acting hor was inimitablo. In October, 1851, Mrs. A. Drake with her son-in-1aw and daughter, Mr. and Mrs. Harry Chapman, opened what wa known as the Histrionic Temple on Jefferson Street bowreen Third and Fourth Streets. The Histrionio Hall belonged to a company of mateurs called the Histrionics, but Mrs. Drake used it for hor theatro. At first dramas such as FAZIO, MACBETH, and THE STRAHGH wore Given, but Mr. and urs: Chapman were both excellent comedians, and gradually the entertalments became a serles of short comedies, and finally the name of the thentre was changed to Chapman's Varieties. The enterprise lasted only until Deoember, for doubtless it could not bear competition with the Oriental magloian, the Fakir of stra, and the numerous concerts which were given. The most notable of the concerte were those given by Madame Parodi who was constdered a most excell ent singer, though not so fine as Jenny Lind.

James H. Fackett, who seeved to have hed difficulty several times about his eppearance in the Louieville Theaterded finaliy appear there on Apri1 1, 1850, as Fulotaff in HENRY IV. HAs Falstaff cannot bo too highly praised, and to this day Hackett portrayal of the jolly follow is a matter 
of history. Durlng this engugement ho aso played RIP VII IIMKLE, Himrod Wildfire in the KENTUCKIM, Falsteff in THE MERRY VIVES OF VINDSOR, Sir Pertinax MoSycophant in the MAN OF THE RORLD, YONSEEOR TOHSON, and MONSIEUR MALLET. He played practioally the same oharacters in December, 1853. The season whtch began on Jamuary 15, 1850, was very long one. It* did not end until May 18. The company was an excellent one, and wany $x$ players of note appeared thating that season. Mr. F. H. Crisp was the stage manager, and he and his wife played many parts, Mlss Eliza Logan and her father appenred for one weok, and both were well recoived. Julla Dean played two engagements one in samary and the early part of February, and the other one in Marbh. Louisville, then, for the first time sax Miss Dean's Lucretia Borgia in wll its power, and it was thought as "fine and as great a piece of doting as we have ever seen axbihtted by any lady on the American stage." Miss Dean's Borgie was ranked Wlth "Grisi's Normay Macready's Hamlet, and character by Rachel." On Febrary 4 Miss Dean appeared for the first time os Beatrice in HEE $A D O A B O U T$ NOTHING with Mr. Crisp as Benedick. On February 8, 1850, sho took a benefit in THE MRECKER'S DAUGHTER and FAINT HEART NEVER KON FAIR LADY. The crowd was tremendous, and two or throe hundred persons wore turned arry. This bonefit became theatrioal history, and was referred to later many times by ray of comparioon. Besides the plays mentioned, on this occusion, Miss Daan also played Madelaine in THE BELLE OF GHE FAUBOURG, EVADNE; PIZARRO, KATHERTNE AND PETRUCHIO, THE LADY OF LYONS, THE SOLDIER'S DAUGHTER, On her return in Maroh she played in FAZTO, the GAMESTER; THE SPAIIRDS IN PEE, and THE JELOUS VIFE, repeating IUCRETIA BORGIA. These worde of the oritic in the DAILY JOURAL tell of Julla Dean's power over an audience:" "She is not a mere machine, moving first one arm and then the other uttering meohanfeal things, but a creature of fiery genius and passion pouring forth her enotions from the depths of an overburdened heart." 
BII za Logan wes produced with Bor sookory and a rory Iarge oompany. Miss Logan was very popular with Louisville andionces, and they were glad to note the improvement and progreas which the young lady made in her careet on the stage.

The year 1850 closed with an engagement by charlotte cus hman, one of the greatest actrekses the Anerican theatre hed produced. Miss Cushman appeared as Mrs. Haller in THE STRAHGER, and the critic was right when he said that a finer Mis. Haller mover appeared hore. Many people had to hide their eyes to keep the teats from showing, so effecting was the portrayal, and this in the play THE STRUGER whi oh was never a very popular play in Louisville although it was given times without number and was in the repertolre of all the famous players. Hiss Cushman also played in AS YOU LIKE IT and other Shakesperian plags:ter

The season at the theatre opened in 1851 with an engagement of Murdoch, and the compang included the rory good actress, Mrs. Coleman Pope, and Messrs, Beresfd and Cliffotd who wore excellent actoro. Besides his usuel shakespearian productions Murdoch gave MILD OATS, MONET, TEE HONEYMOON, and THE STRAYGER. Mis Charlotte Cushman and her friend, Miss Hays, an English authoress, wore in Louisville in April, and, it was naturally assumed that Miss Cusban would eppear at the theatre, but she did not. S1lsbee, the Yankee impersonator, Pllind engegement, as did Flizaslogan and her father. Old Joo comell for the first time in seventeon years played in Lou isville in THE RIVALS. After that ho appeared here many tines both at the theatre and as an aotor assiating ambeur productions. Neafie, the tragedian, played in Juze offerting MOHAMED, RIOHARD III, ORALOOSA, OTHELLO, and DON CESAR DE BAZAN.

Mr, and Mrs. Howard, Mrs. Stanley (known to Loul sville playgoers as Miss Kaywood), Mr. Fleming, and Mr. Dawson were in the compeny of the Theatre during the season which ended on July 5, 1851 .

The theatre remopened on August 21, 1861, with Julia Dean and her 


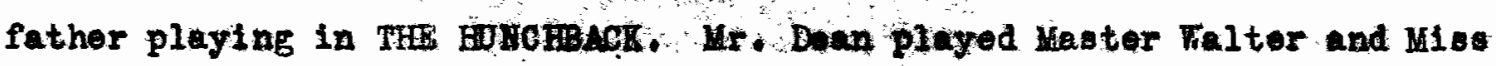
Dean, Julia. They played for month to orowded houses, and in addition to the roles she usually impersonated she offered Mrs. Beverly in the GAMESTER for the first time in Louisville, Florinde in the APOSTATE, Cabrielle de Belle Isle in the DOLE'S FACER whioh he played three times, and Adrienro In ADRIENNE THE ACTRESS. The 1 atter oharecterfeation called forth laughter, tears, and applause. Miss Dean was this time at the beginning of her career, and yet she mut have given some remarkable examples of acting, for Louis ville was not the only city in which she was adored. In 1852 sho appeared again, and for years she was perhaps the best loved and most popular actress Who appeared on the stage of the Loul oville Theatre.

In June, 1852; and again in April, 1864, Mrs. Inno cora Montt, played engagements, very suoceseful ones, at the theatre. The oritic of the Daily Journal remarked that she combined the naturalness of Mro. Kean with the power of Miss cushman. On her flrst appenrence she played in ARAND, a plisy written by herself, the HUMCBBACK, INCOMAR, LOVE; ION, AS YOU LIKE IT, THE BRIDE OF LAMMERMOOR, THE HONENOOON, ALL TEAT GLITTERS IS NOT COLD, TWELFTH NIGHF, THE. WIFE. Daring the engagement of 1854 Mrs. Mowatt played several of the same roles and in addition acted in FASHION, another play written by her, THE SCFOOL FOR SCANDAL, and took her benefit in the beautiful play KING RENE'S DAUGETER, and the IADY OF LFONS.

Beginning on October 24, 1854, E. L. Davenport played until Hovember 1. He played in THE MERCHANT OF VERIC E, THE LADY OF LYONS, HAMLET, OTHELLO, PIZARRO, BRTUOS, or the Fall of Tarquin, and ST. MARC or the Husband's Sacrtfioe. Davenport was very great in hls day; and his engagement was a very successful oxp.

It is interesting to note that Mrs. G. H. Gilbert, who for many years, fifty-four to bo exact, was very famous on our American stage as a delineator of old ladies, in September, 1863, was one of the company at the Louisvillo Theatre. She was not an actress then, but dancer, and she and hey mand 
performed the baliets or the danees betwed the two plays of the ovening which were an inevitable portion of the programme.

Ben De Bar, comedian, played at the theatre in October, 1854, as Mr. Timothy Toodies in TOODLES. Mr. Goorgo Van Denhorf in April, 1849, played an engagement, performing in the LADY OF. LYONS, OTHELLO, CATO, DON CESAR DE BAZAN, and HAMLET. Van Denhof also appenred in November, 1852, with Brs. C.N. Sinclair, formerly Mrs. Forreat. Those two men, besides being actorg of no mean ability, are interesting to Louisville people because several years later one of them, De Bar, gave Mary Anderson her first engagement outside of Louisville, and the other gave her her flrst lessons in acting and speaking.

One might go on almost ondlessly chronicling the plays and the players who appeared, byt that would grow uninteresting. The thoatre which existed in Louisville was mach the same sort of theated ex existed in the other loading cities of America at that time. The star system was the only posaible one, and by that is meant that each theatre had Its own company while the stars traveled from place to place performing with the companiossat the theatres. The length of the seasons varied; the seasons were usually theoe in number. Unless apparticular star happened to be avallable, the sumer season, if the theatre opened, was given over frequently to the production of spectables, to magicians, or to varieties. The varieties were the parent of our modern vaudevilie theatres. The most famous verieties which played in this city were Placide's Varieties. Placide for many years was the manager of the Varieties Theatre in New Orleans, and his company was famous the country over. They occupied the Louisville Thestre from August 5, 1850, unt11 Norember 2, 1850. The length of their stay indicated the popularity whioh they knew in the city. Many of Placlde's players were at that time famous and became even better known in later years. Goerge Holland, Mr. Dawson, Mr. Bas, Mr. and Mrs, Charles Howard besides Tom Placide himself vere of the company. Two young lady dancers, Wlies, Baren and Hilleriot, took the 
clty by torm with thelr dancing, Atrovaganzas such as FORTUNIO AND HIS SEVEN GIFTED SERVANTS, short comedies liked the burlette JENNY LIND, KATE KEARNEY, THE KISS IN THE DARK, THE FOLLIES OF A NIGHT, THE SERIOUS FAMILY, THE COCKNIES IN CALTFORNIA, and PET OF THE PETTICOATS along with dances and singing ade up the usual billo. Placide was a very generous souly and on August 26, he and his company gare benefit for the firemen. Mr. Howrard spoke an address. for the firmen, and he was presented by them with a silver loving oup. The occasion of Mrs. Howard's benefit was almost a repetition of the great benefit of fulia Dean. On September 30 ,Placide presented THE RIVALS in which ho himself palyed Bob Acres. His acting in that part was "a study", but the piece was sady out, and this was the only marring note In what must have been a notable performancef for Mrs. Howard played Lydia Langutsh, Mr. Howard, Captain Absolute, Mr. Holland, David, and Mr. Bas, Anthong Absolute. The benefits of every member of the company were "bumpers", and the two dancers each received showers of bouquets and wreatho as tokens of appreciation of their art.

Aside from the professional theatre, the amateurs of Louibville wore not idle. There were the usual dancing exhibttions of pupils of various teachers, and endless concerts in whioh favorttessingers of the city appeared, buit there were somerpersons actively ah work studying and producing plays. Just who these people were we do not know, for the names of the actors are not given in the advertisements of the playe. They are modestly mentioned by initials, doubtless feeling that it rould be too forward and bold to have their names appear openly in the public press. He wonder how the eager amateurs of to-day who scan the papers with oble eye for a mention of their "names in print" would feel if they knew that they were to be spoken of simply as Miss A. E. H. or Mr. H. O. It was customary in those days, the late forties and the early fifties, for unateuss to assume only the lesser roles and have legitimate actors and actresses for the leading parts. In 1851 we find mention of a performanoe of the Histrionics, "Louis\% 


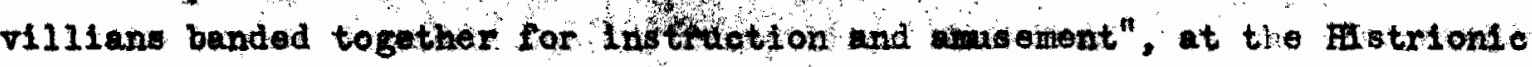

Hall on Jefferson Street. It was in this hall that Mrs. Drake and the Chapmans appeared in the same year. It wa sald of the first performanoe of the Histriontes that some of the acting would be creditable to oldestagers. On May 17, 1852, the Flstriontcs presented two plays, TFE BRIGAND and USED UP. The BRIGAND was so popular thit they repented thit pley in conjunttbon wh RAISING THE VIND four day later, The price of admission to the plays was fifty cents. July 12, 1854, ser the first produotion of the Louisville Dramatio Assoolation at lozart $H$ all. At flrat this association was oomposed only of gentlemen, but several years latex we find mention of the partioullrly excellent performances of the ladies in the cast which leads ue to suppose that ladies were later admited to membership. On the ocoasion of their first performance they gave LONDON ASSURANCE with Mrs. W. C. Gladstane as Lady Gay Spanker, MS A. C. Carman as Grace Harkaway, and Mr. Joo Coweil as Mark Meddle. The three persons mentioned were all legitimate actors, who may have been in the city between seasons at the theatro. The remainder of the parts were assumed by the gentlomen of the association. On-July 19, 1854, the same association presented Lotrbue's piay THE. STRMGER and the comedy BOX AND COx, Box ras played by Mr. Cowell. Tho prie af edmission wassserentyfive conts, and very naively the advertisombt calls attention to the fact that 1ce-water would be supplied at the Hell. The weather is apt to be very warm in July. The Loufsville Musio Association, composed of the muslelans of tho city, in 1852 gave monthly subeription conoerts at thelr hall on chestmits Street between Second and Third Streets.

Besides the hundred and hundreds of onoerts which were given at, . . that time (there never seemed to be night whout one) Louisvillo before 1885 could boast of four regular awowo of grand opera at its Theatre.

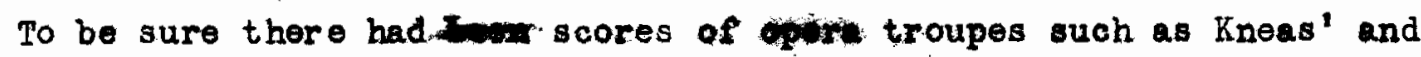
Kunkel's troupes, performing atmost whout intermission at the halls, but the seasons to which we refor were tewly seusons af grand opera. 
The first abson began In Jin, 1880 , Heasieur Fiot was the manager of the company whtch was knom as the Fronch Oporattconoengany. Madame Doyrtos was the prime donna who later appeared with the Italian Opera Company and was oalled Signora Rosa Do Vrie日. Madame Devries was an excellent actress ao well as a splendid singer, and he wa alugge received, in Louls ville with the greatest approval, and oneone occasion she wes tendered a complimentary benefit by a number of the most influential cltizens of Loulsvillo.

The operas which the French Operatic Company performed were THE PROPHET, THE FAVORITE, THE OATH, THO FOSCARI, LILI DE CORRERARA, NORMA, JERUSALFM, LUIN, and BOBERT LE DEALE.

In 1851 for two weeks in May the Seguin Opera Troupe occupied the Theatre. It was their custom to play an opera folbewed by a play by the regualer company at the theatro. They gare tro performances oach of

LA SOMNABULA, THE BOHEWIN GIRL; THE BARBBR OF SEVILLE, CINDERELLA, THE GHID OF THE REGIMENT, and one performance each of FRA DIAVOLO, DER FREISCHUTZ, and NOFM.

The Italian Opera Company under the direction of Signor L. Arditi played one season in Angust, 1853, and another in June, 1854. It seems to have been the oustom af that company to prosent an opera only erery other night, but in the course of those two seasons were presented the most popular operas of that day and many that have ourvived and are given each year in the great opera houses of Amorice, They gave EFAANI; NORMA, LDCIA DI LAMERMOOR, LUCRETIA BORGTA, IA SOMMMUAS, L'ELIXIR D'MORE, BELISARIO, DON GIOVANNI, and thOEAARBEROOE DETLLE.

It mast be said for Louịille audiences of that day that they patronized the opera, and the artists presenting it were welcomed. The prices for the Italian Opera company wore fixed at one dollar and fifty cents, one dollar, six dollara for the entire season.

From 1846 until 1855 the Louisville Theatre know many stage managers, but the one man holding that postion most froquently was the flrst one, Mr. 
Sarzedas. Often, horever, the stage manager was one of the members of the company like Mr. Milon, Mr. Chapman, Mr. Earry Tatkins, or Mr. C. A. Logan. The proprietor remained with Mr.J. K. Bates or Mr. John Bates until November, 1854, when the name of Bates ceases to appear in the Theatre notices, and the name of George Mellus is given a the manager,

Early in the fifties the theatre was given a new drop-curtain, and the audiences coased to upon the beautiful dome of the Capitol at Tashington. The seating arraggements were changed by 1849 ; so that there were no longer the so-celled private boxes, but the dress.circle and the parquet. These seats were pricéd at serenty-five cents, the secdnd tier of boxes wer e thirty-five cents, and the gallery was twenty-five cents. - The time for the opening of the elegre varied from seven o'clock during the winter, to eight o'clock in the sumer, and the doors of the theatre were opened usually one-half or three-quarters of an hour before the curtain rose.

When one considers the competition offered the theatre of those days by circuses, concerts, floating theatres, minstrels of every name and desscription, conjurers, dramatic readers, freak masums, and panorame, one almost comes to the conclusion that amsement life in those days was a very complicated affalr, and that an actor or an actress mist needs have been very fine, indeed, to attract large number of persons to see a performance pf a play which had been played so frequently (as most of the popular plays were) that the hearers must harelinown the lines almost as well as the actors. Fe have reserved one great orent in Louisvillo's history to be spoken of last in this ohapter - Jenny Lind's concests. Jenny Lind was not an actress, but her singing in Loulaville annot help forming a part of the history of the theatre of the city even dothis spoken of with pleasing . remembrance in every other sort of history of Louisvillo.

In October, 1850, Louisville heate thet Cincinnat1 had prospects of securing Jenny Lind to sing in a "plank structure, the inside of which was to be IIned with cotton fabrice." Loulsville, not to be outdone by her 


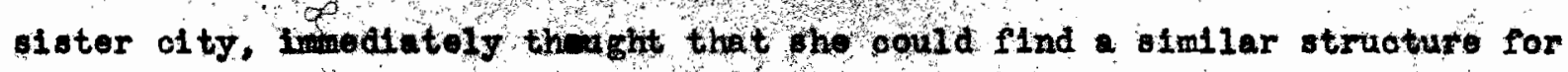
the famous lady or perhaps a better ond It will be recelled that Mr. $P$. T. Barnum was Miss Lind's manager for her tour in this country. Plans were set on foot and arrangements were made, and on March 18, 1851, Mr. LeGrand Smith, Barnum's private secrotary, wa in Louisvillo making final arrangements for the concert which was to be held on April 7. Mozart wall welected as the most suitable place for the concert, and from that time on until the appearance of the "divine Jenny" Louisville was agog and alive with expectancy. Jenny Lind furniture, Jenny Lind dresses, hats, coats, and even vestswere the order of the day. The editor of the Daily Journal, Mr. Prentice, was presented by Mr. Tolf Samuels of the Mammoth Clothing Depot with a vest called the Jenny Lind Vest. The editor remarked that he would wear the vest on grery oocasion when he visited Miss Elnd or went to hear her sing. Miss Lind was expected to arrite in Louisville from Nashoille where she had gone from St. Louis. On her way from Nashville to Louisville sho visited Mammoth Cave. The Louisville Hotel was undergoing extensive repairs at the time, and so arrangements were made for Miss Lind to remaind during her stay in Louisville at the home of Mr. L. L. Shreve at Sixth and Tialnut Streets. The orohestra was housed at the Hotel. C. U. Shreve, a young nephew of Mr. L. L. Shreve dotermined thet Jenny Lind should have a royal reception in the city. With three friends, J. Frey Lawrence, Drs John Matthews, and George H. Croghn (whose uncle owned Mammoth Cave) he set out to meet Miss Lind at the Cave. The young gentlemen drove a handsome equipage drawn by four bay horses belonging to the elder Mr. Shreve and to Mr. Lawrence's father. They made tbolr first start from the Galt House at four o'clock in the afternoon several days before Miss Lind was to arrive in the city, but they had gone only few squares when the horses ran into a dray, the oarriage was overturned and broken, and the provisions spilled all over the street. They ware oompelled to use another carriage when they started again on the folloring mowning. This time it was a closed 
conveyance whioh the horses oansed to tumble oner an emankment and gave tho travelers good fright and goneral shaking-up, After that mishep the trip was made in good order, and the young men covered ninety miles in tays. Upon their arrival at the care, they were permitted to meet Miss Lind, and they were somewhat diappointed to find that she was not beautiful atlall when her face was in repose. They socn discovered, however, that when she sang or became animated, the expression on her face was ronderful to seo. They accompanied Miss Lind through the Mammoth Caro, and would have peroudied her to $\mathrm{sing}$ in the Star Chamber had not the over watchful Barnum agent prevented the song. On the day following they drove their carriage home in company with the one in which the famous singer was riding.

On Friday, April 5,1851, Mr. Smith had arrived in Louisvillo by stage from Nashville while Mr. Barnum find the remainder of the company with the exception of Miss Lind, her secretary, Mr. Benedict (the orchestra leader), and Signor Bellett1, a soloist, came by steam-boat. Miss Lind and her party arrived in Louisville on Sunday. Immedialely upon her arrival

Miss Lind went to $\mathrm{M}_{\mathrm{r}}$. Shreve's, and for "a long time after her arrival hundreds of persons were assembled in front of the house, and other hundreds walked and rode by, all no doubt hoping to get a glimpse of the divinity gratis." (Daily Journal - April 7; 1861.) Mr. J. Katthews had some spocial Jenny Lind furniture for her apprtment. Two artioles wore a papiermacho inlaid table and centripetal spring chair. During the course of the day "Mr. Shreve was seen walking with Jenny in his beautiful garden presenting the most exquisite flowers to her with all that gallantry of manner th which none oren of us young folks can surpass him. Ho is the envy of the whole town." (Daily Journal - April 7, 1861.)

On Monday morning, April 7, the auction of the seate for the conoert took plece at Mozart Hall at ten o'clock. Ten cents admission was charged to attend the action, in order to prevent ldle curiosity-seekers from oocupyling foom meant for possible bidders. The money realized from the auction. 
tickets (As was the custex In all the Lfind concerts) was turned orer to the Mayor to be used for charltable purposes. The amount given to the Mayor of Louistillo amounted in all to elghty-two dollars and fifty cents. The price for a concert ticket was flxed at five dollars, but Mr. Iripp paid one hun dred dollare for his ticket. This was the highest bid for one of the tickets in Louisville. (Ur. C. U. Shreve in the Courler-Journal in 1901 made the statement that Mr. Lewis Trupp patditwodhihdreds and twenty-five dollars for his ticket, but thi bove flgures are taken from the morning paper on the day following the sale). Sirty tickets at three dollars each were issued for standing room. Mozart Hall visually hold about six hundred people, but it is said that there were at least twice that number in the auditorium on the night of Jenny Lind's first concert.

This thethe programerfor the fifst Jenny Lind concert in Louisville on Monday, April 7, 1851, at the Mozart Hall:

\section{Part I.}

Overture -..- La Dame Blanohe --..--Boteldiou

Aria - - Sorgate (Maometto Secondo ) -.. Rossini

Signor Belletti.

Aria -- Perche non ho del Vento - -Donizetts

MIle. Jenny Lind.

Fantasia for the Violin - II Tremolo -- De Boriot.

Mr. Jokeph Burke.

Trio for Volco and two flutes (Camp of Silesia) composed expressiny for

M1le. Jenny Lind -...-...-Heyerbeer."

MIle. Jenny Lind.

Flutes -- Miessrs. Kylo and Stede.

Part II.

Overture --- Fra Diavolo - - - - - - - buber.

Caratine -- Largo al factatum (Il Barbier) -- Rossini.

Signor Belletti.

The Bird Song -

MIle. Jenny Lind.

La Tarantella Napoletana -....... Rossint.

Signor Belletti.

Ballad -- Home Sweot Home - - Bishop

M11e. Jenny Lind.

The Herdsman's Song - comonly called the Echo Song -- Swedish Melody. Mlle. Jenny Lind. Conductor Mr. Julius Benediat.

Orchestra conducted by Mr. Joseph Burke. 
Lind. Those who had heard her were inglng ber pratses to those who had not, and the news tent fonth that he was to give second and yet a third concert. The paper for the day contalns lengthy article discussing the merlts of the singer. The oritic of the Daily Journal asks "who ever heard Home Sweet Home until last night?" In regard to her singing the same critic says, "Every tone is pure and finishod, the highest is reached without effort. and the lowest sends its tiniest ripples into overy corner of the roon. Critice have called Jenny's singing cold and passionless, but we know nothing of the meaning of such termo when applied to her. To us her singing seems the purest of intellection, chastened by a faultiess taste, and warmed by a full and true appreciation of her art." Every plece was a joy, and Jenny Lind was Lou isville's idol, as sho was the idol thovery city in which she sang. The seoond concert was given of Fedriesday, April 9, 1851, and at that time Miss Lind sang:

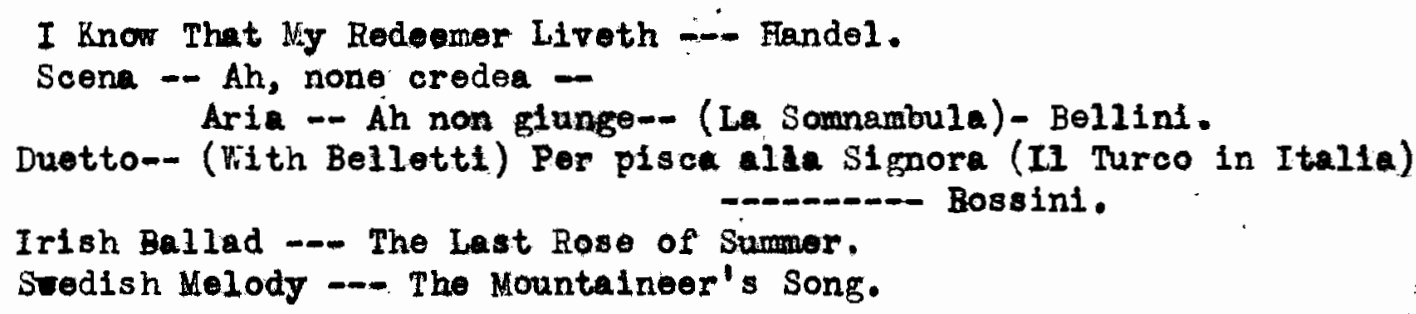

Speaking of the rendition of "I'Know That My Redeemer Liveth" the Daily Journal critic says, "We now foel that we have heard a specimen of the composition of the greatest of all musical composers sung by the greatest of all vocalists, and it is something for the memory to cherish with undying affection. Tie have heard the triumphent faith of the resurrection of the body expressed in tones of purity that are almost angelic in their sublime sweetness and harmony". The oritic atco remarks thet in the scolding scene with Belletti,Mis8 Lind looked so weet that it might encourage husband to have fits of anger every dey.

But the"Last Rose of Sumer was the croming glory of the second concert, and she was compelled to sing it twice. She sang it in such a manner thet "her singing was equal to the poetry." 


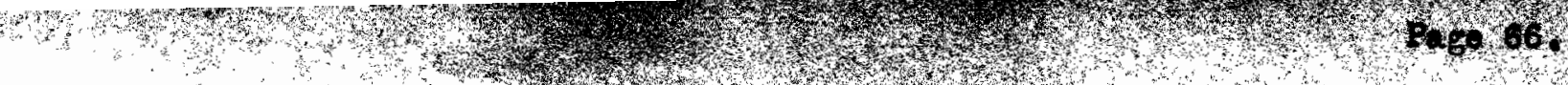

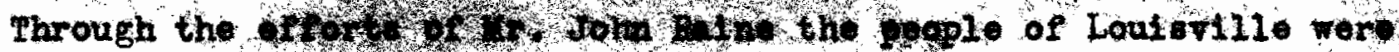
glven anothor opportunty thely 10 to hour Mis: Lind. On that ocoasion

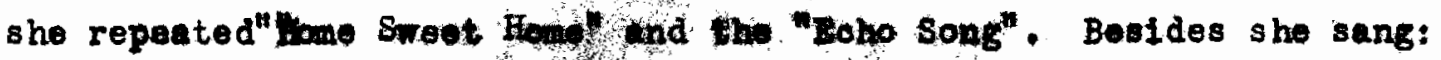

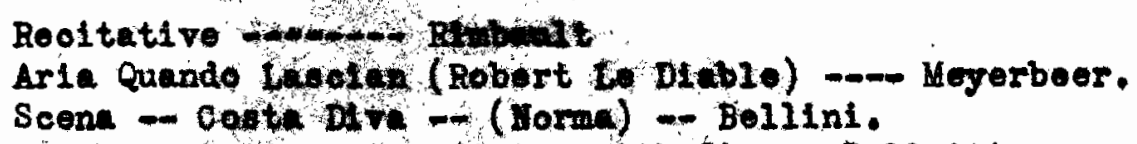

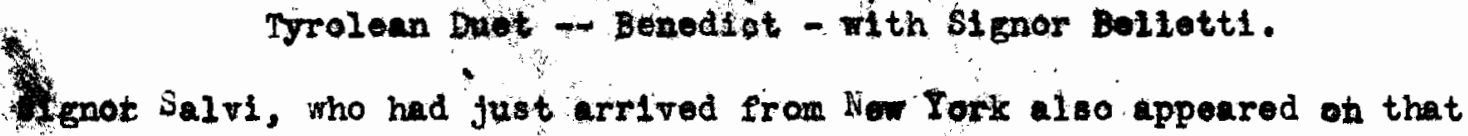
programe, which was in sew reapects the richest of tho sorles.

On Friday morning, April 11, Jenny Lind and her party took leave of Louisville. Ihey left on the mall-bout "Ben Frenklin" for Madison, Indlana, whore she sang on the same night." Abeut one hundred citizens of Loulsvilie, not satisfied with hoaring hor in Louisvillo, wade the trip to kadison to hear her onoe mores fundreds of people of Louistille went to the river to wre good-bye: to the famous lady, but there was no undue excitement. As the boat pulled out from the wharf it hoisted tho Swedish flag and fired two guns.

Thus did Jenny Lind tale her leave of loulitille, and her concerts became history, memorfes lovingly chertahod and spoken of almost throoquartors of oentury leter. 
CH $A$ P T ER IV.

?

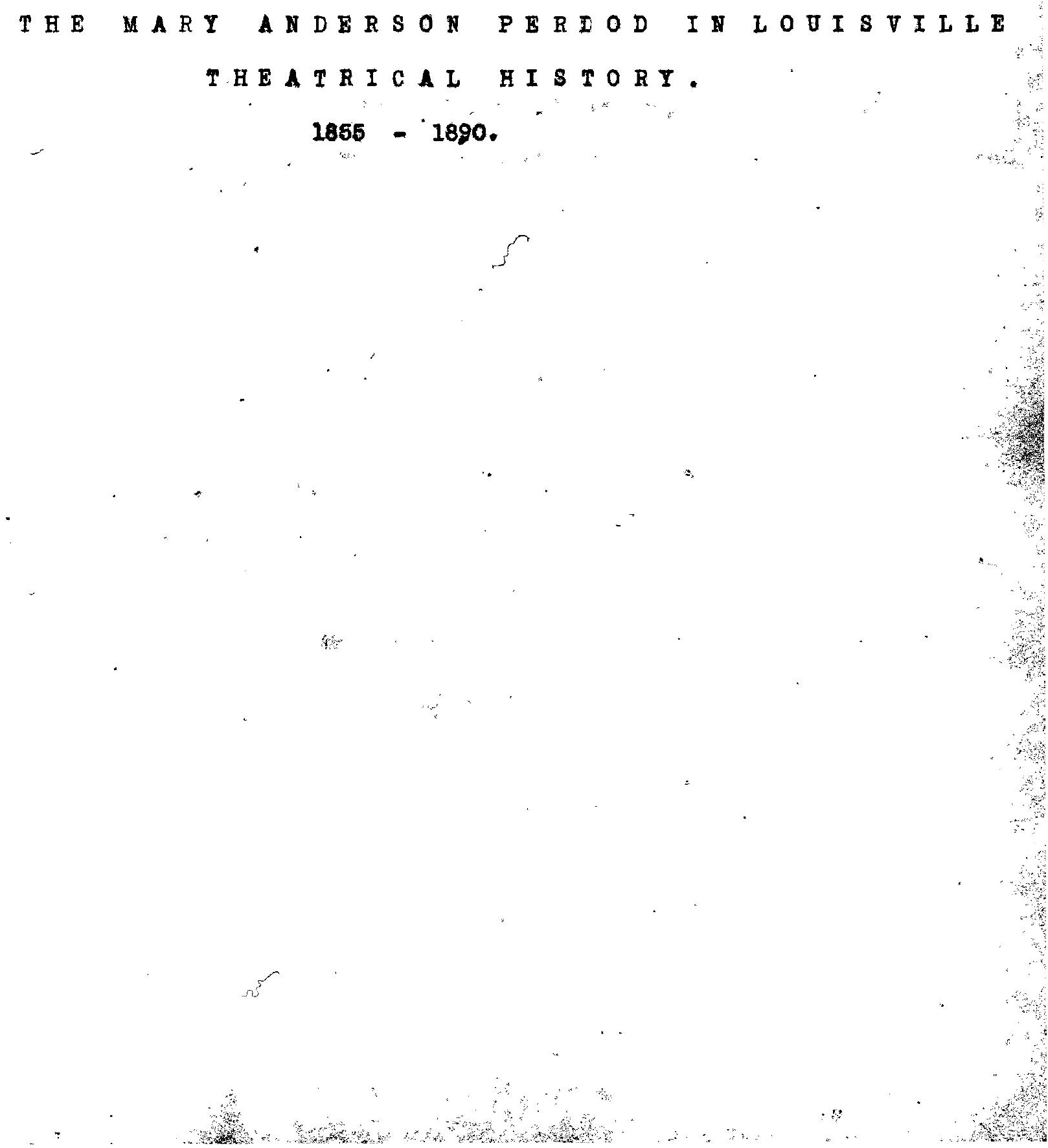




\section{CHPTER IV.}

THE MART ANDERSOI PERIOD IN LOUI SVILLE THEATRICAL HISTORY

$(\mathbf{1 8 5 5}-\mathbf{1 8 9 0 )}$

It is sometimes sald that the early part of the nineteenth contury was the golden age of the thextre in America. That was the time when actors like Junius Brutus Booth, Edwin Forrest, Macready, James H. Hackett, and actresses 11ke charlotte cusman dominated the stage and held their audiences with the mighty power of thelr geniug to provoke laughter or tears.

But the eurly part of "the nineteont/f century, at least unt11 the fifties, could hardly be called the golden age in the history of the Loulsville thatre. Loussville by 1850 was just well on ber way toward being a thentrien center eren though she had had theatre for mang yerers and had seen many, and Indeed most, of the theetrical stare of the times. Praveling conditions, were in a measure responaible, for the difficulty in moving from place to place was so great that only the hardieat would attempt it. But to one who has studied Louisville history, the yeare from about 1855 to. 1890 are filled with interesting information, and the student sees that Loulavillo had rílfilied the prophoog which the interest in her first theatro showed. The Louisville Thatre was the helght of 1 ta careier as playouse. Before and during the C1vil Far playhouses oprang up one after another. Some of these theatres had very brief existences, some had their names ohanged and ro-changed almost with the seasons, but ono or two, like the Loulovile Theatre, Masonfo Hall, and for awhlo, Moxert Enll hold their places as the leading pleoes of amuesmat for Loulaville thentre-goers.

Another reason for caling this pertod the golden age in fontsifllie drate history is that at this time there appeared in Louisvilie most of the artistiwo are considered the greatest and best representatives of the dram in merica. John Mocullough, Mr, and Mrs. Tallack, Joseph Jefferson,

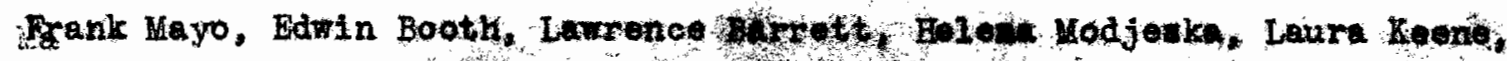




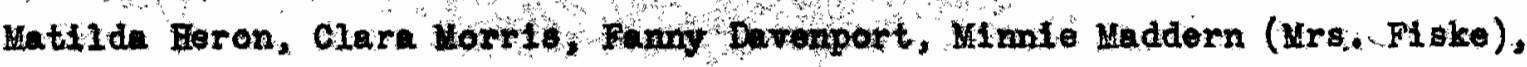
Maggie Mitcheil, Lotta, Ade Rohon, Aary Anderson-Louisville know and loved them and many, Imany other actors and potresses of that rich day in the American theatre. Besides mutize American players Louis vilie had visits from Foohter, Salvint, Bernherdt, Mrs. Langtry, whoweond the city ready to receive them and their work most latndiy.

Besides the cotual theatre, Lou is villo during this period knew a great variety of amsements. There were the circuses which brought joy to the hearts of the chlldren, and the specteoles like funpty Dumpty and Aladin and His Tonderful Lam. The olrcuses ohanged their places for exhtbiting as the city grew in 8120 ard rere no longer to be found almost in the center of the town, but farther away where the wases weire not so close together, at Sixth and Kentuoky Stroots, at Brook and Kentucky Streots, and at Eclipse Park. Dan Rice's circus during the fiftiof as well as during the forties was rery popular as was Spalding and Rogers Cirous. In the sixties and the seventies came John Robinson's Circùs, Cooper's Menagerie, Haight and Chambers Coldesal Southern Circus, Fourpaugh's, Van Ambrugh's, Barnum's, and during the eighties, Buffalo Blll's Wild Nest show, drew may mandreds of speotators. Sometimes the elreas or the menagerio vias housed in the Industrial Exposition Builalne wich stood on the corner of Fourth and chestnut Streets. At cortain seasons during the year the Louisville Theatre, Mozart Fal1, Reisiger Hall, or any of the pluces of entertainment, were occupled by traupes of variou kinds. Sometimes thoy rere pantomime troupes like the famove Ravel troupe, than which none better has over existed. Gabriel Ravel, the head of the organization, was one of the best pantomimists the American stage he ever known, and he vergopular in Louls ville during this period as well as during the preceding one. Other famous troupes of the time were the Martinott1-Blondin troupe, Lydie Thompson's Burlesque Troupe presenting offerings such a BLUEBEARD, SINBAD, LURLINE, the FOx 
Ballet Troupe, at othors Ameo the tioen of opera Bouffe, which charmed

Louisville eudiences. During the seventies and eighties Tony Deniersand Tony Pastor's troupes were very popular. Both of them included HUMPTY DUMPTY in their offerings, and the Denier troupe included the great Grimaldi Adams, or Grimald as ho'is best known, one of the most famous clowns in history. The minstrel troupes vere without end in so far as numbers go, but Campbell's, Birch and Bovers, Birch and Donniker's, Newcomb's, and Armstrong Brothers' were seen in Lout oville theatres most frequently.

The lovers of opera in Louisville between 1855 and 1890 certainly had an apportunity to gratify their tastes for the best that the musical world of the time had to offer. Each season sew sheleppenrances of at least three or four opera companies at each of the theatres, and sondtutbs the number far exceeded that figure. There was Engitsh, French, Italian, and German opera. The name Strakosch figures largely in the names of the companies which played in Louisville, sometimes in the Strakosch Grand Concert Company, and at others as the Strakosch Italian Opera company. The Parodi and Kellogg companies, the popular Meceull company, and the Abbott Opera Company played sometimes twice a season at eech of the theatres during the eighties. Alice Dates who came from Loulspille hoaded a company which was always more than welcome. In 1872, when the glory of the old Louidille Theatre was departing, Strakosch's company with tho famous Christina Hilsson played for period there. Cooper and Pyne's and Harrison's Engliah Opera companies, the Now Orleans English Opera Tompa all presented series of operas at Mozart Hull, at the Theatre, or at the Hasonic Temple. The Holman Opera Troupe and Gran's Italian Opera company were in Louisvilie often, particulariy during the sixties. During the seasons of 1873-74, 1874-75 Louisville supported entire seasons of Germanogpera at Llederkranz Hall, Many well-known operas, in fact all of the famous, ones, were performed, and the mat heve been well patronized, else the singers could not have contined tholr work. Some of the singers in the compeny were Anme Jueger, Borthe Roemer, and Carl Beetz. 


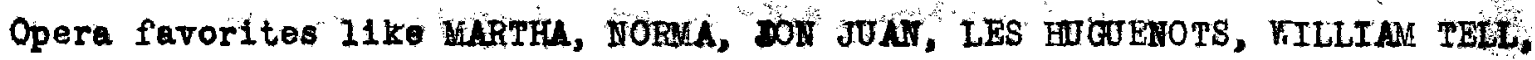
UNDINE, THE BARBER OF SEVELLE, THE JEVESS, BLUEBEARD, FIDELIO, MASANIELLO, and DER FRIESC HUTZ were presented.

There were concerts and lecturss upon all sorts of subjects in abundance. Adeline Patti, who had mede her first appearance in Louisville years before with 010 Bull, sang in the elty at two different times in 1860. She gave two concerts in June at Hozart Hall and two in November at the Hasionic Temple. She was here again in 1881, and wang in what was then called the Opera House (Vieisiger Hall). At that timo she gave one act from FIIST as a part of her programme. Ole Bull continued to be the favorite he had been during the previous poriod. Ho played in concerts in Louloville in 1869, in 1872, in 1873, and in 1877. Blind Tom, the negro musfeian who became famous all over America as pianist, played the Masonic Teaple in 1861 when he was but ten years old. He teturned at intervals and played in many concerts. Christine Nilsson, The Yale and Princeton College Glee Clubs gave concerts with which the Lou isville music-lovers were highly pleased. In 1881 Remenyi, the viollnist who was then taking Amertca by storm, played at the Opera House. One of his concerts wis given for the beneftt of the Louisville Flower M1ssion. On December 6 and 7,1869 , Theodore Thomas and his orchestra gave their first concert at Heisiger Hall. For years following the Thomas . Orchestra concerts were an institution, and sometimes the musicians appeared at two different times during the year.

In Jily,1877, Louisville held a Halcel Festival at Exposition Hell (Fourth and Chestnut) under the direction of the North American saengerbund 1 which was great success. One of the most interesting of the lectures must have boen that in whoch both Mark Twain and George F. Coble participated at Llederkranz Fall in 1885. Robert Ingersoll also lectured at the Opere House (Felsiger Hall) in 1878.

Of amateur performances there was nover a lack. Besides the annual exhibitions of schools, mulo techers, and dunctng clases there vere 
:

number of active ambens soefotios thich presented plays at carious times daring the yeur. In 8865 the Louisville Drametic Association was very active. They presented plays at four different times during the year, using Mozart Hall as their theatre. They offered such plays as THE HONEMOON (which,it is interesting to note, $\vec{t}$ the University of Louisville Players produced in 1918), BOX AND COX, DON CESAR DE BNAM, and LONDON ASSURANCE. The Plokwick Cluby the Farmony Dramatic Club, and Saint Bridget's Literary and Dramatic Clab were active for many years and presented plays which must have been really worthwhile. - The Dickens CIub was represented by its plays for many years, and frequentiy the proceeds of the performances were given to the Louisville Widoms' and Orphans' Home or devoted to similar charlties. The Minerve Soolety wa company of amateurs presenting plays in German. The Prentice club devoted ali the procesds from its plays to reliof of the poor. It was their custom to sezl the seats for the performances at auction. In 1880 at an action of the seats for one of the plays of this club, Mrs. Sal11e Ward Armstrong paid large sum of money for several seats and thon roturned thertickets to be resold. The Prentice club presented among other playe ALL THAT GLITPERS IS NOT GOLD and oORS. Tho Fialstaff Dramatic Club was activo in 1876 and 1877 presenting such plays as THE LOAN OF A LOVER, CAMILLA'S HUSBAHD, THE RGIT DAY, and PYGKALION AND GALATEA. The Garrick Club in 1878 presented CASTE at Nacinley's Theatre for the benefit of Florence Mitohell. On Septimer 15, 1876, the Mago Dramatic Olub offered a pretentious productlan of the MARBLE HEART at Pub1 ic Library 11. The calcium effects were by Professor Tobin, and the costumes by D'Arey, whoever those then illustrious personitges were. The Pythin Dramtlo Soclety offered the great favorito of those days, TEN NIGHTS IN A BAR-ROOM.

Masioal organtzations abounded. There rise the Mendelssohn, Beethoren, and Mozart, Cands Symphong Clubs in addition to the the Liederkranz and 011vetto - Societies. In 1882 at the Mesonie Templo The tre the Olivette Society gave 


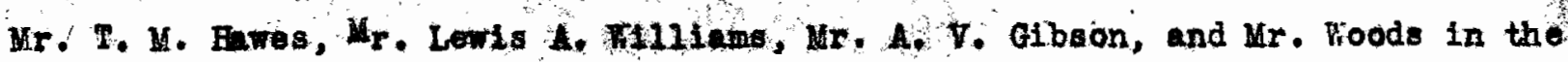
cast. In 0ctober of the same year the Prentice club gave a performanoe of tho immensely popular PINAFORE.

Several of these clubs lasted for many years, but some came into existence and passed out again in very short time as is the way of many organizations. They served their purpose, however, for during those years, when there was so great an abundance of amateur organizations, Louis ville was fully alive to all that was best in matters of the theatre, and the organizations with the funds secured from their performences doubtless did a great measure of good.

At the beginning of thas period, 1855, there were three particular places of amasement which were then active in offering attractions to the public of Louisville. These places were Kozart Flall, the Masonic Temple (after 1857), and the Louisille Theatre. These three theatres were all 10cated within fer steps of each other; the first two were located near Fourth and Jefferson Streets, and the last one on Fourthiand Green (Liberty) Streets. ,-

Mozart Fall had boen long a favorito place for amataur theatricals, for concerts, for apera and minstrel troupes, and for exhibitions requiring the use of falroized anditbotale. In 1860 it vas fitted up as a regular theatre and was openod in February of that year under the management of Benjamin Dufficid with George J. Griffiths as tage manager. Th. B. Erskine was the lessee. A regular stock company ras omployed numbering among its members Mrs, K. B. Daffleld, Miss Mary Ann Mitchell, Urs, Maddocks, Mrs, Lewis, Messre. Mitchell, G. Lewis, Falter, Keoble, J. G. Ashmer, J. Y. Collier, J. A. Martin, McCollum; J. G. Germon, and J. Ogden. For several seasonsthe theatre, or the hall, presented pleys of conslderable merit, and it housed attractions that drew good audiences. In Jizy, 1868, Chapman's Varieties played in the Hell for a season, and during thts time. Itttle Ada Blanche Chapman, the daughter of Mr. and Mrs. Farry Chmpman and the gratddeughtor of Mrs. A. 


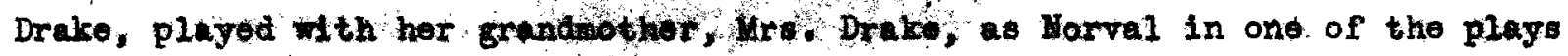
which the elderly uctress presented. Several yoars later, about ten to be exact, the little Blanche whin her sister Ellaswe the famous Chapman Sisters who were so very popular in the west and south and throughout the country. Mozart Hall contimued as a variety and intermittent legitimate theatre unt11 1863 when it was opened as Hoods' Theatre, pilled after the Cincinnati theatre of the same name, and under that title it saw its greatest glory as a thegtre. Foods' Theatre openod on Maroh 16, 1863, with a production of THE SEVEN SISTERS. Lottl Hough and John MaDonough were in the cast of the play which ran for several woeks. The first season ended on June 6, 1863 , and mut have been on the wholo a very successful one. It was during this first season of the Hoods' that Louisville was made acquainted with matinees. One of the papers very quaintiy remarks that fince the performances were given In the afternoon, they shoilld not be called matinees. It was not long until the other play-houses were likewise offering tinee performances.

In the course of its existence this old theatre saw upon its stage many of the nost famous and popular players of the time. Barney Macaley, Kate Denin, Cecile Rush, Kate Reignolds, John E. Orens, Joseph Proctor, the Kebb sisters ( and Ada), the Fesiterns (Luclile and Helen), Mr. and Mrs. Foiler, Matilda Heron, Leura Koon, Edwin Adams, j. Wilkes Booth, Lawrence a Barrott, afrs. Farren were a few of the really great players who visited the theatre and played there during its somewhat brief existence.

iuring Dariagetha season of 1866 and 1866 tho Foods' was under the management of Duffield and Flynn who also managed the Nashville Theatre. In the spring of 1866 Foods' Theatre became the Acaderny of Music, and for a short 'time it continued to function as a theatre. In the fall of that year when the old Louisville Theatre burned, thesstock company at that theatre was renoved to the Acadery of Music until the new theatro was ready far socupation. In 1868 the Academy of Music becume the Theatre comque, and not long thereafter it ceased to exist as one of the wath whle places of armsement in Lou is ville. 
The bullding mo finaliy dettroyed by fire, and a commercial establishment known as Oak ll took its plaoe.

The Masonic Temple at the period of its beginning in 1857 was hardly a theatre. It wa simply a hall where all sorts of engagements were played. It offered place for performances by magicians, opera troupes, minstrel troupes, Swiss bell-ringers, dramatio readers, and an accesional curiosity exhibit Tom Thumb atd his company appored there in 1862. In 1863 Artemis Tiard gavo his 60 MINUTES IN MERICA the Mesonic Temple. In 1878 the hall was converted into a gemuine theatre with inclined floor, boxes, a balcony, and a wide stage. One was alyays, however, forced to climb a long flight of stairs to reach the theatre. Daring the eighties the Masonic Temple Theatre was under several managenents, one of which was the Bourlier brothers and another Colonel W. H. Meffert, and it was rented to visiting road companies as they happened to come to the city. Colonel Meffert assumed complete control of the theatre after ho had been its manager for some time.

The Masonic Temple in the heyday of its careet during the eighties housed many notable productionsand many famous players. Barnoy Hacauley played there several timos. The Bmma Abbott Opera Company, Alice Oatarand her company, Thatcher, Primrose and Tes't's Minstrels, the McCaull Opera Company, the Strakooch English Opera Company, MoIntfre and Heath's Minstrel's, and Tony Pastor's Troupe were few of the companies which came there. Famois musicians like Remenyt, Lillie Lohmann, Franz humel, and Joseffy played and sang there. Famous players 1ike John T. Raymond, Fanny Davenpoet, Edwin Arden, Stuart Robson and Filliam H. Crane, Frank Mayo, Janish, Janauschek, and Josepp Jefferson appeared there in plays which had made their names celebrated.

The real theatre of the late fifties and the sixties was of course the Lou isville Theatre. In it performed most of the famous actors and actresses of the day, and if they chanced to perform at any time in one or another of the playhouses in the city, the noxt time they cane to Louisvilie they were. 


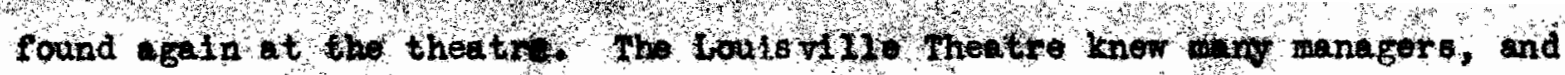
at least twioe during its extatence it wes manged by molinen. In 1860 Mrs. Mary Lorton followed her muband as the lessee and mager of the theatro, and in $1865 \mathrm{MIs}$ Leo Hudson, famous for her performances of the great play MAZEPPA, was at the head of the theatre.

An enumeration of the actiprs and actresses who appeared an the stage of the theatre would merely bo a list of practically all of the famous playors of the period. The stock companies at the theatre seem to have been of a fair degree of excelience, und some of them mist have been exceptionally good. Several players like Marcu more, Barney Macauly, and $\mathrm{F}, \mathrm{J}$. Scanllan were at different times in stock at the Louisville Theatre.

During the sas on of 1858 and 1859 the following rules regarding the sale and purchase of tickets were laid down by George Mellus under whose manage Jment the theatre was really excellent. The rules are:

No. 1. No seate reserved more than one dey in advance.

Nuo. 2. Bax office open precisely at ten A. M. by the Catholic clook which was in full vie of the Theatro.

No. 3. No seats reserved or engaged tet night under any circumstanoes.

No. 4. Thuber of seats reserved on each bench to be according to tho greand floor plan of the theatro; the purchaser to pay for and reserve as mung seats as he chooses "whether the number of his. party be equal to the number of seats orenot, thus allowing for any ampiltude of skirt necessary."

It will be recalled that those were the days of hopp skirts, and doubtless more than one belle required the space of at least two if not three seats to prevent her ruffles from becoming mosed.

The prices of tickets were: dress olrcle and parquet, serenty-five cents; second tier, thirly-five cents; third tier, twanty-five chits; boxes, five dollars. In 1859 , Fobruary, the competition offered the Ihoatre by road companies playing in the Masonio Temple and Mozart Hall was great that 
Manager Mellus reduced the prices to flfty, twenty-five, and flftean centis; He was determined to have audiences in his Theatre if he had to admit the spectators free. According to the Daily Journal he even said that if free admission would not suffice, he would offer a free supper before and ball after the performance to attrect poople. Evidently Mr. Mellus was not reduced to such desperate stralts, for in the fall of 1859 , the Theatre reopened with the former boale of prices, and atters seem to have progressed mare profitably.

During the zate fifties and the early sixties there was areat fad for spoctuoles in the theatres; and it was frequently the case that the stobk companies at the theatres were ueed only for the production of these spectacles. Then stars appeared the compantes supported them. The Loulsvillo Dally Journel in Novewber 186̆8, made onjegtion to the star system on the ground that it ruined the business of the theatre. Patrons of the theatre were prone to wait until the appearance of a star to attend. the theatre, and then, when the star did cone, they would wait unt1l benofit night (Friday) to go to see him. That arrangement was profitable for the star, but made rathor poor business for the management. The paper asked for an effictent stock company wht ch could perform in plays of morit as well in in spectablos.

Thether the article in the paper had a great deal of effect or not we do not know, but in 1859 and 1860 the Theltro was pessessed of an excollent stock company Including Mr. and Mrs, John Lorton, Marcus Elmore; Sam Fyan, Kate Denin Ryan, Robert Grexson, Claude Familton, Miss E. Miteholl, and Mias Julia Jones. They playod in plays like LOVE'S SACRIFICE, THE SCHDOL FOR SCANDAI, THE FGIALE GAMBLER, AGIES DE VBRE' PHRALE PHORT, STILL FATERS RUN DEEP, THE CORSICAN BROTHERS, OOR AMRICAN COUSIN, and that play of plays, THE HIDDEN HAND. The Christwas season was the $t$ ine for spectacles, and then come THE NAIAD QUEEN, ALILDIN, and I1ke performanefo".

The Louisville Theatre continued merrily on its way with the ups and downs which every playhouse knows untll the night of Friday, October 12, 1866. 
On that night, at obut twelre o'elock the Theatro oaught fire, and in hale an hour after the first fire ara was turned in the building was conswed. The loss was estimated between fifty and sixty thousand dollars, and the building carried an insuranoe of about ten thousand dollars which reverted back to $\mathrm{Mr}$. Bates from whom George Fuller had purchased the property who had in turn transferred it to Golonel Maro Mandy, whose loss was great. The Jew ish symagogue next door to the theatre was likewise badly damaged by the fire, the origin of whioh was unknown. The Hebb sisters, who were playing an engagement at the theatre the time, lost many valuable costumes, Frank Keller, the stage manager, lost prompt books and misio which were very prseious to him, and the orchestra leader, Ernest 20eller, lost a great deal of his music. Heroto efforts were to seve the structure, but nothing could sare it.

The stock company imediatebtransferred to the Academy of Music where benefits were given for the orchestre, for the stage manager, and for others who had suffered' $10 \mathrm{~s}$ because of the fire. The company remained at the Academy of Music until the opring of 1867.

Plans were imadiately set on foot for the erection of a new theatre, and on March 25, 1867, the old theatre hed been robuilt and was ro-opened with a new otoair company headed by Barnoy Macaloy and Augusta Dargon. On the occasion of the re-openting, Miss Dergon, dressed in "spotless white and an illusion searf and jewels to correspond" (Courter-Journal - October 13, 1885) spoke a poem mitten espectally for the occesion by Mr. George $D$. Prentice, the famous journalist who at that time the editor of the Daily Journal.

In 1868 the Louisville Thentre beceme the Louisvile Opera House, and under that neme it continued to house the best attractions and stars of the day until 1873 when Macauley's Theatre was opened, and the Opera House had mun its course. In December, 1873, it was reeopened as Deagle's Varietz Theatre, and again in $1874 \mathrm{Day}$ and Hatcher tried to use 1 as variety 
houre; but suceepls seoned to have departed from it, and it wes abandoned to the use of mateury and for ocoasional concerts. Even those uses became less and less frequent, and at last the the old bullding was not in use at 211. It stood idle for several years, and then it was torn down to make way for the old Courier-Journal bullding.

Thus wach, then, for the theatres auring the civil Far. It might have been supposed that there would have been a dearth of amisements in the city during that period, but on the contrary, there was, if anything, an increase in the number and the kinds of entertainments offered. The seasons on the theatres were long. They bogan uoually near the first of September and oontinued well into June and scmetimes into July. In time of war; we wheve seen during the last war, people often sfek amusement and recreation simply for the sake of forgettingthe troubie and the misery about triem, and that may account for the presence of active theutrical life in Louisville during the Civil War period. Louisville at that time, too, was on the very border botween the North and the South, and she naturally a center of 11le, erid Since there was no cessation of theatre life in Loulevile, there was no material or tengible chinge after the war. Interest in motters of the stage had not falled, and after the wair the theatre continued on its way, with a different trend, perhaps, for the theatremes bound to feil the effects of the war, but with people all orer tho country taking the same, and even an increased, interest in the attractions which were offered.

In June, 1867, there, was opened a hall which played a prominent part in the theatrical history of Lou isville unt1l shortly after 1900 . This was old Teisiger Fall, as it was first called. The Fill was located in what was then the Her Central Market fouse and occupled the second floor of that building which stood between Falnut and Green (LIberty) Streets on Fourth, where the Kaufman-Straus department store is now (1921).

During itycareer as Teisiger Hall its stage held not few famous performers. In 1868 the comedian Sol Smlth Hanell and the Peak family appeared 
there, and in Jahuery of the sing year Finny Janaus ohek played an engagewent

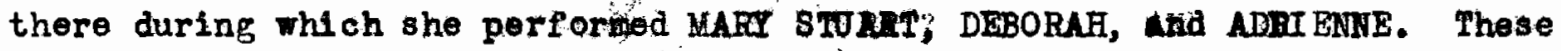
plays were performod In Germin, "but several years later Madame Janauschek had so fer mestered the Bnglish langaego as to bo ablo to perform in English. She appeared at Feisiger Hall again in Jamary, 8869, and at numerous other times when the Hil had beoome the Opera House. Ole. Bull gave several concont

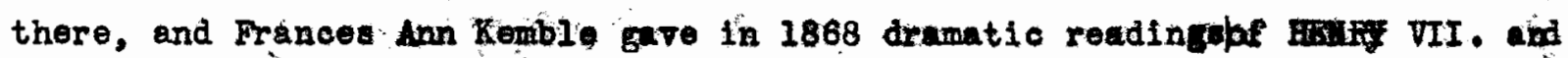
THE MEREY FIVES OF KUMSOR. Bret Harte gave his famoüs lecture, THE AROONAUTS OF ' 49 , in that theatre in April, 1873. Then Vieisiger frll was not in use for dramatic entertainments, it was being used by opera companies; minstrel troupes, ard, leter in 1ts cureer, by road companies, and by many of the combinations which sprang up during the seventies.

In 1872 Kelsiger became Pualta Library ball, for the whole building had come under the control of the library organization through funds derived from the Kentucky State Lottery. In 1874 the flall was put into good condition as theatre and contimed in use for many years. Robert McFrde in RIP VAN WINKLE, the Tony Denier Troupe, the Kellogg Opera Troupe, Mrs. Chanfrau and her varsotiles, MCKeo Rankin and Hity Blanchard, Berry Mitcholl and his company are onfy fow of the thany actors and organizations which appeared during the dareer of Publlo Library Hall.

In 1878 Library 11 became known as the Opera House, and the years when it was known by the lattor num were the most famous and rich of the varied career of Feisiger Fall. It Hed wh Macauley's in that period in offering artists and organizations of revi merit, never quite attaining the degree of excellence of elther Macauley's or the Masonic Theatres, but yot housing worthy productions and actors who in lator years bocame more famous than they were then. Wat $c$. Goodwin appeared there in 1882 in THE MAMBR FOR SLOCOM and in HOBBIES; Strakoseh and Hoses English Opere company, the Kellogg Opera company, the fumour glelan; Hermann, J. L. Sullivan in the GLADIATORS, Mr. and Mrs. Chanfrau, Madme Januas chek, Tony Denter's 
Humpty Dumpty Troupe, and in notrel troupes of the first rank all visited the Opera Horise.

The Opera House in 1884 became Harris' Mammoth Museum and Theatre, and under that name it oporated for soveral years. Harris maintained, in addition to the theatricil performances, maseum where various and sundry curiosities were exhibited from time to time. The Seven Sutherland S1sters and Mrs. Tom Thumb risited Farris' Museum in 1884. In the late eighties the theatre was known simply as Earris' Theatre, and the standard of the theatrical offering was fairly high with occasion famous organizations like the Wilbur Opera Company, Tony Denier's Troupe, or Edwin Arden performing there. But for the greater part of the time the stage was devoted to plays given by traveling companies. In geforel these were plays which hade been very poptalar but were no longer nem. Dramas 1ike ESMERALDA, THE STRAIGLERS OF PARIS, UHCLE TOM'S CABIH, DAVY CROCKETT, TEE HOOP OF GOLD, THE BANKER'S

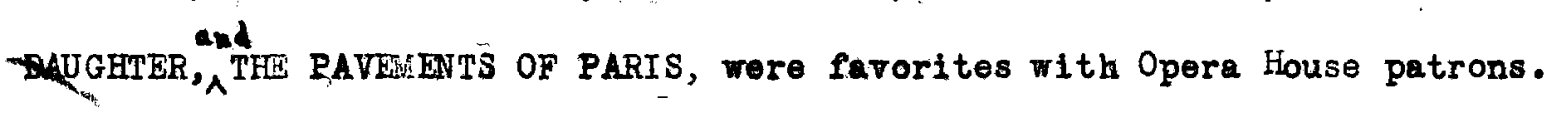
Shortly before the building passed out of existence it was known as the BIjon Theatre. The careet of Vielsiger Fall was as varied as that of Mozart Hall, and while it never housed an audience assembled to hear Jenny Lind, yet it had its illustrious moments.

of lesser theatres there were an abundance during the late seventies and the eighties. The Daris Theatre opened in December,1878, with the FROG OPERA, and for a short time tut mantained a very good standatd of offerings, the Ema Abbott Opera Company and the Jemnie Hughes Dramatic Company belng two of the best organizations which performed there. The theatre was located on Jefferson Street between Third and Fourth Streets. In 1880 it beceme known as the Standard and later was probably the Gom. There were also the Nórelty Theatre on Jefferson Street near Fourth and the Metropolitan on Third Streot between Green and Valnut, which had begun its career as the Vaudeville Theatre. When the Metropolitan burned in 1880, Whallen's Buckingham took its place as the theatre offerlng the sort of amusement to by 
found the Hetropoliten.

The buolutighw later remored to the New Grand Thpeatre whlch had once been the Mroll and was located on Jefferson Street near Second. The Kniakbodker. Theatre on Jefferson Stretetbelowe Fourth was devoted to varieties. The Grand Central Theatre was located on Third Streot between Jefferson ind Market Strpets.

Liederkranz Fil had been built in 1872 and became the Grand Theatre under: the Thallen Interests in 1884. In 1886 it became Music Hall where numerous concerts and enterteinients were given. Farly in the trentieth century Music Hall became the Fopkins. Theatre, and under that name it wes operated as a vauderille house for severäl years, although Madame Bersardt, did appear there for one engagement in dram.

No history of the theatre in Louis vilie would be complete without making some mention of the German theatrical performances of the latter part of the nineteenth century. Mozart Hall, the Masonic Temple, Liederkrant Hall, and sometimes Macauley's, all housed German theatrical companies at one thme or another. Various theatre companies from other oities such as the Stadt Theatre Company from Cincinnat1 and the New York Gormania Theatro Company gavo palys in the forelgn language. In 1881 Friederich Fuse, a great German actor Ith the New York Theatre Company, appeared at Liederkranz Fall in Otoh plays as LORBEERBAIM, IM WORZIMMER SEINER EXCELLENZ, DIE BETDEN KXIYSBERG, SIE IST WAFTSINNIG. The newspapers spoke highty of the performaneos of this actor and remarked that the support afforded by the company was better than that to be found in most of the Bnglish theatres. Other plays which were presented were DIE RAUBER, DIE JUNGFRAU VON ORLEANS, JANE EYRE ODER DIE TAISE, KAISER JOSEPI II, and among the actors were found Wolff, Forrett, Zoeller, Mttermarzer, Hunkel, Farst, and Miss Pauline Meaubert. During the early part of the twentieth century there were performances of plays given in German; bat thoy became less and less frequent as the years passed. 
theatre of thestres in houls 711 e his beon raculoy's. It 1 s there that the vast majority of the famous players have appeared, and from thetine of its founding until the present day Mecalloy's has always presented to the people of the city the best that has come its ray in theatricel entertainment. This is a notable pesord for a theatre to maintain, for it is now (1921) almost fifty years since Macauley's Theatre firat opened its doors to an audience of theafre-gowrs in Louisvilie.

It was on Ootober 13, 1873, that Barney Macauley offered his first play in the playhouse named for him. The theatre is located on fialnut street near Fourth and was built on property purchased from $W$. A. Meriwether. At that time Walnut Street wes principeliy street for residences, and the ti tre theatre was, therefore, youted in a quit part of the city where there was not a great deil of noise to disturb the performances. The aotual construstion of the bullding was begun in $3 u l y, 1873$, and Messrs. MoElpetrick and Son were the archttects. The original cost of the building was in the neighborbood of tro hundred thousand dollars, which was a great outlay of momat in those days.

The theatre was so bullt that Mr. Macauley used the upper stories of the building as a restence, and in latier years his brother, colonel rohn T. Macauley, used thepes in apartment during the winter. Colonel Macauley succeoded his brother, Barney, annager of the theatre in 1879 and retalned the managent of it practieally wht11 his death in 1916. Filliam A. Ferner was the first bestness anager.

The terial dimensions of the theatre remain the same as when it was built, but interior arrangements have changed as time has pasṣed. Tho main onst trance is twenty-five feet wide by ofxty feet long, and the fodr was covered with marble and slate. There were three ticket windows. The walls of the entrance used to be lined with colonel Necanloy's amoas gallery of theatrical portraits which is know throughout the country, but a fow years agothese

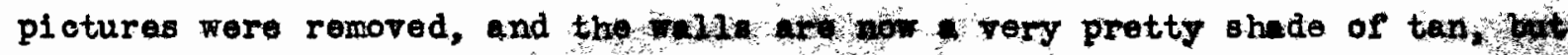




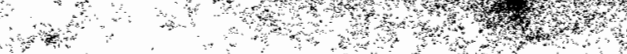

they are not nearly so thtoposting to study wa they were when the pictures of the celebrities of the yeurs gone by adorned them. These pictures were alse hung partly around the wills on the first floor.

From the footlights forward the theatre measures seventy by eighty feet. The baluster of the parquet was made of walmut, and an ornamental wainscoting four feet hightextended around the walls. The ceiling was panelled and ornamented with paintings of figures of actors and actrosses representing tragedy and comedy. The tregte fl gures wore Bdwin Booth, Charlotte Cushman, and Raohel Macailey, the ifo of Barney Macauley and a very good actress in her day. Joseph Jefferson and Lottarrepresented comedy.

There are. four prosconium boxes, two upper and two lower. The lower boxes were ornumented one with bust of shakespeare, and the other with a bust of Mozart. The seating capacity of the theatre is botween fourtoen and fifteen hundred, but the theatre had been knom to hold many more than that number on occasion. There are balcony and allery in addition to the ground Ploor. The balcony has always been a very comfortable place in which to sit, but it is only within the last theee or four gears that there have been seata in the gallery. Previous to that time; the spectators sat on the wooden steps: which formed the only seats in the "roost". It that time the gallery seats were not reserved, and countlesay mum beings could be squeezed on the steps who could not be nocomolated in the legless ohnirs whito are now fastened to the steps and form the seats thiwhet has been the heaven of more than one ardent Louistille devotee of the dram who had more love for the art than he had pence in his purse.

The stage of the theatre is forty feet deop with proscenium opening thirty-six feet in the clear by thirty-seven feet high. At the time of its opening there were five sets of grooves for scenery on the stage, and fourteen sets of coenery. There nine "traps" on the stage, and the theatre was fitted with two curtains. $O_{n}$ was of rod balze and was used until the performances began, the other represented sulas Iundeape painted by the artiat Mald ho 
who was a the oepto artlot for the thetre. In the scene ras otion a lake in the right foroground th molintains in the right background. On the left stood a cottage on the bald bf the lako. It was said that the scene was the representation of an aptial lendscape whioh tho artist had found anring a visit to Switserland.

The footlights at Macemley's were very remarkable, for "they were made after a peculiar patent and could be changed to red, green, and white simply by the use of a valve on the etage". In 1873 those footlights were very fine, indeed.

The theatre had twelve dressing rooms under the stage, and on the whole was fitted up to be ane of the most comfortable and most pleasing theatres of its da y. The acousties of Macauleyds have elways been one of its strongest featuges, and even in 1873 the ventilition of the theatre was well attended to. On October 13, 1873, then, cauley's Theatro opened with the play called EXPRERES. Barney Macauley made an address in which he reviewed briefly the story of the bullding of the theatre and expressed his desire to make the theatre a really worthwhile playhouse in Loulsellle. sfter his speech the curtain rose, and Marte Bates in the character of Lady Crosby in EXTREMES spoke the firtet lines of any play that was ever given at the theatre. It is interesting to know that Marle Bates is still active on the Amorican atage, and that, she appeared at Macauley's during last season (1920-21) as the minister's wife wth David Farpleld in THE RETURN OF PEPER GRIMA. Mario Bates is to-day one of the most experienced actresses on the stage, and there is scarcely one who 18 her equal in the portrayal of the oburacters of eld women. She has for many yeare past been playing with Mr. Fiarfield in his various productions under the direction of David Belasco.

Barngy Macauley had renlised the nedd of the clty for a new theatre, for the old Opera House (es 1tras called at that time) was declining in prestige and efficienoy, and he met that need far better than ho or the people attending that openige realizod proowiey was an actor who had 
been for eoveral years asoctated ith the theatrical interest of Louis v1 110 . He was born on September 19, 1837, in Hew York. Hil debut was made on the stage of Hiblo's Garden In New York City in support of Matilda Heron. He married an actress, Miss Ehehel Johnson, who became more famous as Rachel Macauley. Hacaley first appeared in Louisville as the leading man in the stock company at the Louisville Theatre during the season of 1861. He became a great ravorite in the alty; and ho was alvays highly praisod and oxcoedingly popular. He headed the stock compent again in the seasons of 1862 and 1863. In 1864 he played an engagement at Woods" Theatre and closed the season for that theatro in June. In May, and agein in September, 1865, ho appeared at the Loulsville Theatre as star in such plays as RICHELIEU, RICHARD III, MACBETH, THE ROBBERS, SATNT ROSE OF LIMA, thi MARBLE HRART. In 1866 ho played two engagements at the Theatry during the last one pleying with Miss Rechel Johnson in such plays as IADY AUDLEY'S SECRET, and the highly popular EAST LYNIE. Pretlous to the opening of his own thotre Mr. Macauley, during the season of 1872-1873, was the Hanager of Keisiger. Hall. When Macauley's came under the management of Colonel John T. Hecauloy, Barnoy Macauley and his wife mat on the road again as actors. Together they played at the Masonic Temple in 1882, 1883, and 1884. Mr. Waculoy in his later yoars was particulariy famous for his duracterization of Uncle Ban'l in the MESSENGER FROI

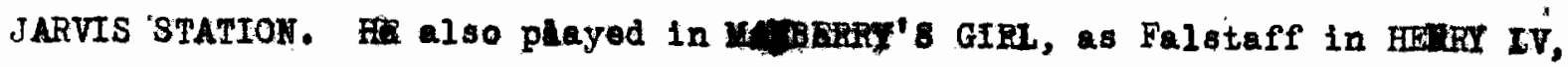
and in THE JERSEY MAN.

Mrs. Rachel Macauley was the first stax to play in hor husband's thatre, and some of the plays of that first engagement in October, 1873, vere FHOK-FROU, LADY AJDLEY'S SECRET, THE EICHBACK, LUCRETIA BORGIA, and SURE. Iuring the years that followed Mrs. Macaliey was frequently seen at the theatre, and her best liked characters wore probably those of Madane Vine and Lady Isobel in EAST LYMNE. Likemise she played in Sardou's SERAPHINE, in JANE EYRE, THE MOTHERSS SECRET, and THE SEA OF ICE. She appeared with her musband when he played at the Mesonfe Templo in the axy eighties, and aho 



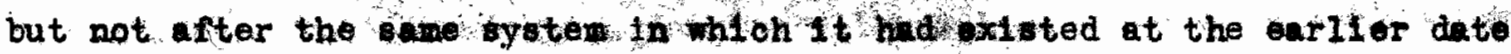
when the star alone traveled ind depended upen the theatre to furnish the supporting company.

When it comes time to speak of the players tho appeared in Lou isville, the chronicler of the thectre herdry knoirs where to begin and where to end." The players were so nuwerons, and way of them re vory famous, and some who frere not femous seem to have been very well liked and almost as popular es the most 11lustrians of the profession. :There are some who appeered perhaps once or twice and then sank into the oblivion of forgotten things; thero are others who appoared agaln and egain, year after year, in the same produttions, and crowds flocked to see them. Some of the actors seem to be the links between this period and the one preplous, and others are the lint between this and the fallowing period, and some belong entirely to this period alone.

One of the links with the preflous period was Julia Dean, who, after her marriag with Dr. Haynerin 1855 was known as Julie Dean Hayno. As has been sald before, Louisville loved Julie Dean end never, forgbt that Miss Dean had practically made her start in the ofty, et leabs the people of Loulevillo l1ked to thinkso. But public is sonewhat flckle, and in 1859 the Daily Journal. found cuse to remind the poople of the city that they should not neglect to welcome an actress who cume in the full power and glory of a realiy fine art whom they had petted and polied as a novice. In 1856 Mtss Dean played for the first time in Louls ille GRISELDIS, a play written by Him and of which she possessed the only copy extatt. GRLSELDIS was always an important chiraoter in her repertofre curing the remainder of her years on the stage. Julia Bean's engagements In Lou'isvilie uavally lasted two woeks or thré, , and many of her characters whe played over and over again, notably Julia in THE HUNC HBACK. During the engagement in 1866, on January 25, her benegit. night, Miss Dean performed the play called MAP OF MANUA which she had written herself. On that ocension she spoke an epilogue written by the poet $F_{.}$. 


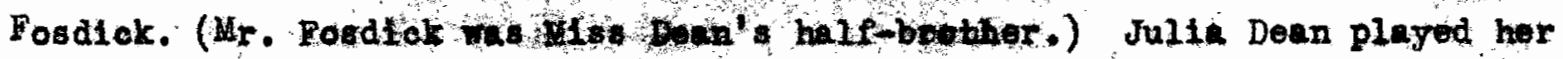
last engagoment at the Louloxille Thentro firovember 27 to December $7,1867$. The plays during that time included THE FUHCEBACK, LEAF THE FORSAKEH, SHE HOULD AND SHE HOULDN' $\mathrm{T}$, and THE FOMAN IN VHIT. In March, 1868, Julia Dean died. Edwin Foorest appenred in Louisville for the last time in December, 1869, per rming in VIRGINIUS, OTHELLO, RICHARD III, and KING LEAR.

Ms. G. H. GLlbert wis mother actress whom Lou isville knew during the earlier period. It knew her first as a dancer with her husband at the Louisville Theatre where they were employed. In 1857 Mrs. Gilbert was a member of the stock company at the Theatre, and she wes evidently playlng a line of character parts that time, for in 1858 she played the lurse to MisB Avonia Jones' Juliet, and ras recognized as supreme in her characterization of that part. The Gilberts during the years of their residence in Loulsville lived on thewest aide of Fourth Street between Filnut and Chestnut, and there, in addition to his work at the the tre, Mr. Gilbert gave dancing lessons. In 1859 the Gilberts joined the Koods' Theatre company in Cinolnnati, and Louisville regognized its loss, and was sorry to lose them. Mrs. Gilbert until her death in 1904 was perhape the most fumous delineator of old women on tho American stage, and Loulsytllo may be prond of the fact that it knew her at the very outset of her career.

Other actors who had been famous in earlier years were Mr. and Mrs. James $V$. Hallack who were known for thelr characterizations in THE IEOW MASR, MACBETH, THE TINTER'S TALE, KINO OF THE COMONS, OLIVER TWIST, ST. MARC, and JULIUS CAESAR? There were the Fallers (Mr. and Mrs.) who performed with great applause in THE DUCHESS OF MALEI, GUY MANERING, THE STRANGER, FMLET (Mrs. Waller as Hamlet), and OTHELLOS (Mr. Waller as Othello and Mrs. Waller as Iago.) Agnes Robertion, the Fairy Star, who made her first appearance in Louistille with her husband Dion Bouplcault, an actor who is more famous for the mumerous plays he wrote than for his acting, is another link between the two periods. The Festern S1sters, Mr. and Mrs. F. J. Florence, Mrs. 


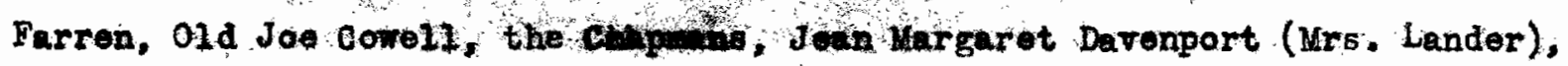
Mrs. Mary Provost Adave, Amptte Ince; Mis K Kmberly, Mrs and Mrs. Barnoy Williams, Mr. and Mrs. Chanfray, John Collins, Nenfle the tragedian, Couldock the list might be extended to great length - Louisville knew in previous times and received heartily whenever they appecred. The last mention we find of the once famous Mrs. Alexander Drake is on the occuston of a beneflt given in her honor by members of the Hokens club of Leuisvile in 1874 at the old Louisvil1e 'Opera House which had seeri man of Mrs. Drake's triumphs of her later years. Two prominenteactors of the period who may be spoken of together because of thelr great friendship are Edwin Adams and John Mćcullough. Eadh of them enfoyed a wide popularity, athough Adams was known in Louis ville several yoars before MoCullagh appeared. Bdwin Adams played first at Voods' Theatre for two woeks in December, 18̈63, in HANLET, THE HERETIC, HOMBO AMD JULIET, and DEAD HEART. Hardly season passed after that when Mr. Adams was not a great attraction ether at Foods', at the Louisville Opera House, or at Macauloy's. Some of the plays in which he was successful in Louisilile wer MARBLE FEART, WILD OATS, THE ROBBERS, THE TICKET OR LEAVE MAN, and ENOCH ARUEN. ELOCH ARDEH was one of the last palys in which Edwin Adems appeared in the city, that was in 1876. He never came to Louisville again. vocullough was particularly famous for his portrayals in RICHELIEU, ; MACBETH, OTHELL,; FICHARD III, and most of all in THE GLADIATOR. It ms duri nf MeCullough's appearance in Loui syille in September, 1875, that he metpendeuraged Mary Anderson. MoCullough wa the best representative of Spartacus tin the GLADIazOR since Forrest had played in the part, and his rendididonof the charactergres very well liked in Louterille.

Matilda Heron, the ectress who wa particulerly.known for her translation of the play CAMILLE and her impersonation of that unfortunate lady, mas seen in Louis ville frequently betwoen 1855 and 1866 . CAILLE was always the anstay of her ropertoire, but in addition she presented THE BELLE OF TEE SEASOY,

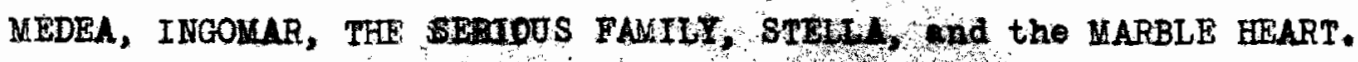


Laura Keene, the fonove mangeress and actress, and her company appeared for three weoks at the Louistille Theatre in Hovember, 1863, presenting suoh plays as SHE STOOPS TO GONOUER, UHEQUAL MATCH, THE SCHOOL FOR SCANDAL, OGARITA, THE ELVES, and OUR AERICAN COUSIN, She played two engagaments at Foods' Theatre in 1865. Mr. and Mrs. Chaties John Kean (Mrs. Kean is better known as Elien Tree) visited Louis 1110 in 1865 and 1866 performing once at woods's and once at the theatre. They presented THE MERCHANT OF VENICE, HAMLET, RIC HARDIII, LOUIS XI' WUCH ADO ABOUT NOTHING, And MACBETH.

Another Koone who was popular in Loui oville was Thomas Keene, the tragedian, who appeared at nurerous times during the elghties at Macauley's. He performed the recular roportoire for tragediens, and he mast have been popular in the city, for scarcely a season passed that he was not engaged for a time at the theatre.

James H. Frckett, who had been famous for many years for his Falstaff, continued to be great fuvorite in Louisville until his last appearance at the Louisville Opera House in 1868. Hackett besides his other charaoters played RIP VAN WIHKIF, and he was very god in the part particularly at certain points, but Loulsville preferred Jefferson's Rip, and oritic makes a remark to the offect that Hackett played RIP $V_{a n}$ Winklo as well as Jeffersen might have played Falstaff.

James E. Murdoch appeared in Loulsville year after year in such pleys as HAMLET, THE DRAMATIST, RICHELIEU, THE IADY OF LYONS, MACBETH, and DESOTO. The latter play Murdoch first brought to Louisvillo in 1855, and it was a part of his repertoire for yoars. Murdoch made his last appearance in Louisville in the early seventies as a dramatic reader the Masonio Temple and at Teisiger Hall.

The name of Mitchell was a very fanliar one to loulsilile, for there were two actresses of that name who vere especial favorites. One was Mary Mitchell who enjoyed great popularity in THE HIDDEN HAND, CAMILLE? 
THE VIFE'S SECRET, LIFE IN THE STREETS, MAOD'S PERIEI LONDON ASSURAHCE, SATAN IN PARIS, OUR MUTUAL FRIEID, and ROMEO AND JULIET. MiBB Mitchell appesred at Wogds', at the Loulsvilie Theatre, and at Macauley's.

The more farcus of the two ladies of the name Mitchell was Maggie Mitchell who delighted audiences during the fifties, sixties, seventies, and eighties. Hor most fanous characterization was that of Fanchon in FANCHON THE CRICKET, but anong other plays in which she appeared were LITTLE BAREFOOT, LITTIE TREASURE, MILIY, WILD IRISH GIRL, WANDERING BOYS, JANE BYRE, LORLE or the Artist's Dream, WABGIE THE WDGET, and the PEARL OF SAVOY. Another actress in somewhat the ame category as Maggie Mitchell was Lotta Crabtree, kngwn simply as Lotta. Lotta was more famous than

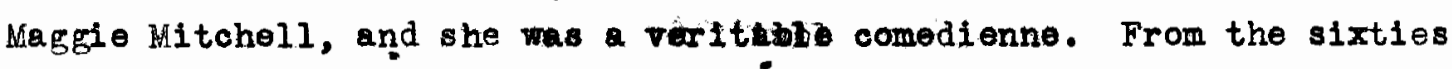
through the elghties sho was always grested by onormous audiences, and the name Lotta meant money in the purses of the theatre menagers. 2IP, BOB, and MUSETTE were favorites among her plays, and besides she frequently played in LITTLE NELL, TFE LITTLE DETECTIVE, HEART'S EASE, and IA CIGALE.

During the fifites and the sixties E. L. Darenport visited Louisvilie many times. In 1864 he was assodeted with Mr. and Mrs. Wallack, and they gave notable performances in THE IRON MASK, HAMLET, RICHELIEd, ST? MARC, and the LANCERS.

Miss Fanny Davenport appeared in Loulsville at the Theatre first in 1867, but her most frequent visits vere wade during the vighties whenswine performed sowptins at the Masonic Temple, and sometimes at yacauley's. A play called PIQUE written by Axgustin Daly was onotof the most popular of her vehicles, but she 10 to played in CAMILLE; BdTH THE TRANP, A PRINCESS OF BAGDAD, THE SCHOOL FOH SOANDAL, AS YOU LIKE IT, and LONDON ASSURANCE. In 1885 and 1886 she appeared at the Kasonic Temple in FEDORA, and in the latter year her leadidy man we Mr. Mobert B. Mantell. Mr. Mant in the same year appeared as a star under tho magement of Augustus Pitou in

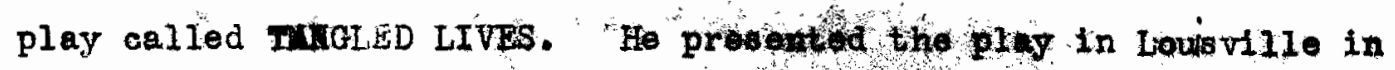


November, 1886. In 1882 one of the louldr/11e pepers ocimented upon the cact that Miss Davenport arrived in Loufaville in her special car; so one can imagine that she was ary important lady, indeed.

While speaking of those who bore the wame of Davenport, one should not negleot to mention Jean Margaret Devenport (Mrs. Lander) who impreesed her Loulsville audiences vastly and hold thow opell bound with her performanos: In 1858 of MEDY? WONA LI8A, THE MAID OF MARTENDORPT, MASKS AND FACES, and CHARLOTTE CORDAY. In the oixties Mrs. Lander presented particuariry plays such the GUEEY OF ENGLAND, and MARY STUXAT.

Prank Mayo who prosented and became so intimately identified ith the character of Dery Crockett in the play of the samen nime must not be forgotten. Ho appeared in ather plays; among them HAMLT, MACBETH, RICHARD III, THE 8TREETS OF NEY TORS, and HORDECK, but the memory of his DAVI CROCKETT hat outlived all others.

Another man who bocane Identified with one particular character at about thaoskne tame or Dberlyethe same time when Mayo was playing Crockett was James O'Meil. O'Hell played Edmand Dantes in the COUNT OF MONTE CRISTO for years, and the name of the character and of the man who played it were a.1mays ssociated. TH COINT OF MONTS CRISTO appeared at Macauley's many times during the ofght1es; the first tine of Its presentation by 0 ivell was in 1884.

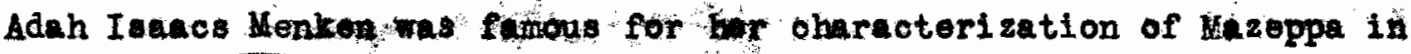
MACEPP which she first presented in Louforille in 1863 . Previous to that appearance, however, the actress had gained wide populartty in the city in plays such as THE FREICA SPY, IOLA WONTEZ, and GREAT EXPECTATIONS. An Interesting Item in regard to her appenarice In March and April, 1862, is the

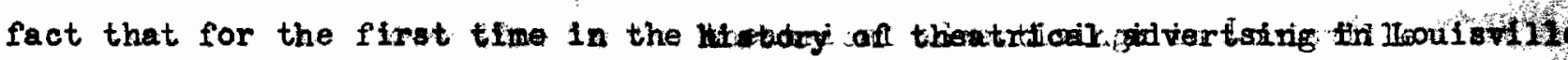
Fepers a picture of the aetress appeared in confunction with the announce- . ment of the play bili. This was doubtiess accina $\therefore$ : to the fact that urs. Menken was very popular at that time. matorios of the thentre record the 
fact that Mre. Henken was the ftrot actress in the character of Mazeppa to permit herself to be tied to the back of th. Wild horse whose dash around the atage was the thrilling fentwe of the play.

The play LOLA MOITEZ was based upon the adventures of the real Lole Montez who appeared in Loulevilie in 1857 and in 1860 . She was advertisad as the countess of Landsfelt, and she appeared in a play called LOLA MOHTEZ IN BAVARIA, purporting to irecolmet, her expertences at the court there. She alvo appeared in THE FOLLIES OF A NIEHT, THE CABIN BOY, a comedy called ANTOHY AND CLEOPATRA, and the SCHOOL FOR SCANDAL. Towerd the end of the second week of her engagement at the Loulsvi110 Theatre-in April, 1857, the lady, who mist have been very temperamentel, had a quarrel with the maneger on the otage in the very midst of the performance in full view of the watence. Then matters failed to be settled s she desired, she walked from the stage refusing to pley, and the curtain had to be rung down

An event which would be of importancer only in a history of the theatre in Louisville was the appearance In September and October, 1859, of the Gougenheim Sisters (Joey and Adelaide) at the Louisville Theatre: These. young ladies were immensely populin - flowin from the fact that they performed to paked houees in the theatre for firo wooks. They played such plajs as UUC ADO ABOUT FOTHING, THE RIVALS, MTD OF MUNSTER, THE UNEQUAL MANCH, and DOT. But the piecede regietence of the engagement was the performance of the HIDDEN FAND, the play adapted from the tory of the same name in the York Ledger. The adapter was Robert Jones, the prompter at the Louistillo Theatre. The reason for mentionthg this incident is the fact that in foar night performances of the HEDEF HAND the Theatre took in over tmo thoueand dollars, which was no $8 \mathrm{mall}$ sum in those days. The play ran steadily for two weoks, and it wo repeated frequently afterward by many different actroseoto There is no record of the Gougenheim' having eppenred at the theatre in Louis 1110 after the first engagement except the return of Hiss Joey tat 


\section{Saleen (or Suleenh) bottor was an actress who began her career}

on the stage in Louistille at about the same time as Mary Anderson. She appeared froquently in hor home city during the eighties in such plays as ISABELLA OR THE FATAL MIRRIAGE, THE VIFE, and the STRAHGLERS OF PARIS.

One of the most excellent comedidns whom the American stage hes known was John E. Owens, and during the sixties and the seventi es he was a frequent performer in Loui ovi12e: . He played the Loulo ville Thoatre before it burned and again after it was rebulit and was called the Opera House; he playdd at Foods' and at Hacaloy'. His most famous elaracterization was that of solon Shingle in THE PEOPLE'S LATIER, but he was also very fine in the TICKET OF LEAVE MAN, PADL PFY, THE FEIR A9 LAt, MARRIRD LIFE, FORAT WIMKS, and OTR BOYS. John Drew, Sr.; the father of the John Drew of later years, Houisille saw and enjoyod in his Imperoonations of Irish chmracters in 1856 and 1858 in plays like THE IRISH MBASSADOR, HAHDT ANDY, ST. PATRICE'S EVE, THE KNIGHT OF ARVA, and RORY O'MORE.

Frank Drew', enother expellent comedian and actor, was seen occasionally during the fifties and sixties in such pleys as HELPING HANDS, LIFE OF AN ACTRESS, THE PEOPLE'S CANDIDATE, and OOR AMERICART COUSIR.

In naning comedians one mast not leave out the name of John $T$; Raymond who delighted thousands during the seventies and of ghties with RISKS, THE WO* MAN HATER; COLONEL MULBERRY SELLERS, and the MAGISTRATE.

Al the performers at the Lowisrilie theatre cannot be mentioned. Most of the lesser playera are forgotten, and yet oach one played his or hor part in the history of the stage in Louigrille. Fo have endearoured to mentione those who seemed to have been best received and most popular with Louts villo audiences, and quite naturally may of them are those well known in the history of the American stage. The ones remainting to be spoken of are those whose names ire, even to this day, almost household words, while most of those mentioned before are known generally only to those who take an especiea 
pleygoers who dellght in renembering the glorious days of years gone by. There are Charlotte Thompson, Olive Logan, Bliza Logan, Ently Thorne, Fillian J. Scenllan, Eduln Thoone, J. L. Toolo, Marcus Elmore, J. K. Bmet, with hts amusing Fritz characterizations, Mrs. Soott-siddons, Bary Sullivan, Sallie St. Cialr, Dora Shaw, Cenerieve Rogers; Kate Bateman, Susan Denin, Iucy Rushtion, MoKeo Rank1n; IItty Bglnohard, Cecile Rush, Caroline and Peter Richings, Effle Elloler who produced in 1885 THE OLD KENTUCKY HOME In Louisville, wark Smith and his compry, and literally scores of others to Whom it seems an injustioe not to montion more than their namos.

The mention of Mark sinth recallo anincident related by Mr. Magustus Pitou in MASTEFSOF THE SHOW (Page 85.). Xr. PItou, who was a member of Mr; Smith's company telis of the indident thus, "Mark Smith clained that the actor's art was above ell others. Ho would often express his pride in being an actor: He endeavoured at all times to be dignified, but he was at times a trifle pompour. I was standing in frov of the old Louisville Hatel one day with him and a friend of his when a gentleman apposcahed and was introduced to us. "Oh, Mark Smithl I am delighted to meet you, sir. I had the pleasure of seeing your troupe lest night at the theatre."

"Mr. Snith at on assumed his most dignifted manner and sa1d; 'fot uy troupe, sir, bat company. We rare not itinerant aorobats nor performing: monkeys'.

"The gentlemen raised his the and sald: 'I beg your pardon, sir, and I think you. I shall observe the dibknction in future.'

"We learned later that that wume gentlemen hed killed one man and wounded another on the 'fland of honor'. Fortunately the eplsode terminated in our adjourning to the hotel and imbibing several mint juleps."

It was this same company of Lerk Smith who were deprived of an engagement at McZivker's in Cht engo by the freat fire there in oatober, 1871, and who, being unable to meturn to loutorille where thoy had played their most successful engagement, porformed t the Opera Hatse in New Mbany in the hope 
that some of the touidoilie people would come over the river to see them. The New Albany Opera House wis at that time lookted over a meat market, and thim trials in that place of amsement were many, not the least of them being the effort required to persuad the old colored man who lowered the curtain to perform that operation at the proper time.

There is a long list of great forelgn actors and actresses who appeared in Loufsville, but most prominent among them gre janauschek, Ristori, Seebach, Ponisi, Fechter, Bephyrdt, Salvini, ánd Mrs. Langtry.

Madame Janauschek and Madame Ponisi, an English actress, were long poominent figures on the smerican stage, but the others came and reat, making only oocasional vistt to this country.

Janauschek at first played in German, but in later years she used the Englioh languege, presenting such plays as MARIE ANTOINETTE, ZILIAH, MOTHER AND SOH, and GUY MANNERING. Sho was always a powerful actress, and Louisville always receited her well. Madamo Ponist was in Louisville in 1864, presenting among othor plays MACBETH AND THE STRAHGER. Later she beome momber of Fialletk's stookircompany in Hea York.

Adelaid Ristorl was et the Masonio Hall in MEDRA, MARY STJART, ELIZABETH, QUEBN OF BNGLADD, and MACBETH. In 1867. In Hovember, 1884, she performed at Macaley's in Bnglish presenting ELI ZABETH QUEEN OF ENGLAND, MARY STUMT, and MARIE ANTOINBTTE.

Mario Seobsch acted at Tolstgor Ell in December, 1870, in JANE ETRE, and in FAUST, Charles Fechter, the Halish tragedian, paid Louditile 7isit in December, 1874, pleylng at Maceuley's. Miss Lizzie Price was his leading woman, and they presented RUY BLAS, THE INDY OF LYOHS, HAMLET, NO THOROFARE, and DOH CESAR DE BAZAN. Tomaso Salvint, the great Italian, appeared first in Louisvillo in Iamary, 1874, in HUKET and BLIZABETH OF. ENGLAND and acted at Library Hell. At that time his supporting company with the exception of Signora Piumonti es Ophells was not up to the standard one

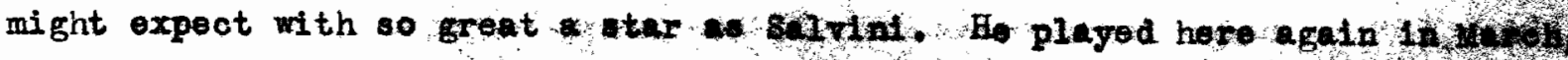



for almost ton yeare - the Staurt Robson end WIIIan H. Crano combinatlons. Thoy appeared in OUR BMCHELORS, and during the decade which followed Louisvilio saw them as the Tro Dromios in THE COMEDY OF ERRORS, in THELFTH NIGHT, in SHARPS ARD FLATS, and in SHE STOOPS TO CONQUER. In 1889 Filliam H. Crano appeared alone in a play calied ON PROBATION mritten by Brander Matthews and Georgo H. Jessop, and in THE SENATOR, THE BALLOON, and PAPA PERRICHON. The Madison Square Theatre company in 1884 presented a remarkable cast in HAZEL KIRKE. Some of the mombers of that company rere $c$. $W$. Couldock, Innie Russell, J. G. Gramm, Mrs, E. L. Davenport, De Tolf Hopper, Ade Gilman, T. H. Crompton, and Cecilie Rush.

Richard Mansfield, one of the finest actors on the merican sta during the nineties and the early years of the twentieth century appeared here in 1883 in A PARISIAN ROMANCE, and in 1886 and again in 1887 in PRTNCE KARL, the latter part which was always considered one of his bet characterizations. In 1884 Tilliam Gillette appeared in THE SECRETARY and in THE YOUNG MRS. WINTHROP. Nat C. Goodurin first appeared in Louisvillo tith Rl co and Goodrin! E EVANGELINE Musicel Extravaganza Combinationa in Marọ, 1897. Ho wes almost an annual performer at the theatres after that time, several times in association with Blisa Fenthers by in FEATHERSY'S FROLIQUES and in Feather sby and Goodatn. In 1882 Mr. and Mrs. Coodwin appeered at the Opera House (Library 11) In THE MIMBER FRO SLOCOM, and other plays which Goodwin prosented on subsequent risits were MAY BLOSSOY, HOBBIBS, MONTE CRISTO, CONFUSIOH, THE SKATING RINK, and IN A GOLD MINE.

Now we come to speak of the greatest plavers of the perlod, those whose names have gone down in history as the Pinest of their dey: Joseph Jefferson, E. A. Sothern, Adelaide Netlson, Helena Hodjeske, Lawience Barrett, Edvin Booth, and dearest of all to Louisvilio, Mary Anderson.

E. A. Sothern first came to Louisolule in 1860 and played an engagement at the Louisville Theatre from June 4 until June 16, appearing in the ROMANCE OF A POOR YOUNG MN, and in that most famous of all his characters and 
his best, Lord Dundreary in ovR MHRtoky coosIN. In 1872 he appeared in OUR AMERICAN COUSAAG again, but during a part of that engagement Mr. Sothern was 111 and ras only able to act the last fow days of his time. In 1876 in

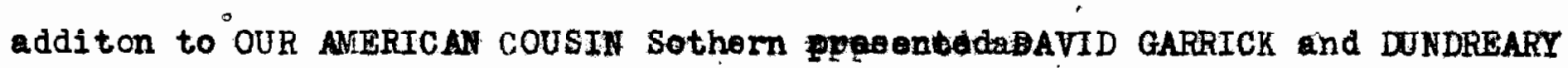
IN A HORNET'S NEST. In 1876 he had with him an espocial supporting company made up of Miss Linda Dietz, Miss E. Storis, and J. H. Barnett. There is no doubt that after Mr. Sothern's first appearance many of the young men of Louisville cultivated the etyle of the Dundreary whiskers which the actor wore as patt of his me-up, for the men of Louisville vere not materially different from other men, and Dundreary whickers were the last word in style. Lou isville flrst saw Joseph Jefferson's RIP VAN WIKLE on Maroh 23, 1868. The fame of the actor had predoded him, and over afterward whonever Joe Jefferson appeared in Louisville; it was great event. In 1869 Jefferson played an engagement from nobraty 3 to Fobrany 13 at the Theatre, and those days were spoken of as the most brilliant theatrical engagement which Louis ville had over seen. Bosides RIP VAN KIMKLE, the actor played in LEVD ME: FIVE SEILIINGS, TEE SPIT FIRE, and A REGULAR FIX. The play of RIP VAN TIN,

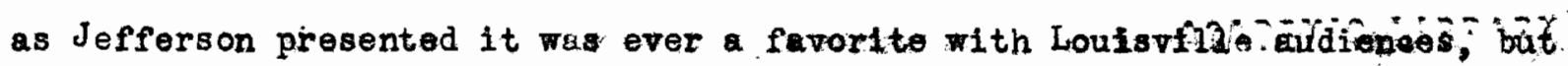
the performence of the RIYALS at Macauley's in December, "1860," must heve" been a rare tranty Jeffermon played Bob Aores with Mrs. John Drew as Mrs. Maleprop thduaurice Barrymore as Ceptain Abeolute. Other plays which tho splendid actor presented before theatre tadiences in Loulsville during tho olghtios were THE PODR GENTLEMAN, THE, CRICKET ON THE HEARTH, and THE LIGHTS O' LONDON.

The eity almays loved Joe Jefferson, and his appearances were events in the lives of the citizens, who found the man himself as kindly and as lorable as his acting was fine.

Adelaide Nelloon died in 1880, but Leik ville had seen her in 1874 in two of her best charactertzations, Jullet and Bentrice in HUCH $\triangle D O A B O U$ ? NOTHING, and remembered hex for the rowaty of those performanoes. 
Helent ${ }^{\text {mal }}$ Polish actress, and she had already galned feme in her own land before she came to America. Her maiden name was Helena Opid, but when she was very young she married a man named Gustave S. Modrzejemski, and it was this namo that was shortened at the suggestion of John MoCullough Then Madame Modjeska first actod in Amertea. Hor socond husband was Pbitth patrlot anmed Charies Bozente Chleponski, Known Bozenta in America, whom: she married after the death of Modrzejersid. Sho and Bozenta came to Americe and settled in Califoonie in 1876. There they undertook to manage a chicken farm, but the undertaking ras not sucoessful, and in 1877 Modjeska, with a little knowledge of English, resumed her acting, beginning at the California Theatre whose director John Mochllough. Thts puragraph about Modjeska's personel history is given because Louisville first sen her in April, 1878, when she was at the very beginning of hor successful career on the Umican stege. Upon that first visit har English was naturally very broken, the people thought her not very beautiful but exceedingly attractive, and her CAMrILE was "Imenes" Besides CAMILLE during that first engagement sho appeared in ROMEO AND JULIET, and ADRIEMNE LECOUVREUR.

In 1879 she appeared at tho Opera House (Library Hell) in CMILLE, a new verston of BAST LYINE, ROLEO AND JULIET, and FROU-FBOO 1883 sar her in CAMILIE Lgatm, in AS YOU IJKE IT, ODETTE, and THLFIH NIGHT, thoughout the elduties Modjeske might alwayo foll oure of a warm wolcme in Louisville, but she found that in almost every eity that she visited, for she was one of the few really great actresses of the 1 half of the nineteenth oentury. Other plays than those al ready montioned in which she appeared were MABY STHART, PRIMCE ZILAH; and THE CFOUAN, One interesting event of the ongagement of 1883 occurred on December 7. Wh that night at Macauley's Mod-

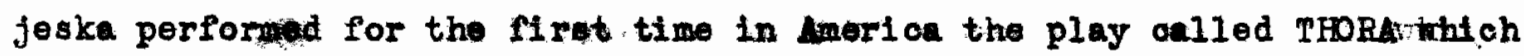
was the anme used instead of the one Ibsen hid given it, THE DOLL'S HOUSE. Thus Modjeska gave to Louldille the duttrotion of seoing the first pre- 
the following morning remaried that fuedjeske wae the performance", and in Its indifference to the play Louisville audienoes were not unusual, for the Doll's HOUSE has neter been widely popular in America.

Yodjeskn's acting 11 fe extended wil into the next period, but durthe elghtles he was in the prime of her parert and it is as the great actress of that time that she deserted most to be remembered.

In 1879 Clara Morris, onother of the famous actresses of the day, appeared at the Opere House (Library Fall) for anwenglgement of a week in April. Miss Morris gained wide fume on the atage as representative of. omotional roles, and whilo in was not as grot an actress as Modjeska or Adelaide Neilson, yet her aoting ade great impression, and ho was inmensely popular.' During the first engagement in Loulowille she appeared in ENOHH ARDEN, L'ARTICLE 47, CAMILLR, ind MISS MULTON. Of her performence in tho play uISS MULTON one pe the papers said that "nothing in the annals of the theatre in this city can be compared ith the effects produced by her acting in UISS MULTON" (Gourier-Journal - April, 1879.) During her engagoment at Macauley'a in 1886 sho appeared gain in MISS MULTHN, L'ARTICLE 47, and in adition in Alrxs.

Two great names whioh are frequëntly associated in Louls il 110 minds, because of thelr two jolnt appearances at the duiditorium at Fourth and Hill Streete, are those of Edwin Booth and Lewrenoe Barrett. When the two wotor. appeared et the Auditorium in 1889 both were almost at the ends of their areers and of their $11 \mathrm{res}$, "and both had appeared in Louls ville as a sar. alone on my previous occasions.

Barrett appeared first in Louisville from September 12 to October 1 , 1864, at the old Loulowilze Theatres playing in plays 1ike ROSEDALE, LADY OF. LYONS, and DREAMS OF DELUSION. In 1865 ho played at Toods', in 1871 at the Opera House, and after 1873 at Meoung $y^{\prime}$, Barrett was very excellent

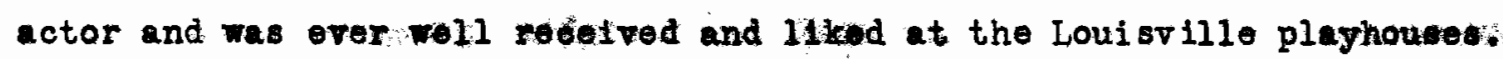

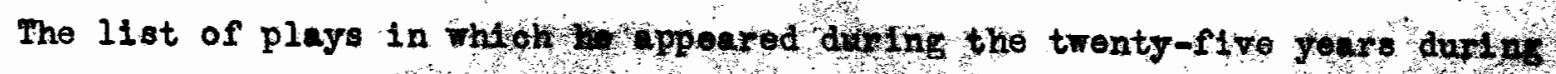


whioh he wes wore or lose frequent visitor to Louidville is a long one, but the names of few of his plays are interesting to know; Besides the dnemas already mentioned Barrett played in THF DUKE'S MOTTO, OTHELLO, RICHARD III, SARATOGA, JULIUS CAESAR (at first as Antony, leter as Cassius), RICHELIEU, HANLET, THE HERCHANT OF VHICE, MARBIS HEART, HAREBELIF, DAVID GARRICK, IH* CONSTANT, MONEY, THE HONDER, TORICE'S LOVE, FRANESCA DE RIMIII, THE KING'S PLEASURE, and the last play in which Lamrence Barrott appeared 28 atar alone, RIENZI. He gave the last named play in April, 1887.

Fdwin Booth is conidered by most critics to be the greatest actor the American stage has producod, and by many persons his representation of Femlet is consfiered the best that the Bnglioh stage of the nineteenth bentury, if not of any contury, has known. Booth was the son of the actor, Juniue Brutus Booth, and with the inisincts wich he inhorited fioh his father, he ma impelyed to his work on the atage. He once wrote to his daughter, "I had rather be an obscure farmer, a hayseed from Wayback, or a cabinitmaker, as my father advised, than the most distinguished man on earth. But nature cast me for the part she found mo best fitted for, and I have had to play it and must play it bill thoscurtain fal1s." (Quoted by Lyman Abbott in The outlook - Apr11 20, 1921.) Booth Ioved his father passionately, and one of the freat blows of his life ceme when he we far out in the west and could not reach home when hls father died. Another person whom Booth loved devotedly was his first wife, Mary Devlin, and after har death it was the love of her that held him true to the highest Ideals in art and in life. Booth's reply to the clergyman who wrote to ask if he might not be admitted to the theatre through a side or rear door so that none of his partshioners might see him is famous, and is also illustrative of the character of the man who made its." Booth wrote to the minister, "There is not door in my theatro through which God cannot see." The life of the great actor was far from being a hapy one, and one of the gretent tregedies through which he was called upon to pass wes that caused by the esepesination of ereotdent Lincoln by Boothls 
handsome, resh brother, John Flkes.

It may he interesting to Louls ville people to know that J. Filikes Booth played in this oity in 1861, 1862, and in 1864, and that ho was hailed $28 a^{\prime \prime g l o r i o u s ~ y o u n g ~ e o t o r ", ~ t h e ~ " g r e a t e s t ~ t r a g e d i a n ~ o f ~ t h e ~ d a y . " ~ I t ~ s e e m s ~}$ that his reception was even warmer than that accorded the greater of the brothers upon his first appearanoe in the clty. In December, 1861, ho played RICHARD III, MACBETH, and THE STRANGER, and at that time the critic of the Dally Journal said that although he was very young, after his roice had matured; and ho had conquered cortain mannerisms, he would be very great. In 2862 the plays included HANLET, THE MERCHANT OF VENICE, THE ROBBERS, and RICHARD III. In keeping with the general enthusianfelt toward the young actor, it was declared at that time that in RICHARD III he gave the best sustained personation of that cruel king which hid over been seen in the city. And that In the face of the ouct that his brother had played the part in the city several years beebro. The final engagement of J. Filkes Booth in Louis was in January, 1864; when he appeared at Foods' in RICHARD III, DAMON AND PYTHIAS, MACBETH, and Lout Svillo saw no thore of the actor sho was all but ready to idolize.

The flrat time Edrị Booth played in Louisville was on April 26, 1868, at the Loul sville 'Thentre, and his first character portrayal was that of Sir Giles Overresch in A NET TAY TO PAY OLD DEBTS, a part in which his father had excelled. After seeing the performinee of thit play, the critic of the Daily Journal was stisfied that the mantle of the father had fallen upon the son. The flrst ongagement lasted two weaks, and Booth performed in BHLET, RICHELIBt, THE TAMTNG OF THE SHRET, THE ROBBERS, KING IFAR, THE APOSTATE, RICHARD III, and took two benefits, the first in THE IRON CHEST, and the second in MUCH ADO ABOUT NOTHING. In December of the same year Booth played another engagement of two weoks at the Theatre ith practicelly the same repertolre with the addition of MACBETH in which Mrs. G. "H. Gibert playod Lady Macbeth." It. 
appeararice was in Hovember, 1867. Durling that engagement he had with him as his leading woman, Mary MoVicker, whoim he married in 1869 . Ho was greoted with enormous eudienoes, and besides the plays which he had played before he of fered THE STRANGER, OTHELLO, and THE MERCHANT OF VENICE. Of his performance of RICHELIEU on this occasion there was but one oplnion - that there. was but one Richelleu, Edwin Booth.

Booth closed the first oeason at Meouley's Theatre in April, 1874, With productions of HAMLET, RICHELIEU, RICHARD III, OTHELLO, the STRAHGER, and NACBETH. In 1876 ho played KING LEAR again, also KATHERINE AND PETRUC BIO (as the TAMING OF THE SHREF was frequently called); and Claude Melnotte in the LADY OF LYONS. In 1877 he was seen in two new plays, HERRY VIII and BKOTUS OR THE FALL OF TARQUIN. It was not until 1882 that Lou is vil10 was treated to a sight of him again, and when he came in 1887 he had enormous reception. On the night he pleyed ofrello during that ongagement Macauley's had recelpte amounting to two thousand eight hundred and ninety-six dollars and twentyfive cents, and for the thees nights of his engagement, February 10, 11, 12, 1887, he played to a total of almost nine thousand dollars. At that time the press took occasion to ropark thet an actor who could comand such adiences should be a little more careful about the staging of plays and about the quality of the supporting compeny. Both should be made worthy of his acting.

One of the most memorable events in the history theatre is the time when Booth and Barrett appeardd at the Auditorium In 1889. The two had appeared at the Exposition in May, 1888, with marvellous success, but their eppearance during the fall festival of 1889 , was an even greater event. Months before the engagement plans were on foot to make it a vast success and one mamorable in the annals of Louisville history. All the summer long carpenters and plasterers were busy making the building ready to recelve the vast audiences which were antlcipated, and as early as in May announcements vero made of the plays whil ch the firo sturs were to paly 
In patomber. The reek of September 23, 1889 , wa the appointed tine for the event, and Louirvilie ali on tiptoo by the time the day for the first performance arrived.

The seat sale for season tickete took place on September 2, 1889, at D. H. Baldwin's store, whore seats forothe Auditorium rere always to be had whenever an attraction was playing there. No one person was allowed to purchase more then twenty season tickets, and each person was given a number so that each chose his seats in the turn in which his number came. No more than ten dollars in silver weuld be accepted from each purchaser; no tickets were laid aside; and none were exchanged after having once been selected. The scale of prices for season tiokets was as follows: orbaditra seats, dollarsirdiess circle, twelve dollars; baloony, twelve dollars. The purchasers were permitted to divide up thelr seats in different locations so long as the number of teketgupurchased did not exceed twenty. Previous to the sale of seats, it was alld that there had been the largest demand for seats known for any dramatic event south of the Ohlo River. Mr. Young E. Alison held number one at the sale, and his proxy purchased for him the seats in the first row of the dress clrcle to the left of the stage. Only one person was allowed to purchese more than the allotted tweaty tickets, and that person was the representative of Miss Annie Nold who purohased twentyfive seats in the dress oircle for the pap1ls of Niss Nold's school and four seats in the parquet for Hiss Nold herself. This purchase was permitted bocause it was known that the ticketpwere not to be used for purposes of opecuation. The entire seats sale for senson tickets on the first day amounted to eighteen thousand dollars. Single seats for the performances went on sale on September 16. General admission to the theatre was one dollar.

Booth and Barrett reeeived trenty thousand dollars for their eight appearances, and in the middle of ch perforace a check for two thousari five hundred dollars was handed to their representative. The Auditorium

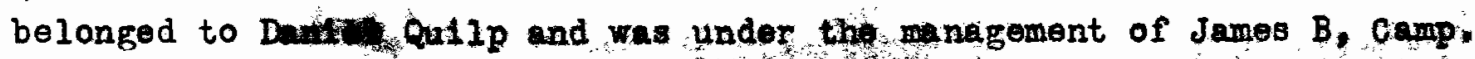




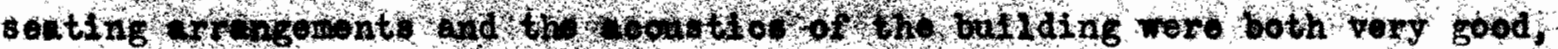

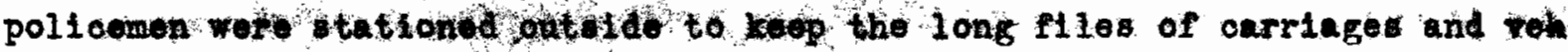
hides moving a thoy omo to and left tho theatre. It is doubtril if Lou isville efor assembled more billint of pore enthuscestio audi ances then those which witnesed the performuces of the grot gotors during the week of september 23,2809, the story le told of tro young ladies, who, when thoy firsit hoard of the promloed treat, began to save all the money they could sperejin order to paretive tickets for the groat orent. Then tho timo

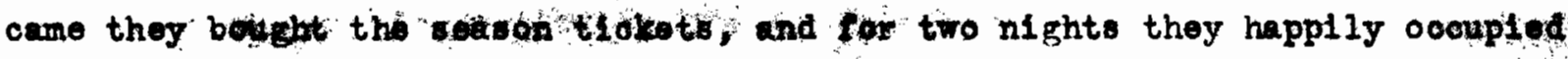
them. The affalr cam to the knotredgo of How quilp who imodiatoly placed

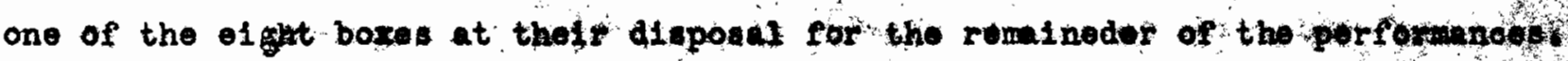
Mr. Quilp himself always ocoupled one of the boxes alone.

The compuny vhloh orme with Booth and Barrott numbered among 1 ts mom-

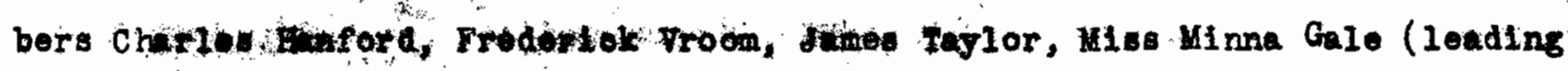
romen), Miss Annil Prooter, and Miss Apnes lores. The sconery was very gorgebasand in ontire keepling wth each production.

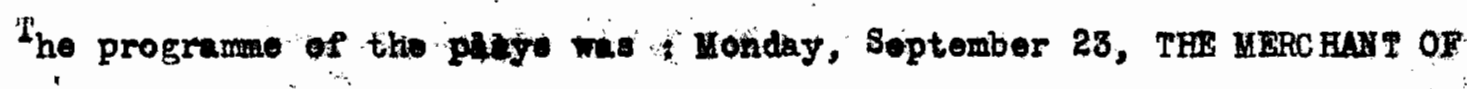
VENICE (Booth as Sholook; Barrett af Busanio)'s. Tuesday, RICHELIEO (Booth at

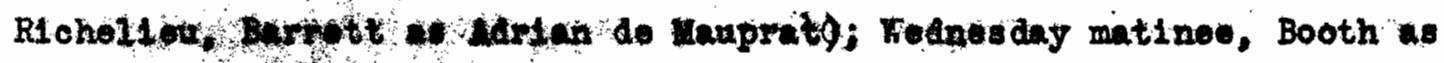

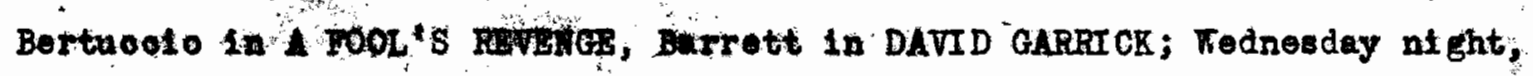

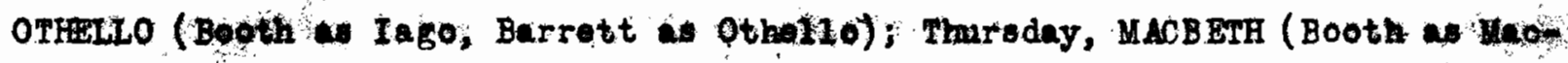
both, Barrott as Laoduff); Fridey, Humbe (Booth as Folot, Barrote as Laortes); Saturday matinee; IJe ADO ABOUT HOTHINO (Booth as Bonodick, Barrott

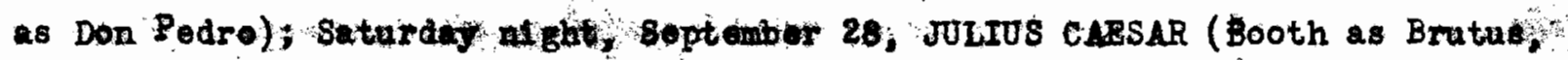
Barrett ascosius):

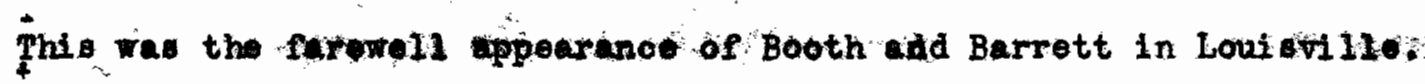
Barrett never came agin, and Booth one only once thereafter. Booth wa the greater actor of the two; but Burrett the better business manger, and the combination was an ldeal ore while 16 Idstody

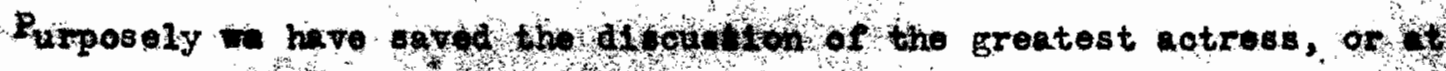

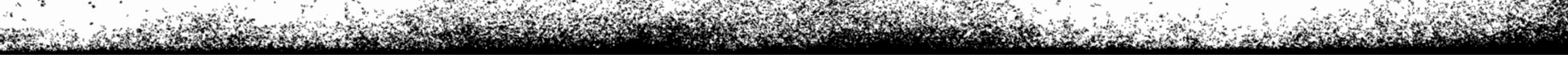


any rate the best loved actrese that Laziorillo has over known, until the last, Mary Anderson mate hor debut and first appearanoe on the stage of theatre at Maceul eylo seturday night, November $27_{2} \cdot 1875$, in ROAEO AND JULIET with $\pi$. N. Geiffith as Romeo and Milnes Levick, a really excellent actor and a star of the time, wercublon. It is not often that a beginner in any line of endeavouris halled with the enthusiasm which Mary Anderson recelved, and there, mist have been e great deal which was umusual and gave ovident signs of greatness in that performanos of Juliet, for the Courter: Journal on the mornitg foldowing be first appearance was loud in praise of the sixteen year old girl and prophesied the success which did oome in such great bundance. There wero 11ttle dofocts notod, such as too froquent casting up of the oyes, but the critlaien was really very helpful, generous, and most kindly.

During the week of Februnry 21,1876 , Mis8 Anderson filled her first regath theatricul engagement. Sho played at Mecouley' in FAZIO, THE HUNCHBACK, THE LADY OF LYONS, EVADNE, and ROMEO AND JULIET.

When she filled another engmgment of reek in October, 1876, having added to her liat of parts Parthenia in INGOMAR and Meg Merrilies in GUI

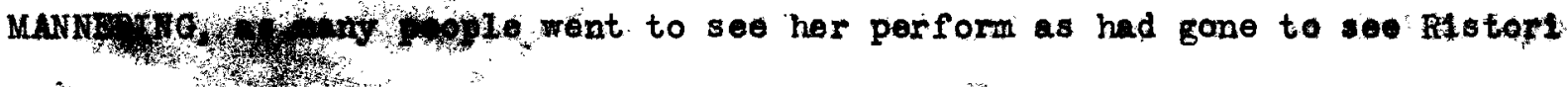
or tumaston fot was sald of hor then that she was the most promising if not the greatest actress in existence. One mut make allowance somewhat for Louisville's enthusiast for the clty did love its Mary foom the very beginning. When she played an engagement 1n Now Albany in April, 1877, erruas ments were made whereby bouts carried the people of Louisvilie to the Indiand town to see Miss Anderson perform.

In 1877 (Ootober) she ms again at uacauley's, and at that time pere formed in ION and as Lady Macbeth. Lady Macbeth was never one of Miss Anderson's great characterizations, and it was sald at that time that she painted Lady Meobeth in too dark colors, although the representation had some points of greatness in it. 


\section{$P_{\text {age }} 108$.}

Twice in 1879 Louistille knew the pleasure of seeing Miss Anderson, once in Jamary and again in December. At the latter time she was supported by a company of her own emong whom were Milnes Levick, J. W. Norton, Atkins Lawrence, Sam $K$. Chester, and Lizzie Creese. At the time of her engagement in April, 1881, she merred her impersonation of Juliet by a prolonged shriek in the potion scene. During this engagement, besides ROVEO AND JULIET, LOVE, INGOMAR, and EVADNE were given. EVADNE with Miss Anderson in the leading role was a great favorito with Louisville audiences.

In 1882 the city first saw her in PYGNALION AND GALATEA and in the DAUGHTER OF ROLAND. Miss Anderson's Galatea was one of the most exquisite personations she gave. On Saturday night, November 11, 1882, following the play INGOYAR, the Nayor of Louisville placed upon Miss Anderson's brow a wreath of laurel in the name of the city.

For several seasons following 1882 Louisville did not see Miss Anderson but eagerly followed her progress. $\mathrm{T}_{+}^{-}$hose seasons were spent in England winning the hearts of all who came within the radius of her charm. On February 18,19, and 20, 1886, she performed in Loulsville before perhaps the largest audiences which were ever assembled in a theatre here. The plays she presented were PYGIALION AND GALATEA, CONEDY AND TRAGEDY, THE LADY OF IYONS, and AS YOU LIKE IT. This was the first time she had played Roslind beforea Louis ville audience: Louisville was very fond of Galatea and considered har acting in COMEDY AND TRAGEDY, as Clarice, marvellous.

Upon Miss Anderson's last appearance in the city in 1889, just previous to her final retirement from the stage, she was presented with resolutions adopted by the State Legislature of Kentucky in honor of her and of her work. After that season neither Louisville nor any city saw her again on the stage: of its theatre, and she still lives in England in the happy retirement which she so justly earned.

Louisville has given other actors and actresses to the stage, but none of them has attained the fame and the honor which Miss Anderson won. 
Because wo have called this the Mary underson petiod in Loulsvilie theatrioal history, it soene reil to knoi a litlo about the info in louisv1le of the woman who was so very dearly loved not only in this city but In theriearand in countries across the sea. It is fitting, therefore, to olose the most brilliant ompter in Loulsvilie' theatrical history with a sketch of Louisville's farorite actress.

41 America call" Mary Anderson "Our Mary", but Louisville called her that with a real right. Sho was Louloville's Mary Anderson, oven though she was born in Sacrmento, Cailfornia. Her mothor was Miss Mario Antoinotto Leugers of Philadelphia who, when she was about seventeen, fell in love 1 th a young Englishman,just from Oaford, nmed Charles H. Anderson. Missileugers' family was opposed to the marriage, but with the help of a favorite brother the two eloped and were married in New York. From Now York they went west to cellfornie in 1859, On Jity 28 of the same year Mary Anderson was born. It was in Sacrmento a few month later that one night robbers broke into tho house where Mrs, Anderson was alone Wh her baby. The intruders threatened to kill the bhby if the mother would not give up every article of value she possessed. The baby, a friendly soül even at that time, tried to play with the mon who were ready to take her Iffo: They doparted after ransacking the house.

In $1860 \mathrm{Mrs}$. Anderson removed to Louisville to be near a very dear relative of hers, because her husband was compelied to be array from home a great part of the time. In Louls ville lived an uncle of whom she was very fond. He was Father Anton Miler, Francisean priest at the parish called New Callfornia near Louisville. This priest is the beloved "Wonie" of whow Miss Anderson speaks grequently in memories of her childhood deys. When the father, Charles H. Anderson, died in Mobilo when Mary was three years old, Pater Anton assumed care of the little family which consisted of Mrs. Anderson, Mary, and her baby brother Joer. He mathelr guardian until 
the nother five jours latertwhrlod Dr ninlton Griffin of Loulswile.

Accounts of Mary Anderson's chlldhood tell of a happy, care-free sort of existence. Sohooldaties do not seem to have bothered her a great deal, although she did attend the Ussuline convent (where at first she was desperately homostok), and later sho was seat to the Prosentation Academy. Miss Anderson berself acknomedges thet she often stood in the corner with a book on her head for misconduct, and she really preferred the dunce stool with its oushion to the hard benches of the righteous pupils.

It was during her attendenoe the tirsuline lcadeny that she made her "first appearence on any stage." The occasion was an "exhibition" at the school. The littlo Mary stood in the front row and spread her hands wide across her chest. In the course of the song which was about "iny grandfather' fine geese", she lost the tune and began to glgte. Her mother overhoard some one remerk, "Thut a funny, awkard l1ttlo girl." That incident proves certainly that one cannot argur ondings from boginnings.

Mary Anderson and her brother Joe began their theatre-going lives when Mary was about twelve. The first play she over saw was RICHARD III with Edwin Adams in the role of Plcherd. When hor mother saw how enthralled she was with the performanee she offered as a reward of merit Saturday matinoe tokets for Joe and Mary if they woro holprul and good during the reok. Shortly before this prontse Mery had made her acquaintanse with shakespeare when Dr. Griffin read HAMLET aloud to hor. Encone ovening following this reading Mary appened before her amazed fanily wrapped in one of the doctor's big army cloaks, deolaiming

"Angels and ministerá of grace defond us :

Be thous a splrit of health or goblin demned," . reading the 1 ines

"Angels and minstrels of graoe defend us!

Be thou a spirit of health or oblin's dame" 
The attendances at the thatre were great jps. It was the old Louisv1110 Theatro at Fourth and Green (tiberty) Streets which she attended, and the door-keoper came to know the two l1ttle persons so well that he would often let them into the theatre full two hours before the performences began so that they night enjog to the full the expeotation which the empty house heightened and might wonder about the weteries which went on behind the heavy green ourtain.

Then Vary Anderson wes fourteen she saw Edrin Booth play RICHELIBU ( At Macauley's in April, 1874), and on that night when she went home, instead of golng to sleep, she mapped out in her mind her career. From that time her determination and her ambition to become a great aotress nover lessened until she had attained her desire. She began the study of the volce and how to strengthen 1t; she studied Shakespeare Industriously and worked hard at other lessons which had been distasteful but which she felt might be useful in the life which she had planned. She told no one of her great ambition, unt11, when she could keep the secret no longer, she revealed it to Juli, their little colored maid. And it for Jull while sho was washing dishes in the kitchen that Mary Anderson first pefformed some of the cenes in famous plays: Her first applause came from the sopp-audsy, warm, brown hands af $j_{u l i}$, who, when she had seen the performance of the last acto of the IAII OF LYONS, insisted upon calling Mrs. Griffin. Dr. Griffin, too, was called in to criticize, and after that the young actress gave performances of RICHELIBU, RICHARD III, and Schtller's JOAN OF ARC for her family.

$D_{r}$. Griffin was acquainted with Mr. Wond, the chiof comedian at Macauley"s at that time, and ho persuaded fond to come to see Mary aot at home. She playod in RICHARD III for him, and the actor was most enthusiastio and secured for her an interview with charlotte cushman who happened to be playing in Cincinnats. Mary and her motherfort to cincinnati and were enFalled by Miss Cushmen's wonderful performinases. Mrs. Griffin was opposed to hor daughter's going upon the stago, but tho girl was determined. Miss 
Mas Cushnan hoard her read, grve het sowe rery good adiloo; and prophesied that in two years Nary inderson would be before the public. The propheoy was fulf1lled. She also advised the girl not to begin at the bottom as ms the usual custom, for that he saw would crush hor, but to pley leading parts always. Hhosecushman advised sertes of lessons from Mr. George $\nabla_{a}$ ndenhoff in New York to "clip and tame her generally."

Following Miss Cushan's instructions Mary and her mother went to New York where the girl for the firat time met her mother's parenta. These old people, as well as the moh loved "Nonie" were opposed to the theatre, and so they were not told of riary's ambition. "Nonie", almost until his death, refused to forgive or to seo her unless she gave up the stage, and the estrangement with him"cast shadow over all tho otherwise bright and happy memories who was the father, friend, and pleymate of our childhood's days." (4 Fen Memories - Mary Anderson - Page 52.)

While she was in New York Kiss Anderson took ten lessons from Vandenhoff, who did "clip and tame her," but under whose instructions she became very restless, although she realized the great hipp the lessons were.

When the work was finishod, Mrs. Griffin and her daghter returned to Louisville, where for aix months the youing aspirant acted alone, using chalrs and the chandos bust of Shakespeare as her supporting company. Miss Anderson whimeically remarked that the bust seomed less stony when it impersonated Romeo. (A Few Memories - Mary Anderson) Thts work wes done practically without critlcism excopt thet of Mrs. Griffin who was as ignorent of the rules of dramatic art as the girl herself. Often Mary wont to Tave Hill cemetery and spoke Jullet's lines through the door of a vault in order to get the hollow tones of Jullet's volee in the tomb scene. A year of this "In many ways useless labor" wont by, and still no engagenent seened forthcoming. Mr. Fond ha left Moeuley's, ind there seemed no means open to secure an engagement. At about that time John Mocullough was billed to appear at Macanloy's. 
Mary wa linost 111 with werpinesond ditcouragement, and Dr. Griffin determined to take matters into his own hands.

He matered his pride, and thout an introduation, rent to the actor and told him of his daughtef's work and hor trouble. Mocullough, as was doubtless notural, did not. Itke stage-pteral poople, and when he finally consented to hoar her, it was more through desire to be rid of Dr. Griffin than through any interest in the affair. Thecactor said that he could spend but a quarter of an hour, and that ho would criticize severely. Miss Anderson played for him the potion scene from ROMEO AND JULIET. By the end of the scene Mecrilough's attitude had ohnged entirely, and he remained at the houee for several hours acting soenes th her from ell the plays she knew.

The famous aotor took M188. Anderson and her father to the theatref and then 1t was that Mary Anderson saw her first rehearsal of a play. McCullough alfot introduced Dr. Griffin and his daughter to Barney Macauley saying. "Barney, when you can, put this girl on the stage. If I am a judge of such matters, she will make a fortune for you. "(A Fow Menories 4 Hexy Anderson - Page 48.) Mccullough himself offered her the part of Ladjoftite in RICHARD III, and he was amsed when she refused because she would not play second fldale oren to hin.

There faliawed enother period of lonely atudy, cocompanied, Mias Anderaon says, by earnest prayers. One norning during November, 1875, on her way howe from the cathedral, she and Dr. Grin alineed to meet in front of Mr. Maomleyls house. They determined to askepout an engagement. The mager was ploased when they proposed glving her arial. It seomed that the stax of the week was not drawing rexy large bouses; and unless he had one good house before the week mas over, he might not be able to leave the city. in agreement was reached on tharsday, and after obtaining Mrs. Griffin's consent, the arrengements were made that Mary Andereon was to appear as Juliet on the followlng saturday night. She wav to weelyy no pay, but Mr. Macenley was to furnish the theatre, the actory, and the mistc, fred 
On the next day, Friday the first and only rohoarsal of the play ins held. On her way to the cathedral on that morning Mis inderson sas posted on the fences the bills announcing the plays for the Thanksgiving matineee and for Friday night, and stating that on Saturdey night, November 27, 1876, "Miss Mary Anderson, joung lady of this olty, will make her first appeurance on any stage as Juliet in Shakespeare's RONBO AD JULIET - Milnes Leviok as Mercutio and a powerful cast of charecters." The advertisements in the newspaphers road in much the same fashion.

The first time that Mary Anderson ever set foot upon the stage of a theatro was at the rohearsel on Friday. The professional actors did not relish the extra rohoursal and made tor rather unploasant for the girl. "On seeing me all looked warptised. Sam made remarks in whispers which I felt to be unkind; othere laughed audibly. Scarcely sixteen, my hair in a long brald, my frock roaohing to my boot-tops, tall, shy, and awkward, I may have given them cause for merrieent; but it was as oruel, I thought, as unbred, to make no effort to conoeal their mirth at my expense. However, their rudeness was salutery in 1 ts effect, putting me on my mettle:before the work began". (A Few Memories - Page 54.)

Then the ectors wanted to hurry through the reheargal and did nat wish to do the tage business as she had worked it out. Mr. Macauley, however, made them do as the girl wished, and the rehearsal progressed sulkily. One man remarked thet he had played in the play before she had been born, and tho whole company was with three exceptions "the most dogged, coldly uninterested set of people" who "sneered at her every movement or suggestion. It was a relief to turn from them to that excelient artist and true gentleman, Milies Levick, and to watch the earnest care with which he rehearsed every line."

Miss Anderson went home rudely awakened from the beauticul dream she had been dreaming and dreading the saturday night. But when the time came, matters were not so dreadful as she had expected, far the actors were not unfriendly thop, and the tage, with its scenovy, wa different. Miss 


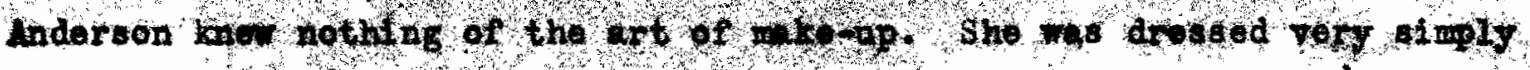
and Fore no ormmenti.

Curlosity had fliled the horise and remprks of surprise ran through the house upon her first appoarance "Thy, It' I1ttlo vamio Anderson!" Hor

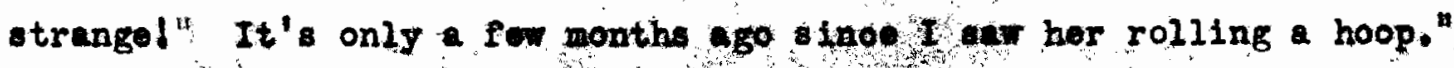

Mary Anderson telle tho otow of thit first night thus:

"The enrly, 11ghter scenos, belng unoongeniel, I hurried through as quickly

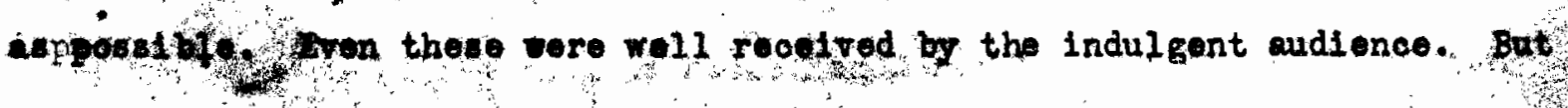
there wo onthiflasm in the houge rhen the traglo perts were reached. Flons

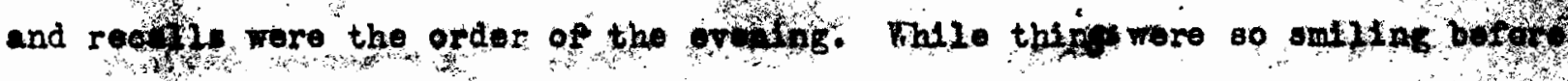
thay were less satisfectory bahind the curtalin. The atcictutho had acted ix the play before Iy birth forgot his worde, and I had to ppompt him in tro: 1mportant soenes. In the last ect the lagp that hangs above Juliet, as wo 1108 in the tomb, fell and traped wayds and dress bedly, and to make matters vorse, Romeo forgot the dagger with wich Juliet was to kill herself, and thet unfortunate young porson hed, in deaponation, to despatch herself with a hair-pin. But in spito of mioh distilupion, burnod hand and aring several other coldente tho night mo frill of uocos, and I know that

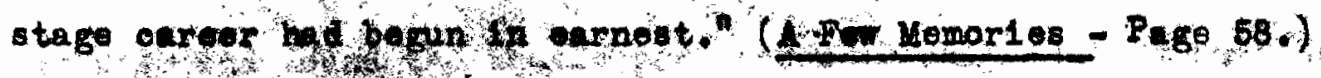

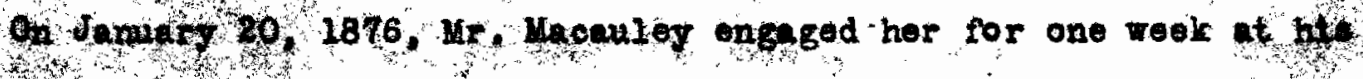

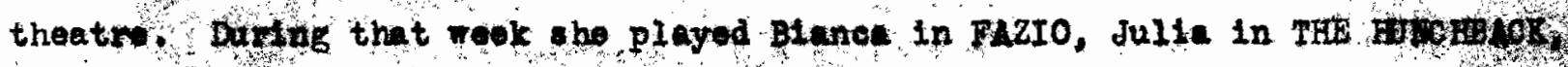

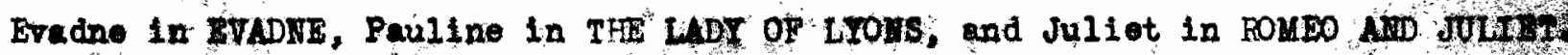
It the end of the weok sho ras 1 in dobt one dollar to Mr. Macanley.

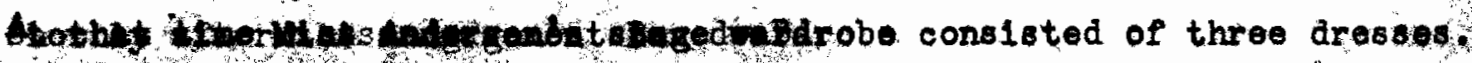

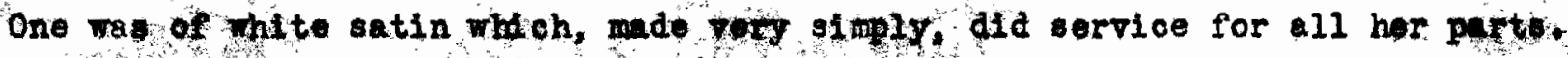
It had eliver triming for Jullet, plak roees for Julia, green and gold for Evednes, and thite lace for Paline, sho wa lso supplied rith train of white velveteen, ahte waln dros, and a bleck silk gom in the fashon of the day Her mothor ras har costame destgner and offected the changes

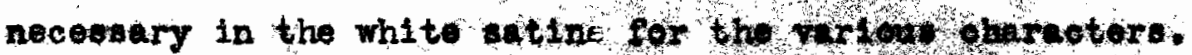


Shortly after the engagement thoulde's Ben do Bar ( one of the groatest of Fulstaffs ) engeged Miss Anderson for six nights at his st. Louls

- Theatre. At the ond of the reels ohe was six hundred dollars in his debtl. Defurgethertheless, engaged her for tho following week. to close his st. Charles Theatre in New Orlenns. The beginning of thewreikidid not seen very promising, but by the ond of the time, the audiences were larger, and Mrs. Chanfran offered M18s Anderson the next veek et hor Varleties Theatre provided that the would study and present Meg Herrilles in GWY MANNERING for her benefit. The second week was a reritable triumph, and at the banefit she recoived bouguets and baskets of flowors with chocks and money hiddon in - them and was presented with the mich coveted Fashington Artillery Badge. The railroad company placed private car at her disposal for the return to Louisville. Her first suocesses seomed very great, indeed.

During the following sumer Miso Anderson played an engagement in Orensboro. Of thi engagement she relates anding incident. a little negro boy had been hired to sit on the top of a sep-ladier behind the scenes and hold the search-light of an engine whith to ropresent the moon in certaln of the scenes in ROMEO AND JULIET. The little fellow begame so engrossta is the play and found the tragie portions so highly amaing that he forgot the importance of his offlce and sllowed the moon to sway about in a manner which oaused its rays to flood the boxes, the orchestra, and every part of the stage except the face of the hapless Jullet whioh it was meant to 11 lumine.

The engagement it Maceuley' Theatre in Junuary, 1876, began Mary Anderson's tage career, and for thirtien years she was an actress, She becane frmous both in America and in Great Britein. Her career from the tims she left Louisvilie is a matter of Ameriean otage history. For throe seacons, $1883-84,1884-85,1887-88$, she played the Lyoerm Theatre in London, but she had elght sousons of steadily inoteasing popularity in Ameriou before

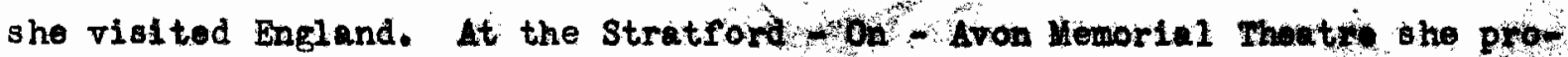

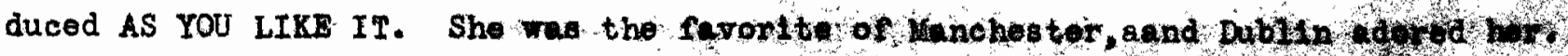


Tet Ith her grent love for the drith and the art of acting, very early in hor career, Hary Inderson began to foel great dislike for the public life which her profeseton compelled hor to lead. This disilke increased as the seasons phesed. In hashington in 1889, weary and exhausted to the point of 111 ness, Mary inderson gave her final performance on the stage as thrmone and Peralta in A FINTER'S TALE. On June 17, 1890, she was married to Mr. Antonto de Navarro in London, and they are still 1171 ing In Foroestershire, England.

During her years on the stage Mias Anderson played many parts, but her most fanous chmoterizations as rocorded by Mr. W1111am Hinter weve Jullet, Hermione, Perdtta, Reselind; Julle, Bienca, Evadbos, Parthenia, Peuline, The Countess, Gelatea, Clariee, Ion, Meg Merrilies, Berthe, and the Duohess de Torremera.

Crities differ as to the quality of Mery Anderson's acting. Mr. Hornblow finds that "partioularly in Galaten and as Pordita in the WITER'S TALE her success was complotak udionoes mantwild over her. Yet she could not be called a great aotress: Her histrionjo gift lackod versatility. Atall times she satisfied the heart and gratified the oye, but she did not always succeed in simuling the deeper or more intellectual omotions." (tornblowA History of the Thentre in Amertor - V. 2 - page 263.)

Tone gives an interenting description of her persenulitywas well as a critlalim of ability. "Then mero girl she first entered upon the stage, he presented a figure of clessic and virginal purity that was almost 1denl. Hor tall, 11the form was at onse stately and graceful, the polse" of her head was stag-like, and her face was radiant with health, innocence, and dignified bewty. It was by the spell of her personal charms that she instantry. made hop way into the hoart of the American publio, and she rotired to a. happy and presperous propeçe when still at the hight of her popularity whilo that spell wa yot potent. A finer type of young Aneriean womanhopdccould

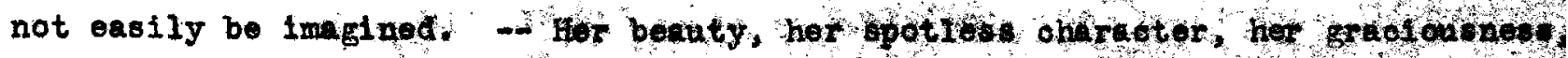




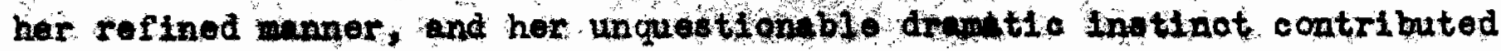
greatly to the honor and glory of the Anertaan stage while she adomed it; but for all that, she was nover a great actress or a great artist. -- Hor voice was always one of the most potent weapens in hor artistic armory. It was rich contralto, thoroughly fomintine, but unoomonly dell, doep, supple, and melodious. She knewrhir to arail herself of its finest tones, and conseguently her delitery of blank verse was not elways proof against the charge of monotony - bat she often enploged them to splendid purpose.

"She had certain formules in which sho was proficient, and sho applied. them to correoponding types of siturtion with a deadly and unmodified ro1teration. In the mecknism of ber art he never advanoed beyond a moderate poofictency. What she had loarned to do she did well, but hor executive El. ability wa rigldly limited. It oeased to expand. In it she revealed neithar invention nor ingenuity." Sho was always Mary Anderson." In great parts demanding imagination, passionate eloqueno, or subtie disorimination she was second-rate." ( J. Rankin Towse - Sixty Years of the Theatre - Pages 214 ff.) Augustus Pitou also recognized her recknesses, but remarked that "had she remained on the stage, she rould have perfected her art; and she.would be to-day our groatest actress." ( Mhatery of the Show - Page 100.)

Mr. W111um Finter, very good friend of Miso Anderson and a most it excellent orltio, replied to the oritiolsm conventionally offered that Mary Anderson's acting was" cold" in these words: "When a woman appears on the stage whose iffe is not ruled by the love of admiration, whose nature is devold of renity, who looks with indifference upon adulation, whoge heed is not turned by renow, whose composure is not disturbed by flattery, whose tineplicity ia not marred by wealth, who does not go into theatrical hysterios and offer that condition of artifloial dellrium as the mood of genius in aoting, who above all makes it apparent, in her porsonality and her achievements, thit the soul can be suffiofent to 1 tself and an exist without taking on burden of the fever and duthees of other 11ves, there is a flutter of rague diseon- 

C H $\triangle$ P T E R V.

THE THEATR IN LOUISVILLE

$S I N C E, T H E$ TIME O F

MART AN TEERSON

$1890-1921$. 


\section{CHAPTER V.}

THE THEATRE IN LOUISVIULE SINCE THE TTME OF MARY ANDERSON. $(1890-1921$.

Since 1890 there hat been it the theatre in Louisville, as in the theatres all over the country alstinot though gradual change.

There have been way merr theatres built and old ones have passed out of existence, but one theatre in Louisville still lives up to the standard which it set at the time of its openting - Moanley's.

In the nineties the Avenue theatre on Foorth Street was bull, and for many years during the early part of the new cantury, it was operated as a theatre with colonel feffert's stock company. Another popular stock company In Lou to as they were reorganized after their disappearance in favor of the road companies vere differgt foom the older organizations. In the old deys the stook company merely formed the beokgand fer the stars who traveled from theatio to theatre, but the stock coppanies of the later days remained at the theatre performing $1 \mathrm{a}$, fow play each weok and independent of stars. The plays wore wouelly those which had been popular in the higher-priced thentres, and stIII how dwhthy power with less offichent companies at chepper prices. Many of the stodk companies, however, wore really excellent, and as a training school for actors they rere unexeellod. Almost every actor of tha nineties and the early years of the twentieth century had served an apprenticeshdp in H took company.

Whe of the newest and most beautiful theatres in Lou is ville is the ane which used to be knom as the Shubert-Mesonic. It is located on chestnut Street noer Fourth, and was opened in 1902. For sereral years it was the home of the shubert productions when they visited Louisville. The Mesonie is now callod the strund, and it is operatod as a moving ploture theatre by 
the B. F. Solth Intereats.

The Wesonio 1 o rell-built and exoellent theatre, and Lou isvilie hopes to soe the day when it will agath be derotod to the uses of the logitinate frame which It men in its first dogs.

The Falnut Theatre us opened to the public at the beginning af the season in 1910, and for several yoars it wa given over to the presentation of plays at modente prices, but in 1914 , 1 t, too, became motion picture thent re, touts ville at present (1921) hes two vaudeville houses, both under the control of the B. F. Kelth fiterests. The Mary Anderson, on Fourth Street near chestrint, offers what is known as big time vaudeville, whlle the Vational at Fifth and Falnut Streote, Louiovilie's norest and largest theatre, presents a combination programe of vauderilie and notion pictures. In the sumer the Mary Anderson is also used as ploture theatre, and several years ago it was used throfhtut the jear as a picture hows.

We buve previcasly mentioned the Boplatns Theatre which was one of the afty' arllest raudeville theatres.

Several years go tho Bucklinghax Thoutro as name among Louispille theatré passed out of existence. In 1919 and 1920, and for a time in 1921, it was operatod as the Jefrerson, but at present it is not open.

The Grety thostro, which was oponed in 1900 as a burlesque houso, continues that polioy, although for a brief time it presented plays hgted by second und third rate theatrical compantes at a very low price of admitosion.

Tho onde of the tppepenrance of tho stook companies in Louisville, and in prootically orery olty in tho country is not far to seok. The people found in the pleture how oheaper, ant for time, more novel amisement, and they deserted the etock bhatres, fren for a time the effeot of the motion ploture was felt upon the theatres presenting the very best dramta offorings.

Lonistile's first motion pletare house was opened in 1804 . It ras

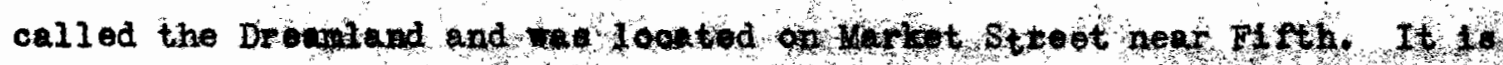




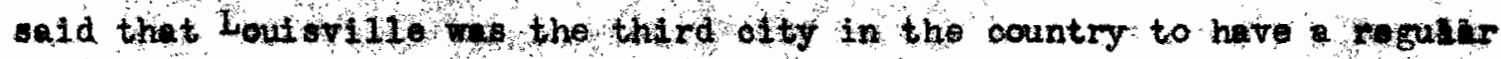
pleture theatre. The venture proved great ancess for Mr. Irvin C. Stmon Who Introduced the now pasenent inte fou lstslie. He forned with Judge W. Allen Kinney a compeny knom as the Princess Amusenent company wich soon opened the columbia, the odsfogand the Orpheum theatres. The latter two are still operating as pioture shows, but the columbia and the Dreamland are gone.

The moving pieture 10 in Its rent sarliest infancy much as some perbons 1ike to speak of the gloxfore tocomplishments of the screen. And bing in its infanoy 1t is hardiy fair to gage itobctiomplisments by the side of an art which has existed for onfurbas. It is, approximately speaking, only within the last ten yeaps that the men who pictures have begun to reallze the possibilities of the medum th which thos are working. It is not many jeart

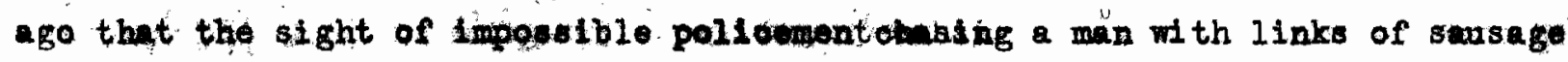
hanging from his pocket was enough to send an eudiences into convulsions of laughter. But there have beon pletures like the BIRTH OF A NATION which neuse observers to hope for better things Harold Trowbidge Pulsifer in an articlo in tho Ontiool fo Jenuary 19; 1921; charafterize the movies we the world's worst fallure, if they are to be considered from the standpofint of artistio ehilorement. Be that as it way, it has become the fashion to blamo everything whiteh goes wrong in the morals of the country, atate, or a olty, upon the movtas", and In mensure thoy are doubtless responstble for ming of the velre Ideps which orop into the mands of some people. But it mast be seid, in defense of the pletures and in defonse of the people who watch thes; that the pottators do not take the novion neatly so seriously as some other persons Imagine. There are, it is twe, plotures morklly wrong jwet as there have been ploye which were morally wrong, but the great mistake which it seems many peoplo make is to put the ploture shows on a par with the dramapor the legitimate thedtresand pass judgment upon the former as a rival of the latter. The motion ploture ilil nover the the place of the spoken arome th 


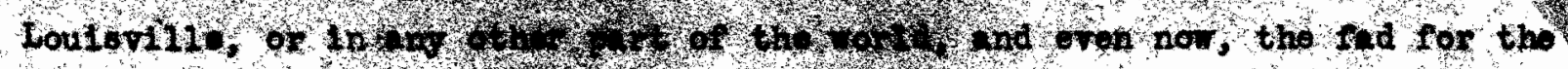

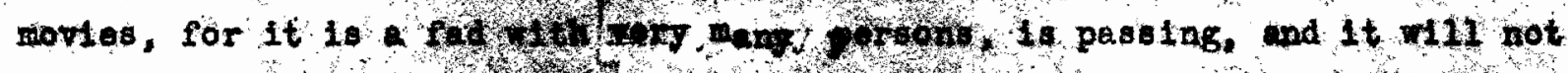

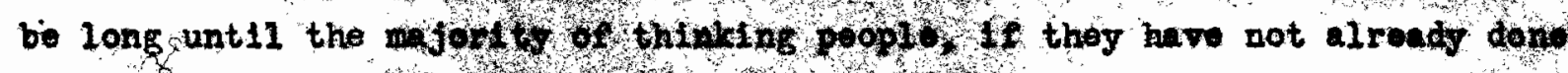

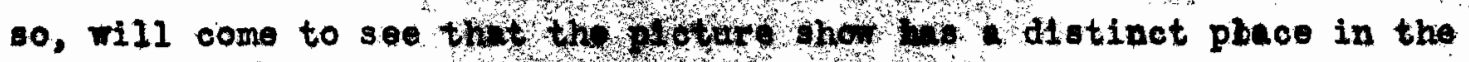

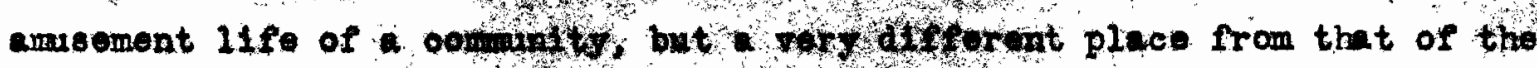

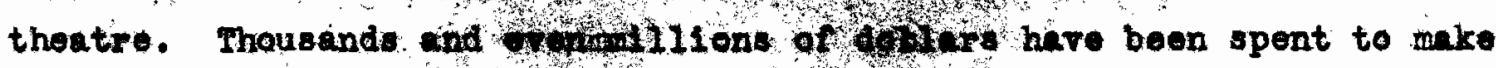

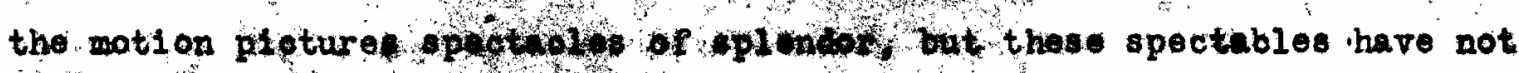

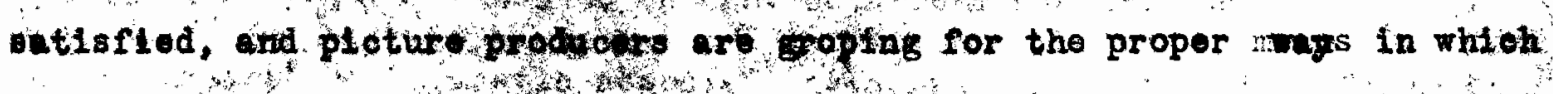

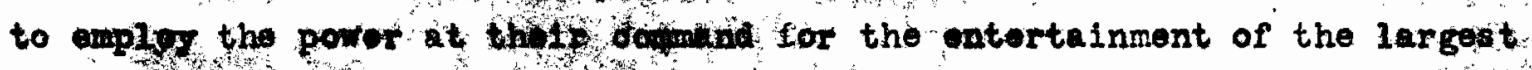

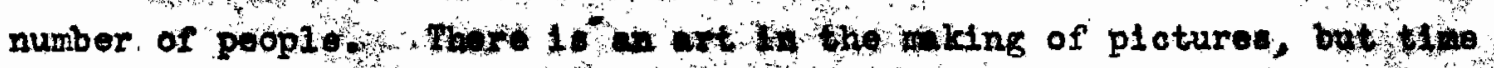

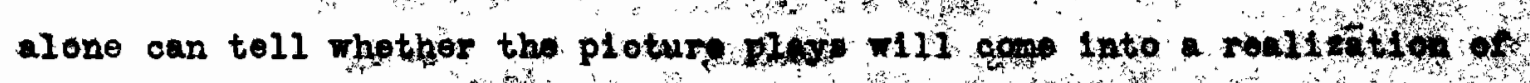
their own atsuton of nat.

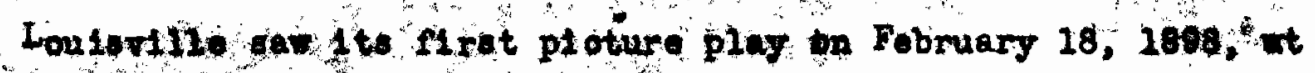

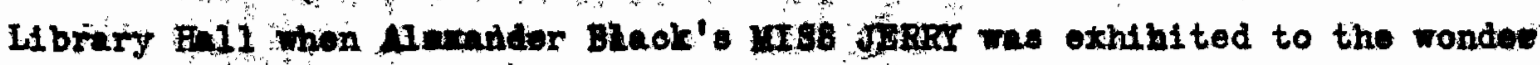
of all beholders. The otory was advertined es fletion, but the pictures wore of "real people and of real seones." Loul aville had to-day literilly. scores of pleture thentege, and one of them ure very beautiful onos, too.

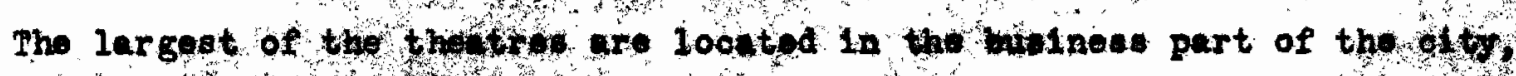

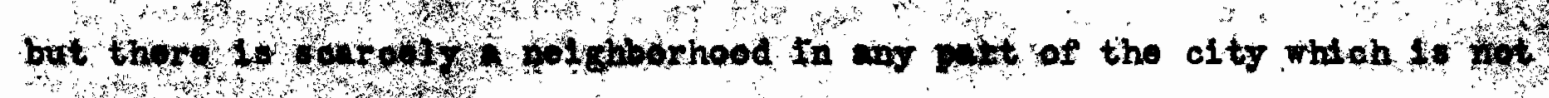

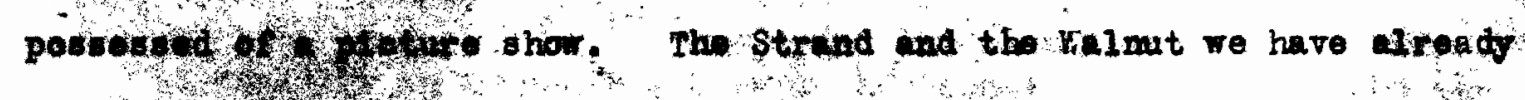

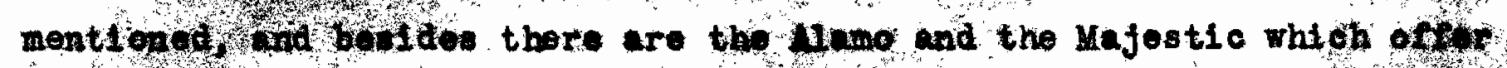

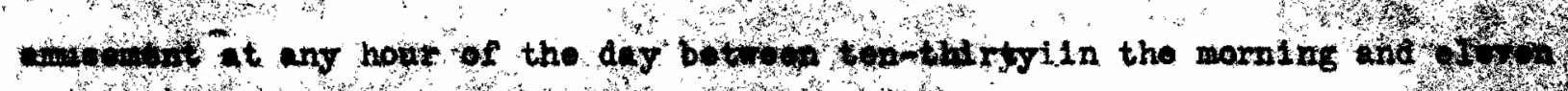

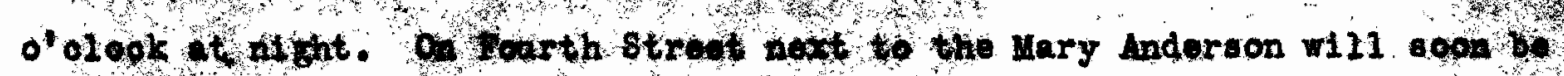

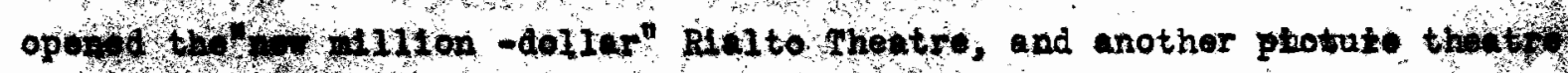

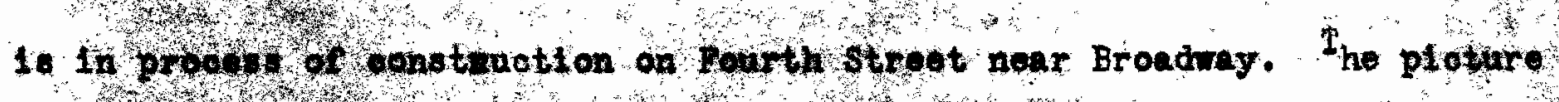

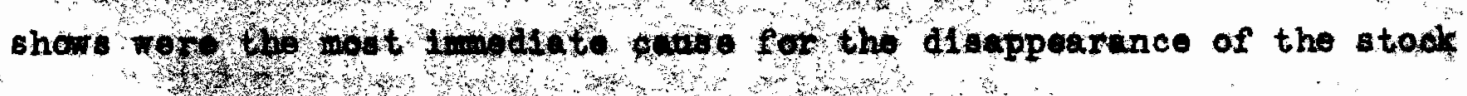

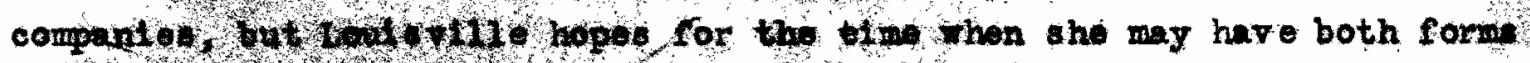

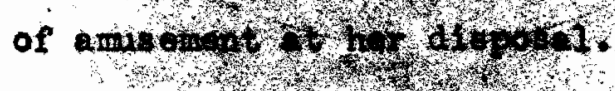

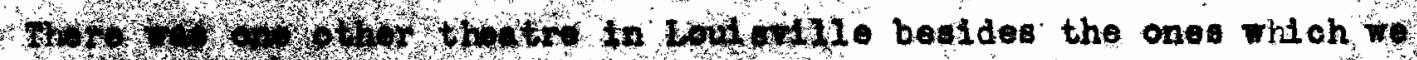
have ment 
Kner many wemoreble pexformanoes before 1 to disappearince in 1904.

It was in the matorium that Edirin booth mo his last apponfances in Louisville in May, 1890, playing with Madne Lodjeska. It has housed concerts by Victor Herbert's Orbhestra, by Damosch Orchestra, Sousa' a Band, by Melba, Schamann-Helnok, and by Patti to mention only a very fer of the many misical organizations and singers tho appeared there. It knew wany seasons of opera, and was wed on many oceastons for the performances of amateur moical and dramatic assolationt. Hrs. Fiske performed there in BECKY SHAPP In 1901 and In HARY OF HAGDALA in 1903, In 1903 Henrietta Crosman was seen there in THE SFORD OF THE IITEG and Feber and Flelds with Lillian Fassell, Fay Templeton, Wiliam Collier,john T. Kelly presented TFIRLY VHIRLY and the BIG LITTLE RRIVE ESS there furing the same year.

Loulsolile has roeently aquired a now municipal Auditorium which is located on Broadway near. Boook Street. The luditorium was bullt in the fall of.1920 for a great revival cuatuded by Gysy Smith, and it was then given over to the city to beuused as a gathering place for many kinds of puxposes. Several rery dxeellent concerts have been heard there during the pest season, but it 18 doubth the new Anditorium everequalisthe brilliant history of the old one.

It rould be in 1 mpossible task to mention all the players and tho plays in which they have appeared during the last thirty years at the rartowe Louisville theatres. Macauley' has had, as is natural, a larger numbrof stara upon its stage than all the other theatres combined.

Real opera companies are not so numerous and, therefore, do not make as frequent appearances as in the early days, but one of the most notable opera events of recent years was the engagement of the Boston Opera compan and the Bavioma Ballet at the Masonic Theatre. Among other pperastiere

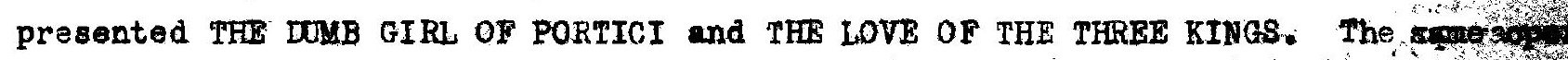
company appeared again the following year et the fational Theatre offertw 


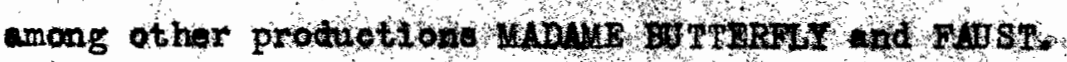

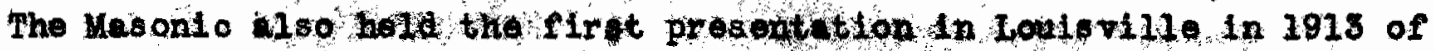
Meeterlinok's BLEE BIRD, and Sothorn and Maplowe eppeared thore prequently

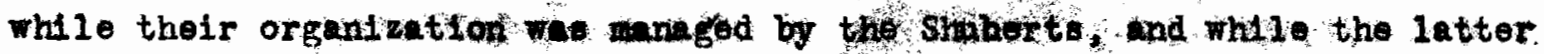
directed the destintes of that thentre.

Tith comio operas, mustoal comodter, rowios, spectooles, and extrava-

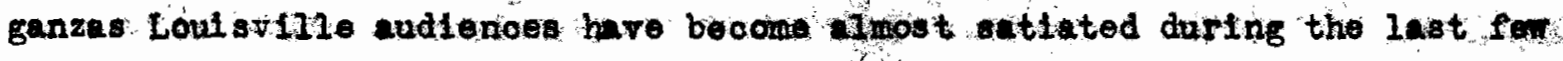
yeare. Tro plays in whoh the poctacules olement combined with pageantry wa prominent were the GARDEN Of LIAH, whi on hes visited the city a nuber of timos, and JOSEPH AND HIS BRERHEW. The latter play was particularly good When presented at Meculey's in 1914. In It James $0^{\prime}$ Neil, the famous Count af Monte Cristo of the seventies and olghties, made his last appearance in Louistille as Jacob. The other stars of the east were Brandon Tynan and Pauline Frederick.

Loulaville saw Ellen Terry and Sir Henry Irving several times; one of the list appearances was made in ROBESPIERRE in Fobruary, 1900. Siv Johnston Forbes-Roberts on and his wife, Gertrude Elliott, were seen in CAESAR AND CLEORARR, agd during his last ongegement in Loulg Pville the distinguis hed Engllohmen played in HAMLET and THE PASSING OF THE THIRD FLOOR BACK. In Mroh, 1901, Sarah Bernhardt and H. Coquelin visited Louisville performing In Bostand's L'ATGLON. Mademe Bernhardt hes appoared in Louferi11\% sines thet time, and efisidnt unresonahle to expect another faremell tear.

The Nat Goodwin and Maxine plilott partnership presented in Louisville such plays as AN AMERICAN CITIZFH, THE GEYTUS, NATHAN HALE, and THEN RE TERE THEHTONE. Alohe Mr. Goodwin visited the eity many times, and his last appearanee thore was in 1914 in IEVER SAT DIE.

Raymond Htohcok in KING DODO, RAchard Carle in TFE STORKS, and both of them in wamerous other pleys have vielked Loulsville on many occasions.

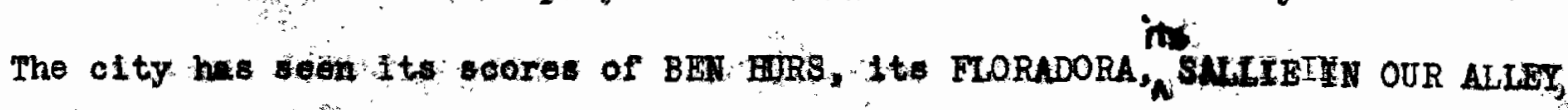




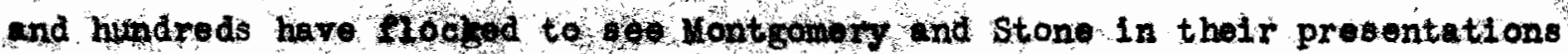

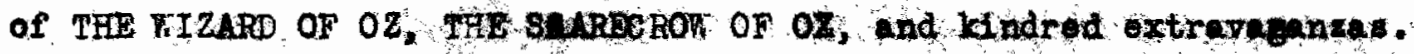

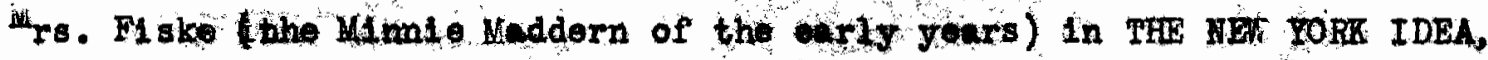

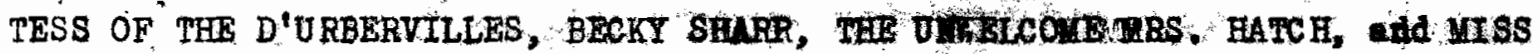

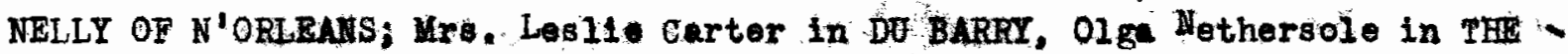
WIFE' OF SCARLI, THE SECOND MHS. TANQULRAY, CNILLE, SAPHO, and ADFEEME LE-

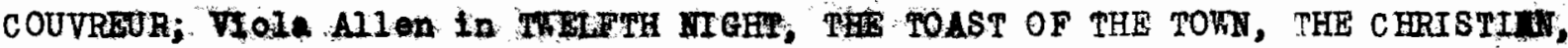
IN THE PALACE OF THE KIMO, and CMBELIME; Virginia Harned in IRIS; Mrs. Patrick Camptell in PYeXLIOA, and THE SRCOHD MRS. TANQUBRW; Ladame Nazimovi in THE DOLL'S HOUSE and BELLA DOMAJ Effte Shannon and Herbert Kelcoy in THE MOTH AND THE FLAME and DY DABGHTER-IN-LAN; John Drew in THE SECOND IN COMMAND, THE MUMY AND THE EDMIMG BIRD, and ROSEMARY; James $\mathrm{K}$. Hrakett in THE WALLS OF JERICHO; Blanche Bates in THE GIRL OF THE GOLDEN WEST - Loujerillo has seen all these during the hatios and these first twenty years of the twentieth conturg.

Besides these mentioned there have been Fanny Davenport in CLEOPAPRA, LA TOSCA, and FEDORA; RIobard Mensflazd in MONSIEUR, DR. JERYL and MR? HYDE, JULIUS CABSAR, BEAU BRUMALI, IVAN THE TEPRIBLT, THE FIRST VIOLIN, and KIHG

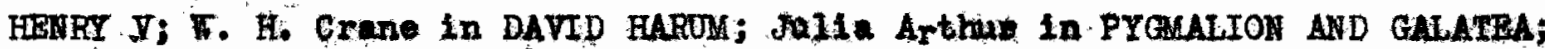
Filiam Collfor in MR. SMOOTH; Elennor Robson in MERELY MARY ANN; and Hiliam Fovorshan in FMPRUDENCE and later in JULJUS CAESAR. Ethel Barmyore ia COUSII KATE, in ALICE SI T-BY-THE-FIRE, in THE OFF CHANC E, or in whatover play sho offers, is always a favorite In Lou isville. John Barrymore who was seen in Loutsville in JUSTICE was first seen in Lou isville with his olster in ALICE SIT-BY-THE-FIRE during the early yens of the century." The members of the Sothern and Larlowe partnership were as popular separately as they waro together. Foul orille saw Julie Marlowe inTEE CAVALIER, WHEN KNIGHTHOOD FAS IN FLOHRR, and FOR BONNIE PRINC B CHARLIE, and E. H. Sothern in RICHARD WOVFLACB, THE ERPI TO THE KING, and THE PROUD PRINCE at different times, 
1.7.

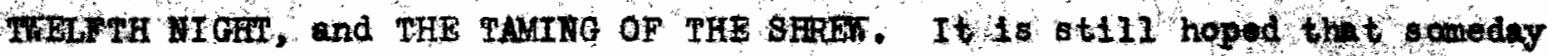

Louisville may see them again.

Loúlsvillo saw Jospgh Jefferson's RIP VAN WHILLE for the hat thme in 1903.

Otis Skinner made a momorable appoaranee at Macauley's with Ade Rehnen in 1903 when those two excellent playors presented THE MERCHANT OF VMIC THE SCHOOL FOR SCANDAL, and the PAMING OR THE SHREF. In 1901 Skinner with Bleanor Robson and Sawh Cowell LeNoyno eppeared in Browning's IN A BALCOWI. Others of Mr. Skinner's playre indiude A SOLDIER OF FORTONE, FHE DUEL, THE HONOR OF THE FAMILY, HAZARRE, FRANCESCA DA RIMIMI, WISTER ANTONIO, and most recont of all AT THE VILLA ROSE.

Loulgvilie long since began to worship at the shrine of David Farfilid, and the ofty almays hastene to do him honor in whatever play he appenrs. It has seen him in THE NOTIONEER, THE MUSIC MASTER, VAN DER DECKEN (which he did not play in New York), and IN THE RETURN OF PETREI BRIM.

Heal drame lovers in the ofty are lways glad to relcome each season Robert Bruee Mantell in his repertolre of Shdkespertan plays. Mr. Mantell la now the only actor who ptesent the fortudable number of character which he plays. Daring tho pat season (1920 - 21) the cfty saw another actor in Sha boporoan pleys, Fritz Leiber, to whom the country look to carry on the traditions of the greatest drame.

Maude Adans is one of the greatest farorttes Loulsville knows, and the cit hes seen her in practically all of the plays in which she has been

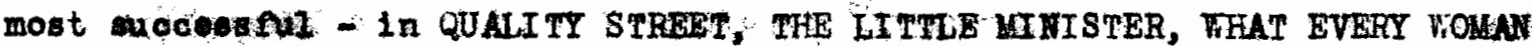

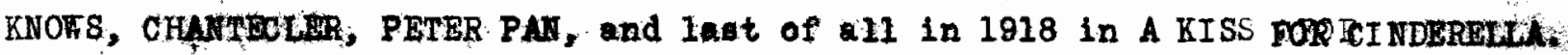

the $118 t$ of aetors who have appexied in Louisville might be extended into the hundreds and yet not include 11 those who have given pleasure to theatre avdleneos in tho atty. Betrdes Mary Inderson and Saloonah Fetter

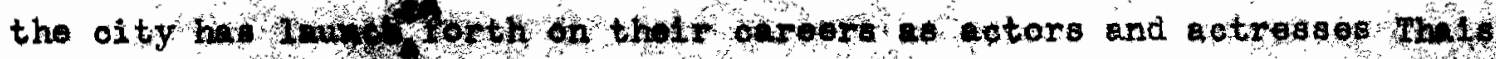




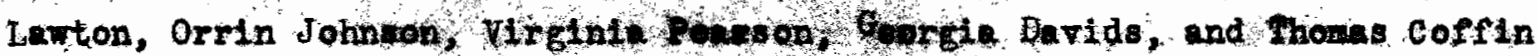
cooke, and within the vory recont rears, Burberguliton.

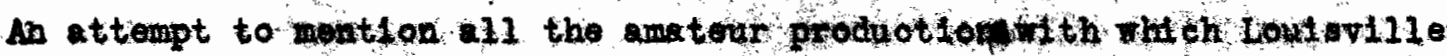
has been honored would meet Wth the ano wount of oucoess as atterpt to

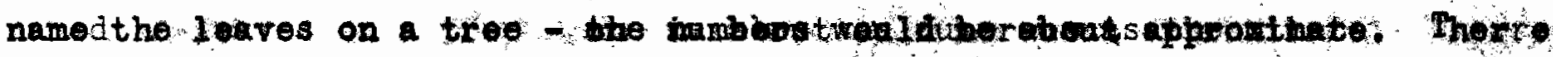
have been the usual sohool plays, somo of thom rory worthy attempts for and teurd and the perfommoes by the many drametic organtzations which bare cone into being and in a few years pased out again. As samples of tamateur performanges of the oariy years of the extary, one proth mention the production of CAIISAY at the Auditorium in 1904, for the beneftt of the Children's Free Hospital. Miss Edith Terry, Mrs. Carrle Rothechild Sepinsky. Mr. Frank Root, Miss Hattie Eckels, Mr. Fulton Manderilae, and Mr. RIdgewey Gobhart were prominent in cest of that play. In 1904 a spetacular production of ALICE II FONDERLARD with many children in the cast wa given.

Among the misical organteations in Loulavilie should be mentioned tho Philharmonic Society, the Liederkranz, the Loulavillo Male choms (fow under the directbohts of H. Oerl shackleton), and the Loul svillo Quintet Club.

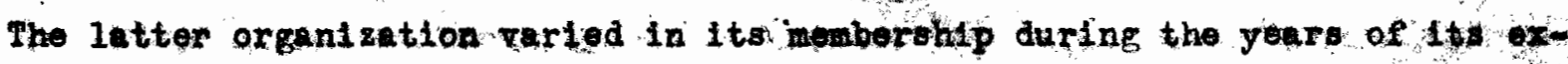
Istence, but 1ts lateat menbers were Mrs. J. E. Thitneg Mur add Mrs. Motor Fadolf, Hr, Charles Letzlor, and Mr, Karl sahidt. Professional singers and players of misic have been numeraus - Kubolik, Paderevski, Elman, Souse and ho band, John Haccormack, CIIL-Curcl, Totrazinni - Louisvillo has heard thom 11 .

Dramatio organizations aotive at the present time in Loui ville are the I. M. H. A. Players, who give their plays in the auditoriun of the Toung

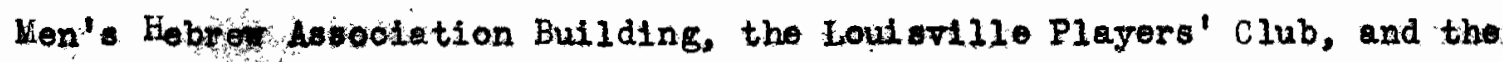
Univerabt toplowisville player - to mention the most active and prominont of the anteur players.

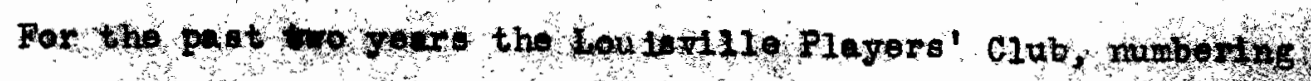




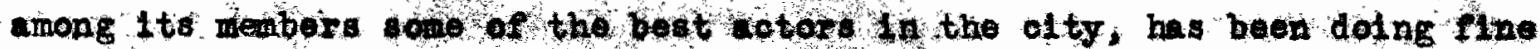

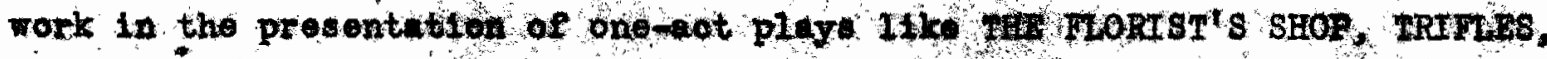

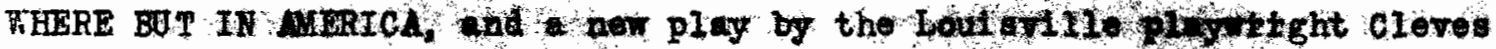

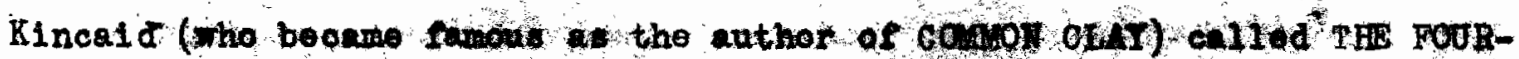
FUSHERS.

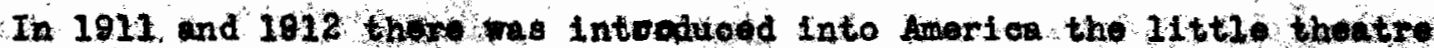
movenent, so-celled. The lien at the foundilt on of this movenent is experimentetion In acting, in the staging of plitys, and in playmightlag* The little theatres are not oomeroinl theatres. 'hey are ostablishod from "Iove of druma and nót fron love of gain" (Constance D' hroy Mactay)- The Littie Theatre in Amertox - Fages 1 and 2.) By many porsons the 11ttle theatres are thought to contafin the selvation of the drame in Amerion. Our big theatres are generally all managed on comercial basis with their grestest thought oentiering upon the idea of making a great deal of motrey. The iftelo theatiog care for the dreme itself, and with this thoughtin mind, they attempt to produce and to present the best that they know in the ofl and in the new dramitio literature.

Louf ovilie has had little theatre sinee 1914, although many pereone 1. the oity are just beginning to be amere of $1 \mathrm{ts}$ extistencer Ifke almost

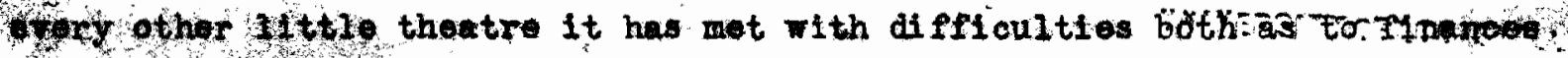
and equthent during the entire course of its Mio. The littlo theatro in Lout svi110 is the Dranatic Horkehop of the Untrorsity of Lou is ville Players

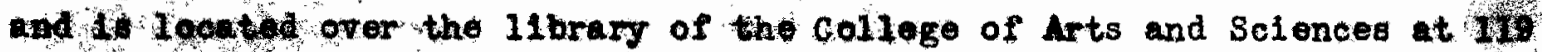
Wost Bropayts tho-Univerdty of Loulanille had a dramatic elub several jours before the littio theatre began, but it was not until the players under the drection of Mr. Boyd Martin in 1914 thet thoy did any real 116t1e theatre work. It is customary in the spring for the Players to give ievowi performades of a plag at Macaliey's Theatre, but the remainder of thetw plote are perfertied at the horkshop. Some of the nost notable productions whioh 


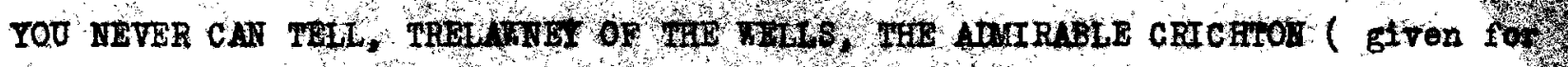

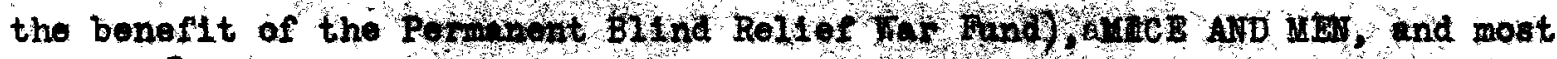

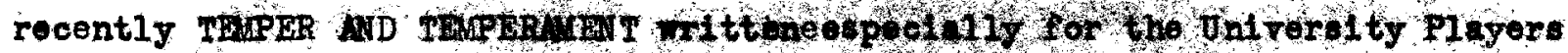

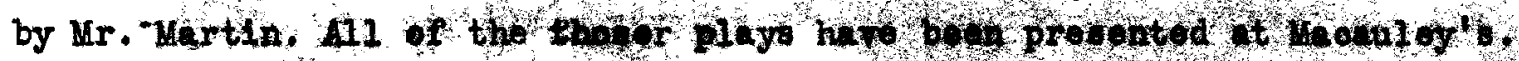

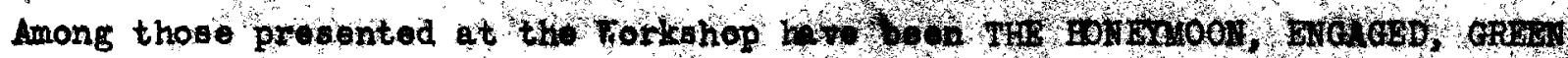

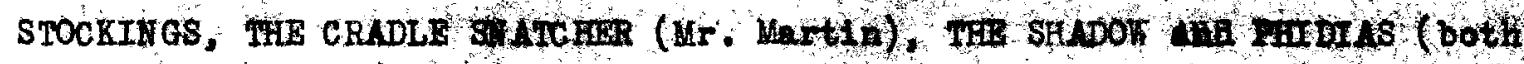

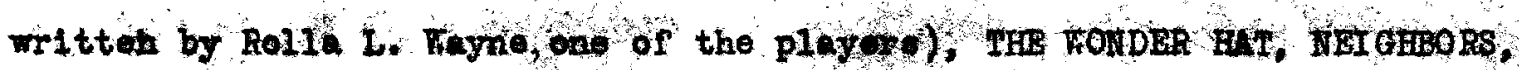

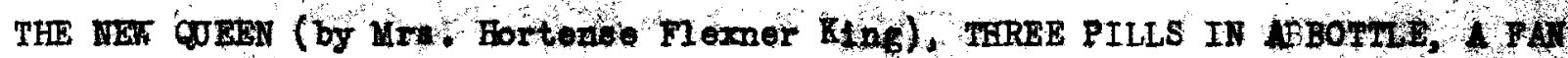
AND TKO CANDLEWTICKS, SUPPRESSED DESIRES, THE BISHOP'S CANDLE-STICKS, FAMT AND THE SERVANT PROBLAM, THE DEAH DERARTED; and the UGLY DUCKLING (Mr. Mattin.) In June, 1920, the players presended in the gerdens of Lieutenant-Goverator Ballard 1 MIDSUMBER NIGH'S DREA and repoated the performance on the follombrg inight in Tyler Park.

The Untiersity of Loul afilio Players' Drematic Morkshop works on the belief thet the most effective meari bef.. Iodriting ..... all the prinoiples of the drama is to produco plays, and the mombers of the dramatio cless do all the work, aside from the direoting, of the plays. At times nembers of the oldes dirot shont pingo for crttibtim in tho oless, and one-act play des sonotimes written es part of tho regina olwo work. The city belloves in

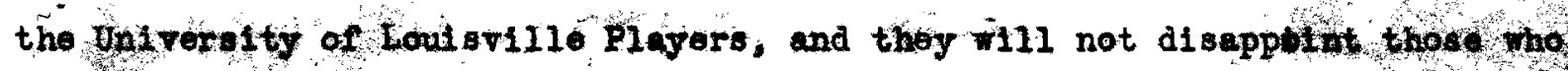
have oth in them.

It is the alm of all the amateurs in Loulsw1110, espectally may this be satd of the Players' $C l u b$ and the University players, to present to the elty the best that can be offered in what is new, and the memorable and worthWhilo plays of tilo pest. After several yearo the city has learned to look to its $11 t+10$ theatro for that is good in plays, in ecting, and in stage. rettings executed with simplicity and beauty. It has been the task of the amateurs in Loatevilie to foster in the of ty the love for real drame, for

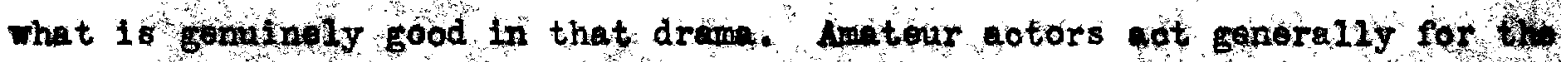

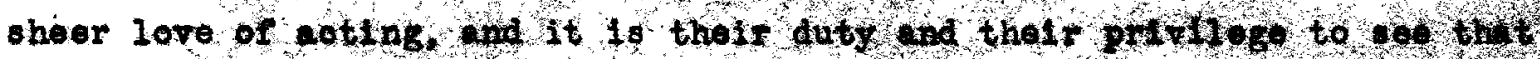


they are the medun through whoh the dol to for genuinely good plays ig kept

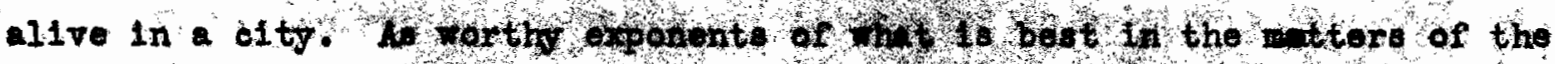

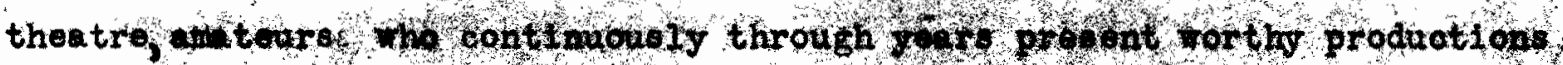

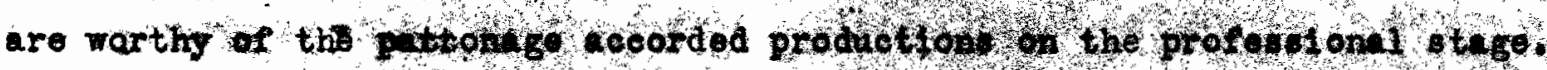

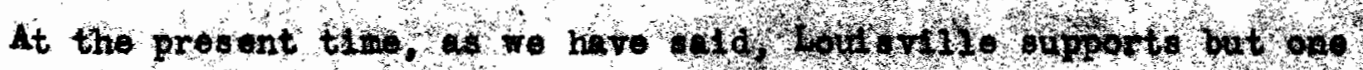

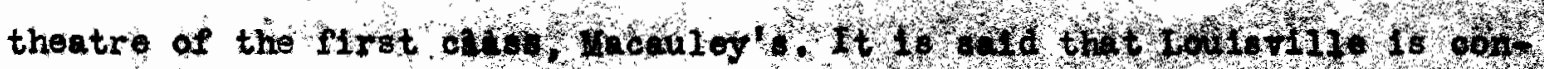

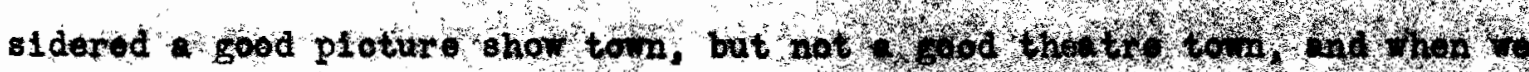

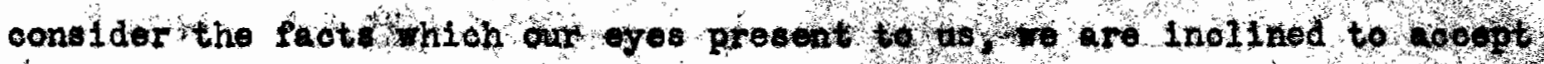

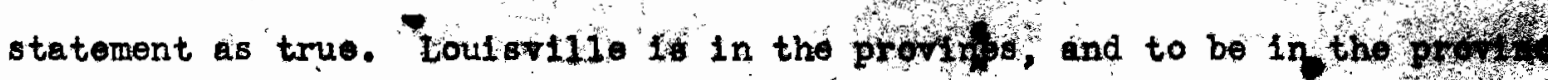
theatrically mans that she mot eithor walt to seo new York productions of eral soasorafter they have first been produced, and the company it sent on tour, or see the plays giren by one of the second companies sent out to $\mathrm{dot}^{\mathrm{y}}$ the country outside New York." The mer $\operatorname{con}$ stage during the past years hat been flooded mth meficel oomedies, and the effect is seen in the productions offered in all the larger ofties. It seems to the reader of theatrical notloos thet fully half of the time of the seasons is mide up of the presentation of these singing and danoing affairs - song and dances strang togother on an almost non-existent plot and decked out with beintiful scenery, beautiful girlo, and oxquisite $11 \mathrm{ght}$ ing effeots...

There are still real lovers of the drame at its best in Laldollog

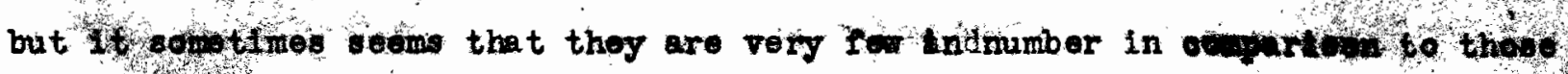
Who flock thoughtlessiy to the theatro to bee a msical comedy or to the plotuto. show to seo their favorite movie otur in whatover filin he happens to be eppearing.

Ths state of affairs is to be doplored, and it is to be hoped that it will soon be found that Louisvil1 oan support a atock compeny which will give to those who love drame for ita own sake an opportunity to sed productions which are adequate and worthy. Indianapolis ech oumer enjoys a season $\mathbb{t}$ ith the Stuert Falker Flayers, and there is reeson to hope that soon Loulsvilige may also enjog a gevon flth these or similar playors. 
It is thought by thord tho are lnterobted In mattars thoutrieal that

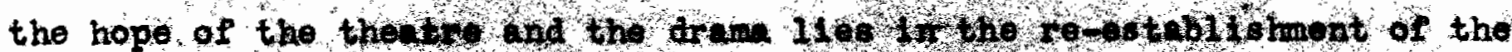

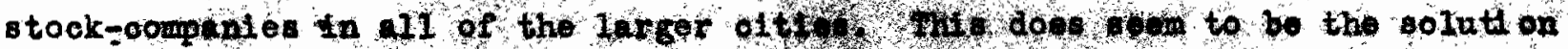

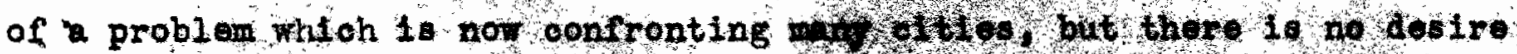

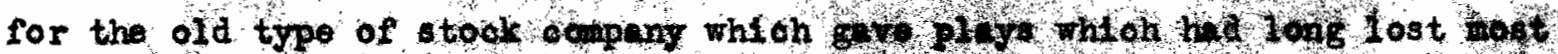
of tholr popularity, but for oompanted oftows the boo plos of the day. well mounted and rell acted.

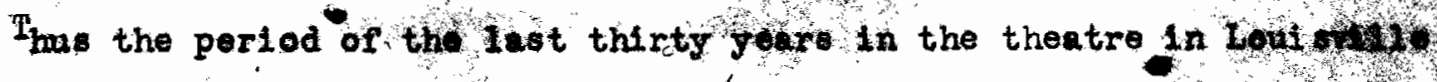
has seen the decline of the thoutre, tho passing of the old stook opuputtoy and stunds at the beginning of whet won hope is to be new ora of fortothoss for the dram in smerica. Louierilie in these years hasintubean diffotobt from the taet majority of other citios in ho country. Her theatrical hoteny durlng to period might be duplicated almost anywhere. Some writer blume the picture shows, and others plece the bleine upon the spirit of oomarelalisif which entered into the business alde of the thentre during the nineties and almost orushed the lifen an which shauld be waintained only on the highest basis of artistry.

Whatever may be the cafse for the deoline, it is evident now that the publ10, even the tired business man for mom so many of the light imosstolod masionl shows are ould to be made, is becoming surfettod wth too mudh of the vory thing that was made to pleese its fancy or more probably tho fancies of thoae who maintain that they lonow what the public wants. 


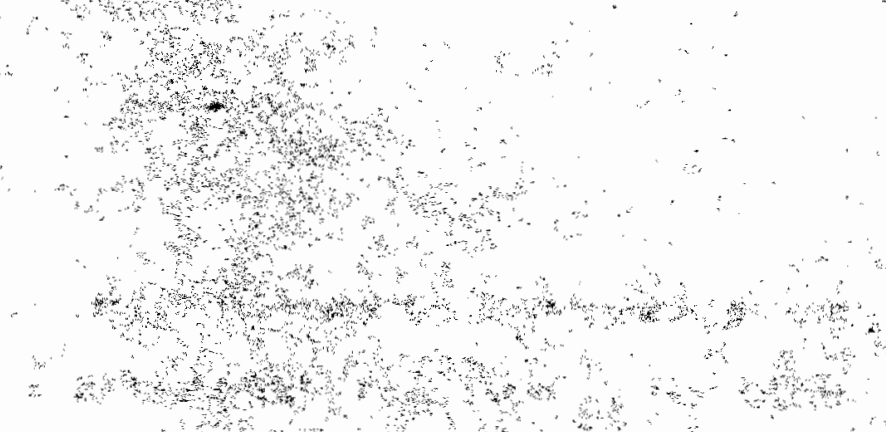

\section{C $\mathbf{A P T E R}$ R.}

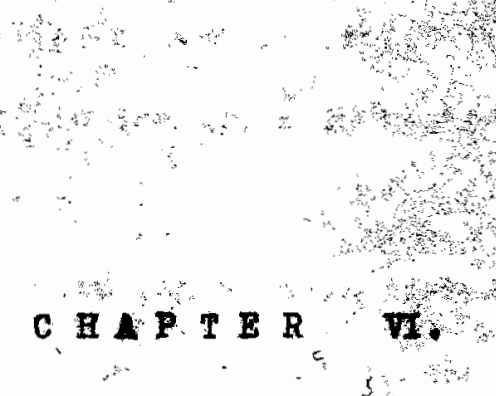

LOOKING TOWADD IHE TUTORE.

$\because x^{\prime}$
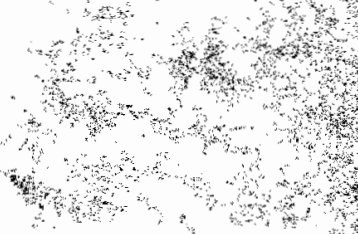

3. $+3 \times+3$ 
C10.t?

LOOKTIO TONIRD THE IUTORE.

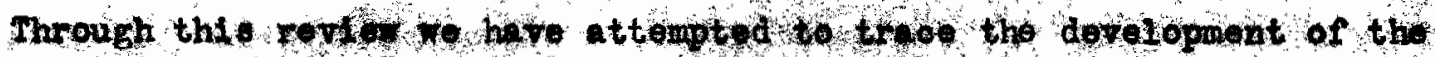

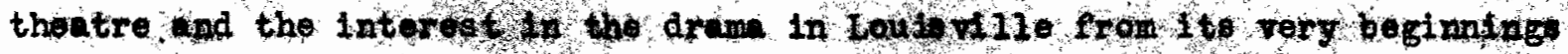
Sunt11 the prosent tint

It Is coumon cogusatlon brought agand historians in theatrioal matters that they alweys extol the pest to the detrinent of the present. yon of the latter part of the ninetenth ontury praised the eally part of tho obo tury, and that, too, with Edwin Booth, Medjotia, Lawrenoe Barrott, and Hury Inderson appearing on the tego sut no recorder of futs tomday can be criticized harshy if he feels that at the present time much of the glory hes departed fron the thoatre.

Loulovilio's record in the theatro during the lest contury was a brillient ore. A far smalier eity than it is now, it edequately supposted tro, threo, and even forr theatres offering the best productions of the day, exclusire of the variety thentro, To-day sho supports one real theatre, and her populati on mumbers wore than two handred and sevienty thousand.

The attilude of the clty toward the theatre was always most friendly.

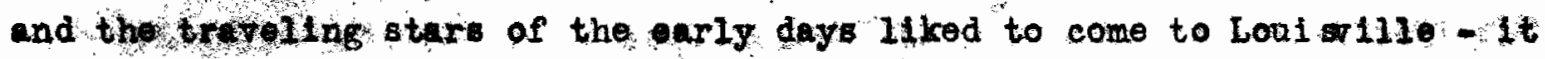
was knom to be a good plece in whoh ta popform. As far back as tho flitiot. Louis rlite audiences were cocused of coleness and an attitude toward the actors on the (tage whoh was very hard for the performers to overoome. But the reatly worthy players never found Lou s ville audiences oold or lacking in enthasiam, and It seoms sufe to say that the theatro-going public of tho city usually gecorded honor where honer was due and rewarked the actors accordo ing to what it comsidered to be their merits.

Tho stodr tompanios in other difs de productions of their om, ind

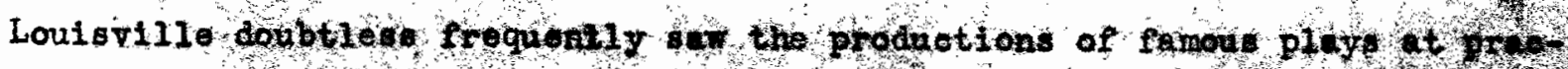




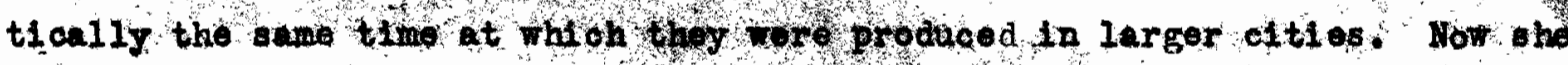
watts unt1l the big mangors ero ready to bod olt coupanios, or af ahe

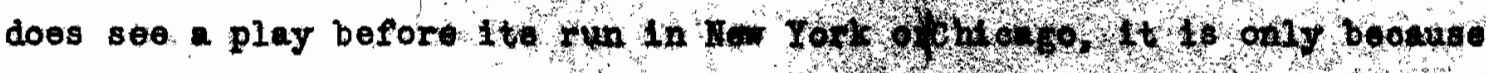

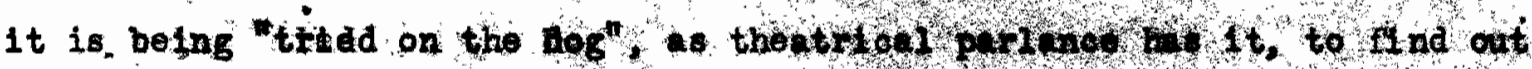
whether it wil bear prosentation in for $70 \mathrm{rl}$ or not:

The future, however, holds brighter prospots for the theatre then

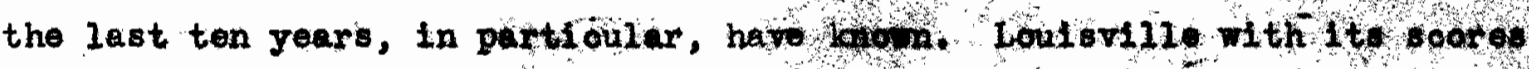
of pleture theatees, its vaudeville and its burlesque shows, and 1 to ono legitimate theatre looks toward the cooming years for a return to har glowes of history. The present generation of theatre-goers has been tatinditnam matters of the stage when the art of the theetre has been at $10 \mathrm{w}$ obb, but pren the chlldren in the cohools tomday are learning wa to expect in good play, how to mite one, and how to not in it besides how to produce 1t. Surely from men and romen thus tratried and equippod we may look for good thinge. In defense of the present. generation it mat be suld that anong the patrons of the thentro as it is who are often blamed for bringing the theatre to the state in whoh it is, when they have but accepted what money-getting protucess haye offered - among those patrons there are many Tho infinitely prefer a performance of DEAR BRUTUS to one of FIDDLERS THREs,

Lyman Abbott says that the threefold service of the theatre is to fumbindusoment, rest, and inopiration (Tho Outlook - April 20, 1921 - Pago 634). Loulstilie theatres of the past have rondered that threefold servies. and me on hope that the day is coming when the theatre will again realige and fulfill its mision in the community. Loulsville, then, looks to the future for better days in her theatre, and we dere to say that both the future and the botter days are coming soon. 


(El)11ography conoludod)

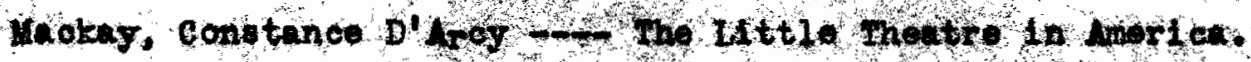
The outioot.

- Poter, Robert -...-.--Hiatory of Fayette 0 canty, Kontuoky. Pitou, Anguatis -.-.- Muters of the show

Ranck, Goorgo T. -... History of Lexington

Towse, John' Runkin - - Stxty Yours of the theatre.

Sohelling, Felix E. -.-- English Drama.

Falkley, Arthur Bingham -..-: Drama and Life.

Vinter, Filiiem -...- Life and Art of Edwin Booth.

'. Winter, William -- - Life and Art of Joseph Jefferson.

Winter, William -ma- Stage Life of Mary Anderson.

Finter, Filliam -...- Shikespeare on the Stage.

Finter, Filitam -...-. The Fiallet of Fime.

Finter, Wiliam -...-. Shadows of the Stage.

Vinter, Tilliam -..-- Vagrant Mewories.

The New International Encyclopedie. (Volume 22)

The Eneyclophedie Brittanica (Volume 26)

Pregram Hook belonging to Mi Bs Ida Radolf. 